\title{
Correlação entre a polarização da luz emitida e a morfologia de filmes luminescentes de poli (fenileno vinileno) e derivados.
}

\section{Thiago Cazati}

Dissertação apresentada à Área Interunidades em Ciência e Engenharia de Materiais, da Universidade de São Paulo, para obtenção do título de Mestre em Ciências e Engenharia de Materiais.

Orientador: Prof. Dr. Roberto Mendonça Faria

São Carlos - 2003

USPAFSC/SBI 
Cazati, Thiago.

"Correlação entre a polarização da luz emitida e a morfologia de filmes luminescentes de poli (fenileno vinileno) e derivados".

Thiago /Cazati - São Carlos, 2003

Dissertação (Mestrado) - Área de Física da Universidade de São Paulo, 2003 - Páginas: 88

Orientador: Prof. Dr. Roberto Mendonça Faria.

1. Fotoluminescência; 2.Filmes de PPV; 3. Polarização.

I. Título 
Aos meus pais, Adalberto e Marli, à minha companheira Bruna

e a todos que contribuíram para a realização deste trabalho. 
UNIVERSIDAdE dE SÃo PAULO

Ciência e Engenharia de Materiais

Caixa Postal 369 - CEP 13560-970 - São Carlos-SP - Brasil

Tel: (0xx16) 2739589/ Fax: (0xx16) 2739777

e-mail: wladerez@if.sc.usp.br

MEMBROS DA COMISSÃO JULGADORA DA DISSERTAÇÃO DE MESTRADO DE THIAGO CAZATI, APRESENTADA À ÁREA INTERUNIDADES CIÊNCIA E ENGENHARIA DE MATERIAIS, UNIVERSIDADE DE SÃO PAULO, EM 23/05/2003.

COMISSÃO JULGADORA:

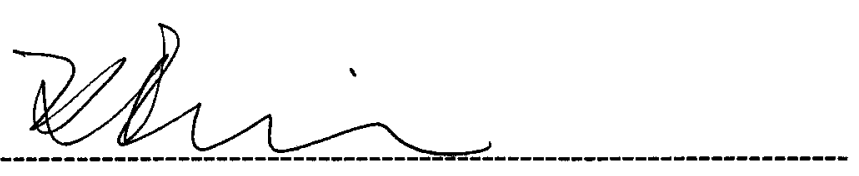

Prof. Dr. Roberto Mendonça Faria ( Presidente) - IFSC-USP

Jum Wib jambon ato

Profa. Dra. Teresa Dib Zambon Atvars - UNICAMP

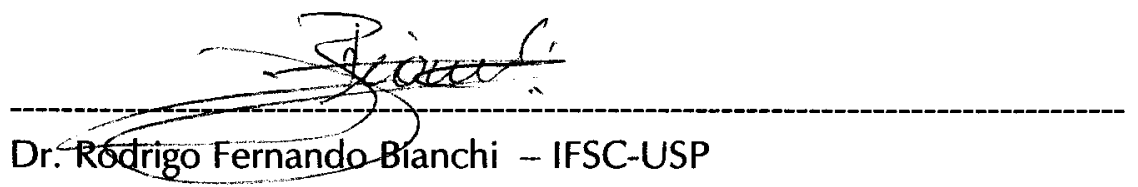




\section{AGRADECIMENTOS}

- Ao Prof. Roberto M. Faria, meu orientador, que teve um papel importantissimo em todas as etapas deste trabalho, pela orientação e confiança em mim depositada.

- Ao prof. Francisco Eduardo G. Guimarães, "São Francisco", em disponibilizar não apenas o laboratório, como todo seu tempo e seu conhecimento nas discussões e ensinamentos. Pela amizade e bom humor.

- Ao Prof. Alexandre Marletta (UFU), pela inestimável colaboração no trabalho, amizade e aos valiosos conselhos.

- À minha companheira Bruna, pela paciência, apoio e motivação nos momentos difíceis deste trabalho. Pelas discussões e por corrigir infinitas vezes a minha dissertação.

- Aos amigos e técnicos Níbio, Bertho, Ademir e a secretária Rosangela, pelo apoio técnico e pela valiosa ajuda com os serviços burocráticos.

- Aos meus companheiros de luta do Grupo de Polimeros: Lucas (Japa), Xuxa, Clarissa, Patrícia Bueno, Patrícia Stracks, Tubinho (Felipe), Luciana, Sarita, Maurício, Carla, Letícia, Silmar, Tony, Ubaldo, Fernadinho, Célio, Edvaldo, Vicente, Miguel, Kid Vinil e ao Flitz. Meus especiais agradecimentos ao Rodrigão pela paciência e transmissão de conhecimento e ao David, meu companheiro de sala, pela companhia e colaboração.

- Aos meus pais, por terem acreditado em mim e às minhas irmãs Thelma e Thais pelo carinho, paciência e compreensão.

- A todos os professores do Grupo, pelas discussões e apoio.

- À Fapesp pelo essencial apoio financeiro. 


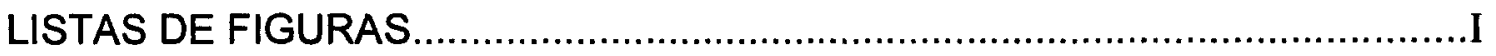

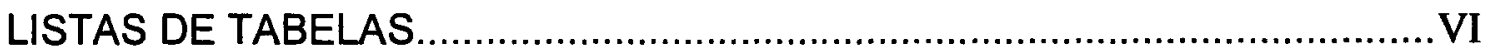

LISTAS DE ABREVIATURAS E SÍMBOLOS................................................III

RESUMO

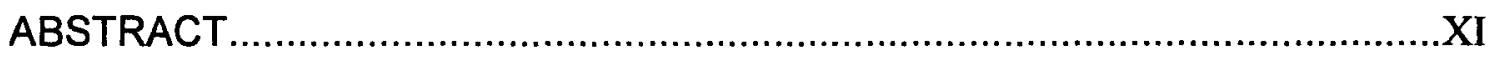

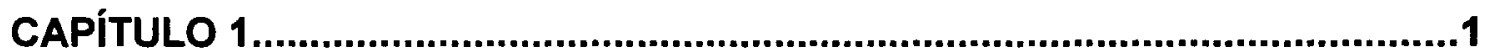

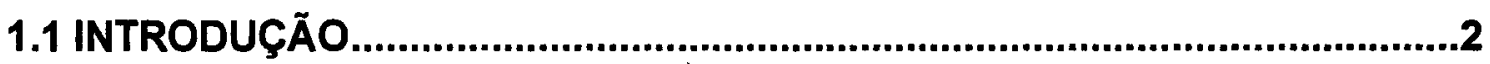

CAPÍTULO 2

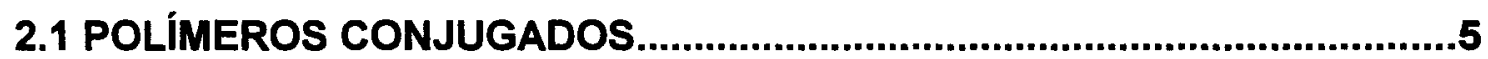

2.1.1 Estrutura eletrônica dos Polímeros Conjugados........................................................7

2.1.2 Absorção e emissão em Polímeros Conjugados...................................................9

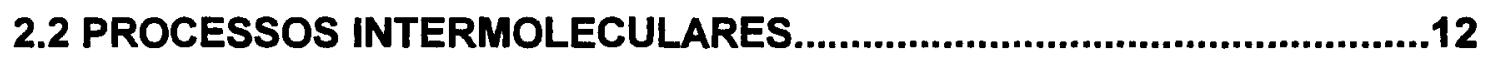

2.2.1 Mecanismos de transportes em macromoléculas.................................................12

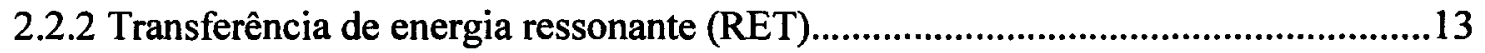

2.2.3: Transferência de energia (Teoria de Förster).....................................................16

2.2.4 Transferência de energia (Processos Complementares)......................................21 


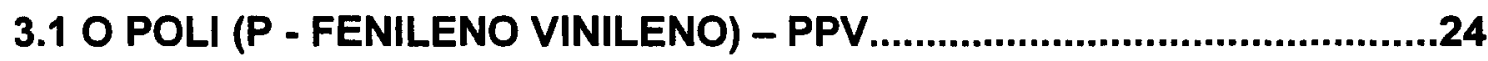

3.2 SÍNTESE QUÍMICA E PROPRIEDADES ÓPTICAS DO PPV.....................24

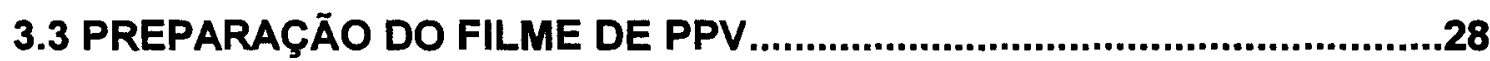

3.3.1 Método Casting....................................................................................................28

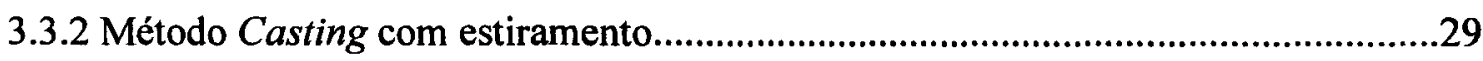

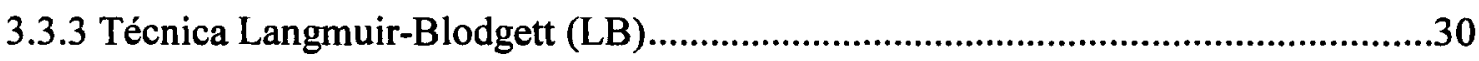

3.3.4. Técnica Spin-Coating (SC).................................................................................3

3.3.5. Técnica Self - Assembly (S.A) com estiramento......................................................34

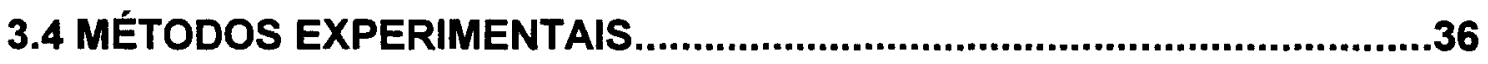

3.4.1 Espectroscopia de Absorção Óptica Polarizada......................................................37

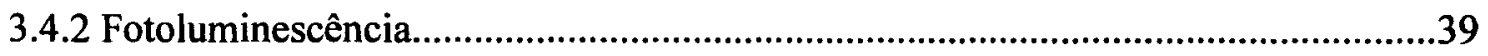

3.4.3 Determinação da Polarização da Luz Emitida..........................................................41

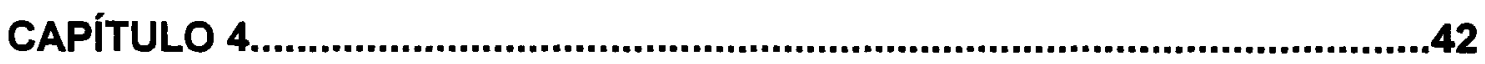

4.1 PROPRIEDADES ÓPTICAS DOS FILMES DE PPV...................................43

4.1.1 Propriedades Ópticas de Filmes de Casting - PPV................................................43

4.1.2 Propriedades Ópticas de Filmes de Spin - PPV..................................................50

4.1.3 Propriedades Ópticas de Filmes de Casting - PPV Estirado....................................55

4.1.4 Propriedades Ópticas de Filmes de LB - PPV..................................................61

4.1.5 Propriedades Ópticas de Filmes de Self-Assembly (S.A) Estirado...........................66

\subsection{MECANISMO DE TRANSFERÊNCIA DE ENERGIA OU CARGA NOS FILMES DE PPV.

4.2.1 Mecanismo de Transferência de Energia ou Carga para Filmes de PPV obtido pelo Método Casting. . .72

4.2.2 Mecanismo de Transferência de Energia ou Carga para Filmes de PPV obtidos pela Técnica Spin-Coating. 
4.2.3 Mecanismo de Transferência de Energia ou Carga para Filmes de PPV Estirados obtidos pelo Método Casting............................................................................................73

4.2.4 Mecanismo de Transferência de Energia ou Carga para Filmes de PPV obtidos pela Técnica Langmuir-Blodgett (LB)...............................................................................74

4.2.5 Mecanismo de Transferência de Energia ou Carga para Filmes de PPV Estirados obtidos pela Técnica de Self-Assembly (S.A).................................................................75

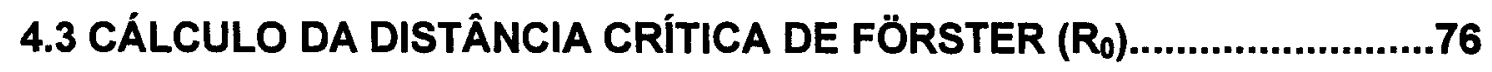

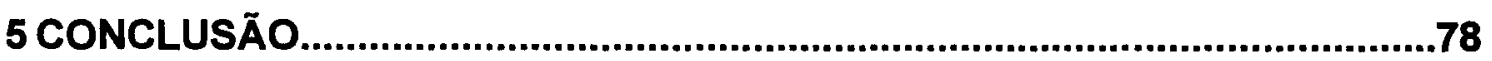

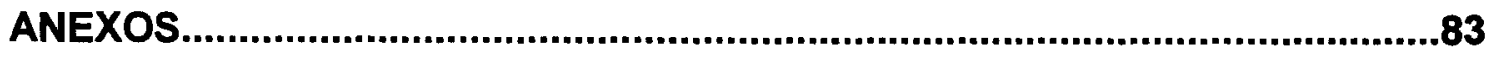

REFERÊNCIAS.....................................................................................8 
Figura 2.1: Distribuição de probabilidade eletrônica do Butadieno $\left(\mathrm{C}_{4} \mathrm{H}_{6}\right)$. (a) Orbitais $\sigma$ localizados, paralelos ao plano da molécula; (b) Orbitais $\pi$ não localizados, perpendiculares ao plano da molécula.

Figura 2.2: (a) Ilustração esquemática do diagrama de energia na representação de coordenadas. (b) Estrutura eletrônica do PPV, as letras d e d* indicam estados localizados e não localizados, respectivamente. .7

Figura 2.3: Variação da energia de Gap $\left(E_{g}\right)$ em função do tamanho de conjugação ( $0 \leq$ $\mathrm{n} \geq 16$ ) para o oligômero de PPV. . .8

Figura 2.4: (a) Representação conformacional da quebra de conjugação de um copolímero causada por defeitos estruturais e conformacionais. (b) Ilustração do modelo físico envolvendo de segmentos conjugados de diferentes tamanhos, separados por segmentos não conjugados.

Figura 2.5: Esquema energético do acoplamento elétron-fônon. Inicialmente tem-se o estado eletrônico a (HOMO) e b (LUMO) que são somados a energia potencial vibracional e representados nas coordenadas normais de vibração da macromolécula.

Figura 2.6: Processo de absorção e emissão entre estados moleculares com acoplamento elétron-fônon. 11

Figura 2.7: Diagrama de níveis de energia simplificado da transferência de energia ressonante. D refere-se ao doador e A ao aceitador, os asterísticos denotam estado excitados.

Figura 2.8: A eficiência da transferência, E, em função da distância doador - aceitador, $R(A)$, e em função da distância crítica de transferência, $R_{0}(B)$, de acordo com a equação (2.8).

Figura 2.9: (1) Dinâmica da migração de energia via tunelamento (E) entre segmentos conjugados ao longo de uma cadeia polimérica conjugada e (2) entre cadeias conjugadas. .21

Figura 3.1: Rota de preparação da solução aquosa do precursor do PPV antes da conversão térmica.

Figura 3.2: Esquema do processo de conversão do PPV. (i) Esquema da rota convencional de tratamento térmico à $300^{\circ} \mathrm{C}$ para obter PPV. (ii) Adição do DBS ao PTHT com a formação de um copolímero estatístico, tendo o tetrahidrotiofeno das unidades monoméricas complexado com o contra-íon DBS (x) e $\mathrm{Cl}$ (y). (iii) Processo de 
eliminação do grupo de saída tetrahidrotiofeno complexado com o contra-íon DBS a baixas temperaturas $\left(115^{\circ} \mathrm{C}\right)$ há tempos rápidos $(3 \mathrm{~min})$.

Figura 3.3: Curvas de absorção (verde) e de emissão (fotoluminescência) (azul) do PPV, mostrando as regiões de alta absorção do polímero.

Figura 3.4: Esquema utilizado para a obtenção de filmes de PPV pelo método Casting.(1) A solução é depositada sobre o substrato e (2) aquecida á $200^{\circ} \mathrm{C}$ para que ocorra a conversão da solução precursora em PPV já na forma de filme. .28

Figura 3.5: (a) Aplicam-se forças de sentido contrários numa mesma direção nas extremidades de uma fita de Teflon ${ }^{\circledR}$ contendo a solução do polímero precursor até obter o estiramento desejado. (b) Com o estiramento da fita as moléculas de polímero depositadas sobre ela se organizam de modo a se orientarem na direção da força aplicada. 29

Figura 3.6: Ilustração de um sistema KSV-5000 (cuba de Langmuir) para formação de filmes de Langmuir

Figura 3.7: Tipos de deposição de filmes LB

Figura 3.8: Ilustração da isoterma de pressão 32

Figura 3.9: Estágios de formação de um filme por Spin-Coating. .34

Figura 3.10: Esquema da formação dos filmes por S.A. No final do ciclo tem-se a formação de uma bicamada com espessura controlada a partir do tempo de imersão nas soluções.

Figura 3.11: Sistema óptico do espectrômetro Hitachi U-2001 para a medida de absorção óptica polarizada. 38

Figura 3.12: Esquema do aparato experimental para medida de fotoluminescência polarizada e em função da temperatura

Figura 3.13: Esquema para determinar as propriedades da polarização da luz emitida.

Figura 4.1: Medidas de absorbância polarizada à temperatura ambiente para um filme de PPV obtido pelo método Casting. $A_{/ /}$e $A_{\perp}$ são as absorções nas direções de polarização da luz incidente paralelamente e perpendicularmente ao eixo vertical do filme, respectivamente 
Figura 4.2: Espectros de fotoluminescência para comprimento de excitação de $458,0 \mathrm{~nm}$ em função da temperatura da amostra Casting - PPV. As setas indicam o pico de PL para as temperaturas de $9 \mathrm{~K}$ e $180 \mathrm{~K}$ e os respectivos comprimentos de onda. Em detalhe a dependência da intensidade integrada da PL do filme Casting com a temperatura. .45

Figura 4.3: Esquema experimental para medida de fotoluminescência polarizada utilizando duas configurações de polarização da luz incidente $\left(\mathrm{P}_{1}\right)$ e para 0 analisador $\left(\mathrm{P}_{2}\right)$ .46

Figura 4.4: Espectro da fotoluminescência polarizada para o filme de PPV obtido pelo método Casting à temperatura de $60 \mathrm{~K}$ 47

Figura 4.5: Medida da polarização da luz emitida pelo filme de PPV obtido pelo método Casting. O Gráfico mostra a intensidade da luz emitida normalizada em função do ângulo do analisador $\left(0^{\circ}\right.$ a $\left.360^{\circ}\right)$ para as duas direções da polarização da luz de excitação, $\mathrm{P}_{1}(/ /)$ paralelo e $\mathrm{P}_{2}(\perp)$ perpendicular ao eixo vertical da amostra.

Figura 4.6: Medidas de absorbância polarizada à temperatura ambiente para um filme Casting de PPV estirado 2 vezes do seu tamanho original. $A_{/ /}$e $A_{\perp}$ são as absorções nas direções de polarização da luz incidente paralelamente e perpendicularmente à direção de estiramento do filme, respectivamente. .51

Figura 4.7: Espectros de fotoluminescência para comprimento de excitação de $458,0 \mathrm{~nm}$ em função da temperatura para filme Casting de PPV estirado 2 vezes do seu tamanho original. As setas indicam o pico de PL para as temperaturas de $10 \mathrm{~K}$ e $180 \mathrm{~K}$ e os respectivos comprimentos de onda. Em detalhe a dependência da intensidade integrada da PL do filme Casting de PPV 2 vezes estirado em função da temperatura. .52

Figura 4.8: Espectro da fotoluminescência polarizada para o filme Casting de PPV estirado à temperatura de $60 \mathrm{~K}$ para diferentes configurações da polarização da luz de excitação $P_{1}\left(\lambda_{\text {ex }}=442 \mathrm{~nm}\right)$ e de emissão $P_{2}$. 53

Figura 4.9: Medida da polarização da luz emitida pelo filme de PPV obtido pelo método Casting estirado 2 vezes do seu tamanho original. $O$ Gráfico mostra a intensidade da luz emitida normalizada em função do ângulo do analisador $P_{2}$ num intervalo $0^{\circ}$ a $360^{\circ}$, para as duas direções da polarização da luz de excitação, $P_{1}(/ /)$ paralelo e $P_{2}(\perp)$ perpendicular à direção de estiramento.

Figura 4.10: Medidas de absorbância polarizada à temperatura ambiente para um filme de PPV preparado pela técnica Spin-Coating. $A_{/ /}$e $A_{\perp}$ são as absorções nas direções de polarização da luz incidente paralelamente e perpendicularmente à direção de estiramento do filme, respectivamente. 56

Figura 4.11: Espectros de fotoluminescência para comprimento de excitação de 458,0 $\mathrm{nm}$ em função da temperatura para filme de PPV obtido pela técnica Spin-Coating. As 
setas indicam o pico de PL para as temperaturas de $9 \mathrm{~K}$ e $180 \mathrm{~K}$ e os respectivos comprimentos de onda. Em detalhe a dependência da intensidade integrada da PL em função da temperatura.

Figura 4.12: Espectro da fotoluminescência polarizada para o filme de PPV obtido pela técnica Spin-Coating à temperatura de $60 \mathrm{~K}$, para diferentes configurações da polarização da luz de excitação $P_{1}\left(\lambda_{e x}=442 \mathrm{~nm}\right)$ e de emissão $P_{2}$ 58

Figura 4.13: Medida da polarização da luz emitida pelo filme de PPV obtido pela técnica Spin-Coating. O Gráfico acima mostra a intensidade da luz emitida normalizada em função do ângulo do analisador $\mathrm{P}_{2}$ num intervalo $0^{\circ}$ a $360^{\circ}$, para as duas direções da polarização da luz de excitação, $P_{1}(/ /)$ paralelo e $P_{2}(\perp)$ perpendicular à direção do eixo vertical da amostra.

Figura 4.14: Medidas de absorbância polarizada à temperatura ambiente para um filme de PPV preparado pela técnica Langmuir-Blodgett (LB). $A_{/ /}$e $A_{\perp}$ são as absorções nas direções de polarização da luz incidente paralelamente e perpendicularmente à direção de imersão do filme, respectivamente.

Figura 4.15: Espectros de fotoluminescência para comprimento de excitação de 458,0 $\mathrm{nm}$ em função da temperatura para filme de PPV obtido pela técnica LB. As setas indicam o pico de PL para as temperaturas de $9 \mathrm{~K}$ e $180 \mathrm{~K}$ e os respectivos comprimentos de onda. Em detalhe a dependência da intensidade integrada da PL em função da temperatura.

Figura 4.16: Espectro da fotoluminescência polarizada para o filme de PPV obtido pela técnica LB à temperatura de $60 \mathrm{~K}$, para diferentes configurações da polarização da luz de excitação $P_{1}\left(\lambda_{\text {ex }}=442 \mathrm{~nm}\right)$ e de emissão $P_{2}$ .64

Figura 4.17: Medida da polarização da luz emitida pelo filme de PPV obtido pela técnica Langmuir-Blodgett (LB). $O$ Gráfico acima mostra a intensidade da luz emitida normalizada em função do ângulo do analisador $\mathrm{P}_{2}$ num intervalo $0^{\circ}$ a $360^{\circ}$, para as duas direções da polarização da luz de excitação, $\mathrm{P}_{1}(/ /)$ paralelo e $\mathrm{P}_{2}(\perp)$ perpendicular à direção de imersão da amostra. .65

Figura 4.18: Medidas de absorbância polarizada à temperatura ambiente para um filme de PPV obtido pela técnica S.A. e estirado 2 vezes do seu tamanho original. $A_{/ /}$e $A_{\perp}$ são as absorções nas direções de polarização da luz incidente paralelamente $e$ perpendicularmente à direção de estiramento do filme, respectivamente. .67

Figura 4.19: Espectros de fotoluminescência em função da temperatura para filme de PPV obtido pela técnica S.A. e posteriormente estirado. As setas indicam o pico de PL para as temperaturas de $9 \mathrm{~K}$ e $180 \mathrm{~K}$ e os respectivos comprimentos de onda. Em detalhe a dependência da intensidade integrada da PL em função da temperatura. .68 
Figura 4.20: Espectro da fotoluminescência polarizada para o filme estirado de PPV obtido pela técnica S.A. à temperatura de $60 \mathrm{~K}$, para diferentes configurações da

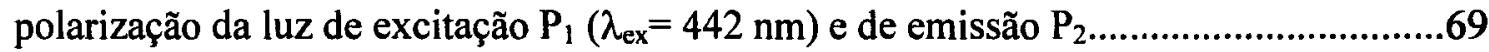

Figura 4.21: Medida da polarização da luz emitida pelo filme de PPV obtido pela técnica S. A. estirado 2 vezes do seu tamanho original. O Gráfico acima mostra a intensidade da luz emitida em função do ângulo do analisador $\mathrm{P}_{2}$ num intervalo $0^{\circ}$ a $360^{\circ}$, para as duas direções da polarização da luz de excitação, $P_{1}(/ /)$ paralelo e $P_{2}(\perp)$ perpendicular à direção de estiramento da amostra. 
Tabela 1: Os valores da integral $\mathbf{J}$ e os raios de Förster para os respectivos filmes de PPV. 


$\begin{array}{ll}\text { DBS } & \text { Ácido dodecilbenzenosulfonado. } \\ \text { eV } & \text { Elétron Volt. } \\ \text { Gap } & \text { Banda de Energia Proibida. } \\ \text { HOMO } & \text { Orbital Molecular Mais Alto Ocupado (Hight Occupied } \\ \text { Molecular Orbital). } & \\ \text { IFSC } & \text { Instituto de Física de São Carlos. } \\ \text { LB } & \text { Técnica Langmuir-Blodgett. } \\ \text { LED } & \text { Diodos Emissores de Luz (Ligh- emitting diodes). } \\ \text { LUMO } & \text { Orbital Molecular Mais Baixo Ocupado (Low Unoccupied } \\ \text { Molecular Orbital). } & \\ \text { PA } & \text { Poliacetileno. } \\ \text { PLEDs } & \text { Diodo Polimérico Emissor de Luz (PolymerLight-Emitting } \\ \text { Diodes). } & \\ \text { PPV } & \text { Poli(p-fenileno vinileno) } \\ \text { PL } & \text { Fotoluminescência } \\ \text { PTHT } & \text { Poli(cloreto de xilideno tethahidrotiofeno) } \\ \text { MeOH } & \text { Metanol } \\ \text { DBS } & \text { Sal de Sódio do Ácido dodecilbenzeno sulfonado } \\ \text { RET } & \text { Transferência Ressonante de Energia (Resonance Energy } \\ \text { Transfer). } & \\ \text { S.A } & \text { Técnica Self-Assembly } \\ \text { SC } & \text { Técnica Spin-Coating } \\ \text { UV-VIS } & \text { Ultravioleta-Visível } \\ \end{array}$




\begin{tabular}{|c|c|}
\hline$n$ & Grau de conjugação \\
\hline $\mathrm{E}_{\mathrm{g}}$ & Energia de Gap \\
\hline$R$ & Coordenadas normais de vibração \\
\hline $\mathrm{D}$ & Doador \\
\hline A & Receptor \\
\hline$k_{D}$ & Taxas de decaimento radiativo do doador. \\
\hline$k_{A}$ & Taxas de decaimento radiativo do aceitador \\
\hline$k_{T}$ & Taxa de transferência de energia de uma molécula para outra \\
\hline$k_{D i}$ & Desativações não-radiativas do doador. \\
\hline$k_{A i}$ & Desativações não-radiativas do aceitador. \\
\hline$E$ & Eficiência de transferência. \\
\hline$R_{0}$ & Distância crítica de transferência ou Raio de Förster. \\
\hline W & Energia do dipolo \\
\hline$m$ & Massa do elétron \\
\hline$k$ & Fator de orientação. \\
\hline$e$ & Carga do elétron \\
\hline$E_{0}$ & Amplitude do campo elétrico \\
\hline$\vec{\mu}_{a b}$ & Momento de dipolo elétrico \\
\hline$I_{0}$ & Intensidade da Luz Incidente \\
\hline$T$ & Transmitância \\
\hline$A$ & Absorbância \\
\hline$P_{1}$ & Polarizador \\
\hline $\mathbf{P}_{2}$ & Polarizador Analisador \\
\hline $\mathrm{A}_{\perp}$ & Absorção da luz com direção de polarização perpendicular \\
\hline $\mathrm{A}_{/ /}$ & Absorção da luz com direção de polarização paralela \\
\hline$\delta$ & Razão Anisotropica \\
\hline$\beta$ & Parâmetro de ordem molecular no plano do filme \\
\hline
\end{tabular}


$\lambda_{\text {ex }}$

$r$

Comprimento de Onda de Excitação

Anisotropia de Emissão 


\section{RESUMO}

Polímeros conjugados têm sido tema de várias pesquisas devido à sua potencialidade de aplicação em dispositivos optoeletrônicos. Esses materiais apresentam propriedades luminescentes que envolvem processos fotofísicos ainda pouco compreendidos devido à grande variedade morfológica assumida por suas cadeias poliméricas. Neste trabalho, apresentamos os resultados que evidenciam a influência da morfologia molecular (ordenamento e empacotamento) no estado final da polarização da luz emitida (luminescência) pelos filmes de poli(p-fenileno vinileno) (PPV). Foram preparados filmes de PPV com diferentes ordenamentos moleculares, obtidos a partir dos seguintes métodos e técnicas de montagem de filmes: Casting, Spin-Coating (SC), Langmuir-Blodgett (LB) e Self-Assembly (S.A). As propriedades ópticas dos filmes foram investigadas através das medidas de absorção (UV-VIS) polarizada, de fotoluminescência (PL) em diferentes temperaturas $(10 \mathrm{~K}$ a $300 \mathrm{~K})$ e da análise da polarização da luz emitida. As medidas ópticas de absorção e de emissão de luz polarizada revelaram que os filmes obtidos por Langmuir-Blodgett, Casting e SelfAssembly com estiramento mostraram-se anisotrópicos, emitindo luz com polarização na direção do estiramento ou de imersão (quando preparados por LB), independente da direção de polarização da luz de excitação. Os filmes obtidos por Casting e SpinCoating, por outro lado, mostraram-se isotrópicos, emitindo luz com polarização na direção da polarização da luz de excitação. Os resultados obtidos da medida da polarização da luz emitida evidenciaram a ocorrência de transferência de energia entre moléculas. Deste modo, utilizou-se a teoria de Förster (radiação dipolo-dipolo) para explicar os resultados obtidos para os diferentes filmes de PPV, permitindo correlacionála com as propriedades ópticas e com o ordenamento molecular dos filmes. 


\section{ABSTRACT}

Since the first report of polymer light-emitting diodes (PLEDs), there have been considerable efforts to understand the emission process in luminescent polymers. However, many aspects related to this process are still under investigation, as the influence of morphology assumed by the polymeric chains. In this work we studied the influence of the molecular morphology, as ordering and packing, on the polarized lightemitting of poly( $p$-phenylenevinylene) - PPV films. It was obtainef films with different molecular arrangements from different assembly techniques, as Casting, Spin-Coating (SC), Langmuir-Blodgett (LB), and Self-Assembly (S.A). The optical property was investigated by absorption spectroscopy (UV-VIS), photoluminescence spectra (PL), and polarized light-emitting. The optical measurements disclosed that LB-PPV films, Casting-PPV and S.A-PPV stretched films were optically anisotropic, where the direction of the light-emitting is the same of the stretched direction or dipping preparation. In the other hand, Casting-PPV and Spin-Coating did not have such behavior, i.e., the emitted polarized light propagated in the same direction of the polarization of the excitation light. These data acquired from the optical measurements indicate a relation between morphology and photophysical process involving energy transfer via Förster. 


\section{Capítulo 1}

INTRODUÇÃO 
Desde a descoberta dos materiais poliméricos, nas primeiras décadas do século $\mathrm{XX}$, suas aplicações na área elétrica/eletrônica ficaram restritas a isoladores devido à sua alta resistividade elétrica. No final da década de 70, a partir dos trabalhos de Shirakawa, MacDiarmid e Heeger observou-se pela primeira vez que a condutividade de um polimero pode ser variada sob dopagem química, atingindo valores semelhantes à dos metais [1]. O poliacetileno, por exemplo, quando dopado com iodo apresentava condutividade elétrica bilhões de vez maior que a obtida com o material não dopado [2]. No início da década de 80 , vários outros polímeros condutores foram sintetizados e estudados, mas foi ainda com o poliacetileno semicondutor que ocorreu a primeira aplicação em diodos e transistores. Surgiram, assim, novas perspectivas para o uso destes materiais como elementos ativos em dispositivos eletrônicos [3]. No entanto, devido à dificuldade em se obter filmes finos e homogêneos, à baixa mobilidade dos portadores eletrônicos e à instabilidade dos dispositivos, aplicações comerciais desses novos materiais não foram concretizadas. Com o avanço nas técnicas de preparação de filmes finos, as dificuldades foram superadas e em 1987, dois pesquisadores da Eastman Kodak anunciaram propriedades eletroluminescentes de materiais orgânicos (nãopoliméricos) [4], e três anos mais tarde, o grupo do Prof. R. H. Friend concluiu a fabricação de um diodo emissor de luz (polymer light-emitting diodes - PLEDs) usando o poli(p-fenileno vinileno) (PPV) como camada emissiva [5-6], consolidando uma nova classe de materiais ativos na eletrônica e optoeletrônica. Nas últimas décadas a classe de materiais denominados semicondutores orgânicos emissores de luz [7-10] incluindo os polímeros conjugados e as macromoléculas, tem sido bastante pesquisada por apresentar propriedades ópticas e elétricas semelhantes aos tradicionais semicondutores inorgânicos. Esses novos materiais apresentam grande vantagem em relação aos tradicionais, a sua processabilidade é de baixo custo, podem ser produzidos na forma de filmes finos e os PLEDs apresentam altas eficiências, baixa tensão de operação e com emissão em vários comprimentos de onda do espectro visível (quando sujeitos a pequenas modificações em sua estrutura química). Todas essas propriedades do PPV e seus derivados fazem os tornarem materiais de grande interesse científico e tecnológico 
[5,9-10]. Embora o atual estágio de desenvolvimento tecnológico dos dispositivos eletrônico polimérico esteja bastante avançado, o controle e a otimização das suas propriedades ópticas e elétricas, assim como os fenômenos responsáveis pela eficiência de luminescência, pela degradação e pelos processos de interações intermoleculares, ainda são pouco compreendidos. $\mathrm{O}$ controle e a melhoria das propriedades óptica e elétrica dos dispositivos poliméricos emissores de luz estão relacionados com o grau de orientação de suas cadeias poliméricas e os mecanismos de transportes de energia entre as moléculas que absorvem e que emitem luz [11-13]. Devido à habilidade exclusiva dos polímeros em se tornarem materiais anisotrópicos por um simples estiramento ao longo de uma direção, PLEDs construídos a partir de uma superfície polimérica estirada apresentam emissão de luz polarizada com razão de intensidade de 3,1 entre a luz emitida paralelamente e a luz emitida perpendicular à direção do estiramento [14]. Em vista da operação dos dispositivos eletrônicos poliméricos ser fortemente influenciada pela anisotropia das propriedades ópticas e elétricas, a correlação entre a polarização da luz emitida e a morfologia de filmes poliméricos luminescentes se torna um estudo de grande interesse [14-17].

Dentro deste contexto, o objetivo deste trabalho foi estudar a influência do ordenamento molecular no estado de polarização da luz emitida pelos filmes de poli ( $p$ fenileno vinileno) (PPV). Filmes orientados foram obtidos por diferentes processos preparação, e em seguida foram estudados os mecanismos de transporte de energia entre seus segmentos conjugados. No capítulo 2 , são apresentados os conceitos básicos sobre a estrutura eletrônica dos polímeros conjugados e em particular do PPV, assim como os mecanismos de transporte de energia entre moléculas. $O$ material utilizado, as técnicas empregadas na obtenção dos filmes e os métodos empregados na investigação das propriedades fotofísicas dos filmes, bem como as medidas de espectroscopia de absorção e emissão (PL) polarizadas, estão descritas no capítulo 3. Os resultados de absorção e emissão dos filmes de PPV, assim como as evidências da influência da morfologia (ordenamento e empacotamento) molecular no processo de transferência de energia estão apresentadas no capítulo 4. No capítulo 5 são apresentadas as conclusões e considerações finais. 


\section{Capítulo 2}

PROCESSOS FOTOFÍSICOS EM POLÍMEROS CONJUGADOS 


\subsection{POLÍMEROS CONJUGADOS}

Os polímeros são moléculas longas cujo nome deriva do termo grego, poli (muita) e mero (partes) e sua estrutura é resultado do processo químico de polimerização de unidades estruturais (grupos funcionais) menores e idênticas chamadas monômeros. Os polímeros orgânicos são compostos por elementos como carbono e hidrogênio, eventualmente ligados a estes aparecem o oxigênio, nitrogênio e halogênios. Uma classe de moléculas orgânicas de especial interesse e com grande potencial de aplicação em dispositivos eletroluminescentes é a dos polímeros conjugados, geralmente formando uma cadeia principal de átomos de carbono ligados lateralmente por átomos de hidrogênio.

Os polímeros conjugados são compostos orgânicos que apresentam elétrons $\pi$ não localizados, como o butadieno $\left(\mathrm{C}_{4} \mathrm{H}_{6}\right)$, poliacetileno $(-\mathrm{C}=\mathrm{C}-)_{\mathrm{n}}$ e o poli ( $p$-fenileno vinileno) ou PPV $\left(-\mathrm{C}_{6} \mathrm{H}_{4}-\mathrm{C}=\mathrm{C}-\right)_{\mathrm{n}}$. A estrutura eletrônica de moléculas conjugadas é determinada basicamente pelas ligações entre carbonos chamadas de ligações $\sigma$, formadas pela superposição de orbitais híbridos $s p^{2}$ ao longo do plano da molécula como mostra a Figura 2.1a, onde ilustra também a distribuição de probabilidade eletrônica do butadieno. Mas em adição, existem as ligações $\pi$ formadas pela superposição lateral dos orbitais atômicos $p_{z}$ entre carbonos adjacentes [18]. Por esse motivo, os elétrons dos orbitais moleculares $\pi$ se comportam de modo especial. Esses elétrons são deslocalizados e podem se mover ao longo do segmento conjugado da molécula ao invés de estarem confinados a uma região particular da molécula, como estão os elétrons da ligação $\sigma$. A Figura $2.1 \mathrm{~b}$ ilustra a distribuição eletrônica da ligação $\pi$ que se encontra perpendicularmente ao plano dos átomos de carbono consecutivos e apresenta seus elétrons não localizados ao longo do segmento conjugado. As propriedades ópticas e elétricas de polímeros surgem da natureza conjugada destas macromoléculas $[3,10]$. 


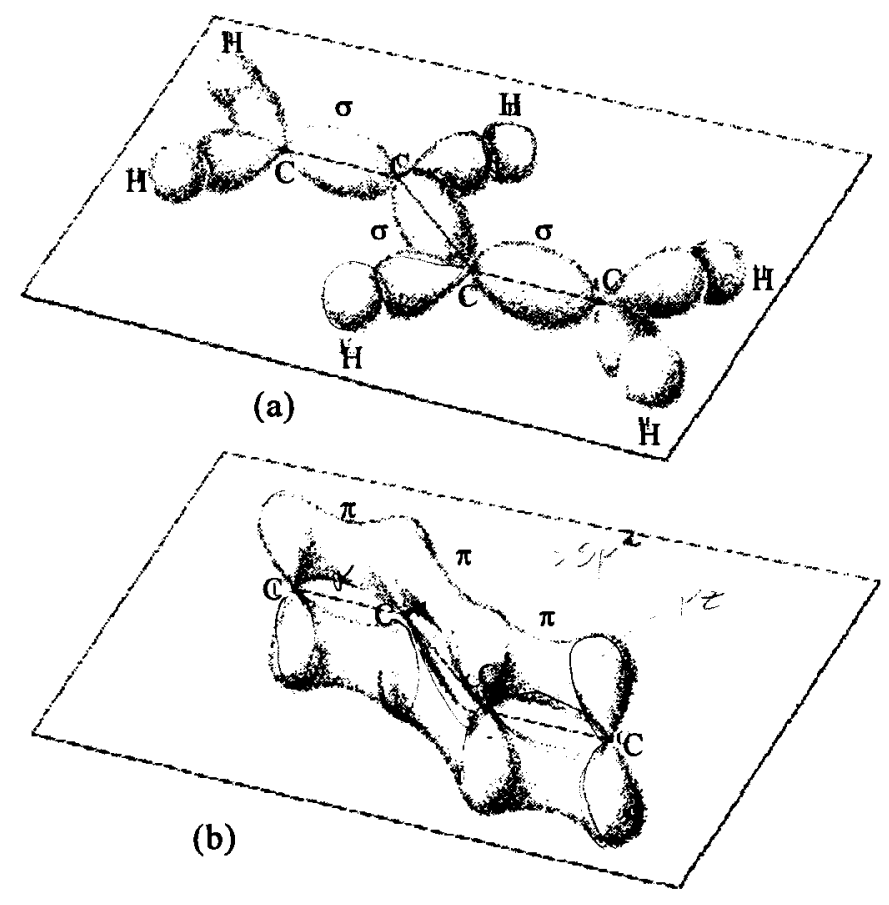

Figura 2.1: Distribuição de probabilidade eletrônica do Butadieno $\left(C_{4} H_{6}\right)$. (a) Orbitais $\sigma$ localizados, paralelos ao plano da molécula; (b) Orbitais $\pi$ não localizados, perpendiculares ao plano da molécula[18].

Deste modo, a não localização dos estados gerada pela superposição dos orbitais pz pode ser descrita através da teoria de bandas aplicada a uma cadeia unidimensional e periódica e infinita. Como os orbitais moleculares entre carbonos adjacentes possuem somente um elétron por sítio, a banda de valência ou a banda $\pi$ (estados ligantes) de menor energia é totalmente preenchida. A banda de valência está separada dos estados superiores desocupados, denominadas bandas de condução ou bandas $\pi^{*}$ (estados antiligantes) por uma lacuna de energia proibida (Gap) da ordem de 2,0 eV, o que confere um caráter semicondutor aos polímeros conjugados, como ilustrado na Figura 2.2a pelo diagrama de energia. A estrutura de banda do PPV em particular, é ilustrada pela Figura 2.2b [19]. 
(a)

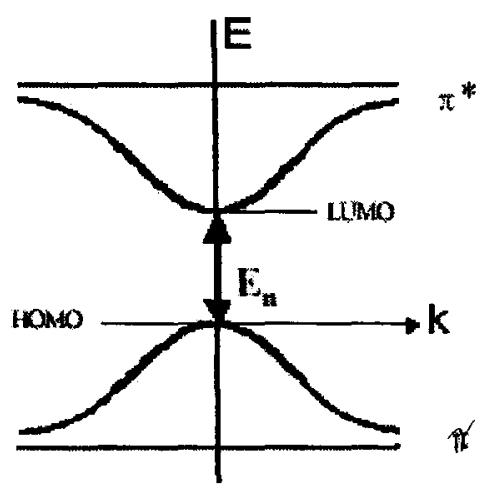

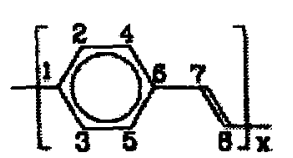

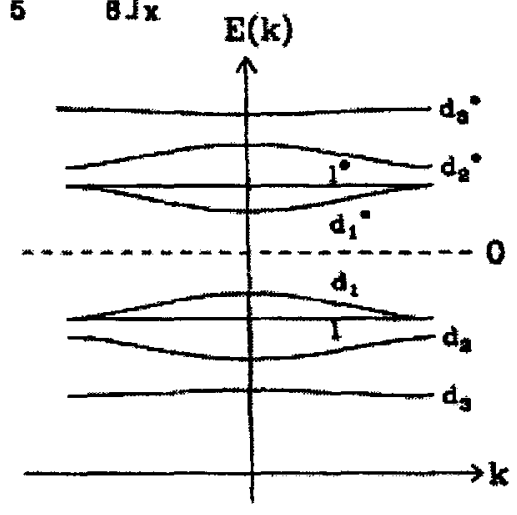

(b)

Figura 2.2: (a) Ilustração esquemática do diagrama de energia na representação de coordenadas. (b) Estrutura eletrônica do PPV [19], as letras d e d*indicam estados localizados e não localizados, respectivamente.

\subsubsection{ESTRUTURA ELETRÔNICA DOS POLÍMEROS CONJUGADOS}

As ligações $\sigma e \pi$ nos polímeros conjugados são responsáveis pela alternância de ligações simples (longas) e duplas (curtas) ao longo da molécula, denominada conjugação ou dimerização [20-21]. O número de unidades monoméricas com ligações simples e duplas sem interrupção é definido como grau de conjugação (n), e tem uma enorme influência na configuração eletrônica das moléculas conjugadas. No processo de conversão do PTHT em PPV o produto final é uma cadeia semi-conjugada, ou melhor, uma distribuição aleatória de segmentos conjugados e não-conjugados. Portanto, há uma distribuição de segmentos com diferentes graus de conjugação, de modo que os estados eletrônicos $\pi e \pi^{*}$ são mais ou menos localizados. Em analogia ao modelo de elétron numa caixa de potencial, o tamanho da conjugação $(L)$ equivale à largura da caixa $(L=$ $n_{c} a$ ) onde $a$ é o comprimento da unidade monomérica. Uma conjugação média efetiva pequena $\left(n_{c}<10\right)$, implica no aumento da energia do Gap entre os estados ligantes e 
antiligantes. Para grandes valores de $n_{c}(>15)$ a energia do $\operatorname{Gap}\left(E_{n}\right)$ é igual a $2,5 \mathrm{eV}$, que é justamente o valor do Gap do PPV como mostra o gráfico da Figura 2.3 [22].

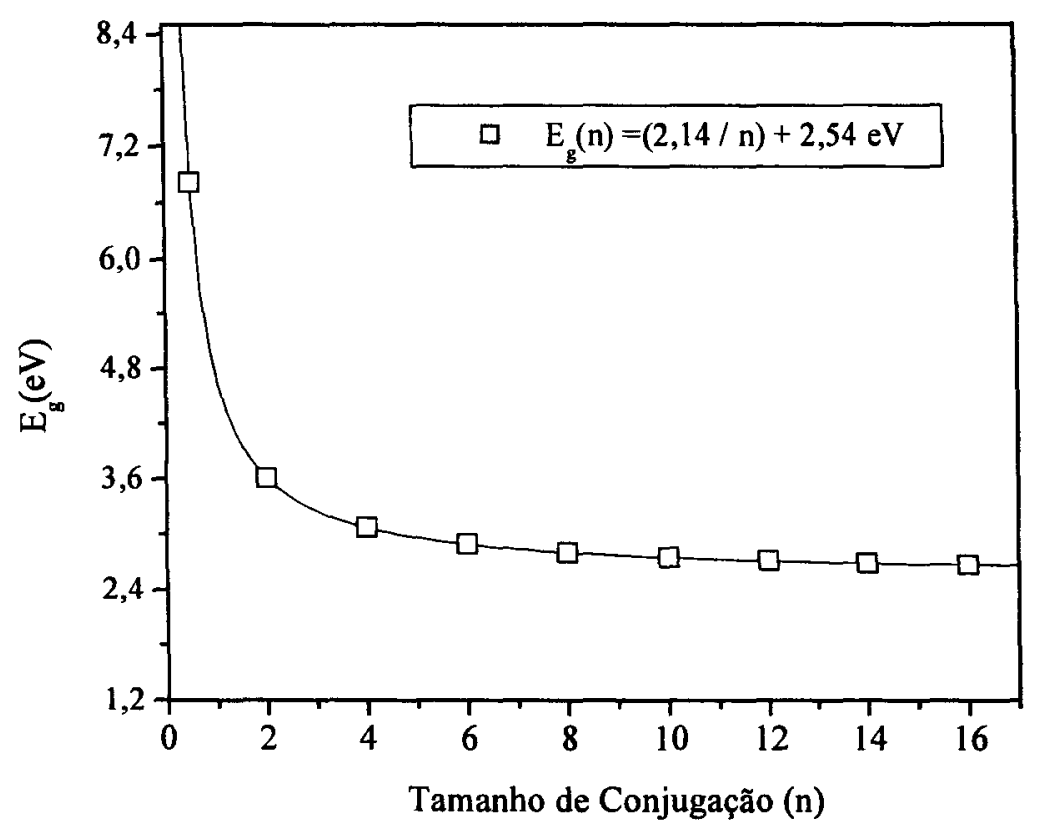

Figura 2.3: Variação da energia de Gap $\left(E_{g}\right)$ em função do tamanho de conjugação $(0 \leq L \geq 16)$ para o oligômero de PPV.

Portanto, o modelo físico considerado neste trabalho foi baseado na presença destes estados eletrônicos localizados em algumas unidades repetitivas, dadas por uma distribuição dos diferentes tamanhos de segmentos conjugados ao longo da cadeia principal causada pelas mudanças conformacionais (cis para trans), pelos defeitos como torções (inversões abruptas ou desordem conformacional), enovelamento e degradação estrutural (reações de fotodegradação) (Figura 2.4a). Como a variação do grau de conjugação $\left(n_{c}\right)$ dos segmentos conjugados afeta diretamente a energia do Gap, o resultado final do modelo físico é um sistema unidimensional com modulação da energia ao longo da cadeia polimérica principal, como ilustrado na Figura 2.4b. Esta estrutura energética associada é equivalente a descrição de poços quânticos unidimensionais, as linhas pontilhadas representam os estados localizados para as bandas de energia $\pi e \pi^{*}$. 

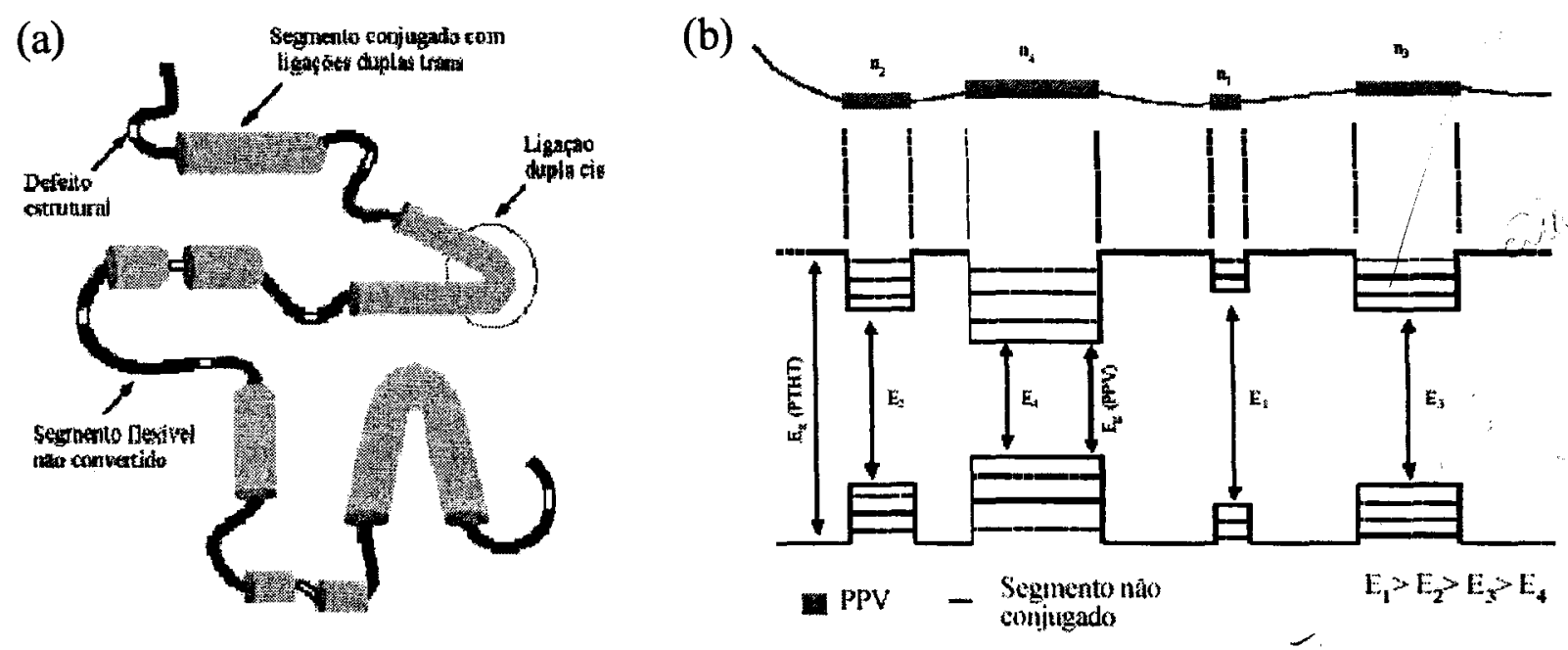

Figura 2.4: (a) Representação conformacional da quebra de conjugação de um copolímero causada por defeitos estruturais e conformacionais. (b) Ilustração do modelo fisico envolvendo de segmentos conjugados de diferentes tamanhos, separados por segmentos não conjugados.

\subsubsection{ABSORÇÃO E EMISSÃO EM POLÍMEROS CONJUGADOS}

Pelo fato do domínio de comprimentos de conjugação das cadeias poliméricas ser bastante extenso no PPV, o formalismo teórico baseado em cálculos de química quântica semi-empíricos (ou teoria de orbital molecular) descreve razoavelmente bem a estrutura eletrônica do PPV. Além disso, a promoção de um elétron de um estado $\pi$ para um outro $\pi^{*}$ resulta na mudança da conformação molecular de equilíbrio, o que é visto experimentalmente pelo forte acoplamento entre os estados eletrônicos e vibracionais nas transições ópticas. Assim, o modelo físico em questão deve incluir o fato de cada estado eletrônico estar acoplado a um conjunto de estados vibracionais. A Figura 2.5 ilustrada o acoplamento nos níveis de energia eletrônico com os modos vibracionais em macromoléculas. Considere os estados HOMO e LUMO da estrutura de banda, denominados respectivamente de $a$ e $b$ no diagrama de energia. Na representação de coordenadas normais de vibração $(\mathrm{R})$, o diagrama de energia devido ao acoplamento dos 
níveis de energia a e b e vibracional é agora representado pela soma da energia potencial vibracional ao nível de energia eletrônico.
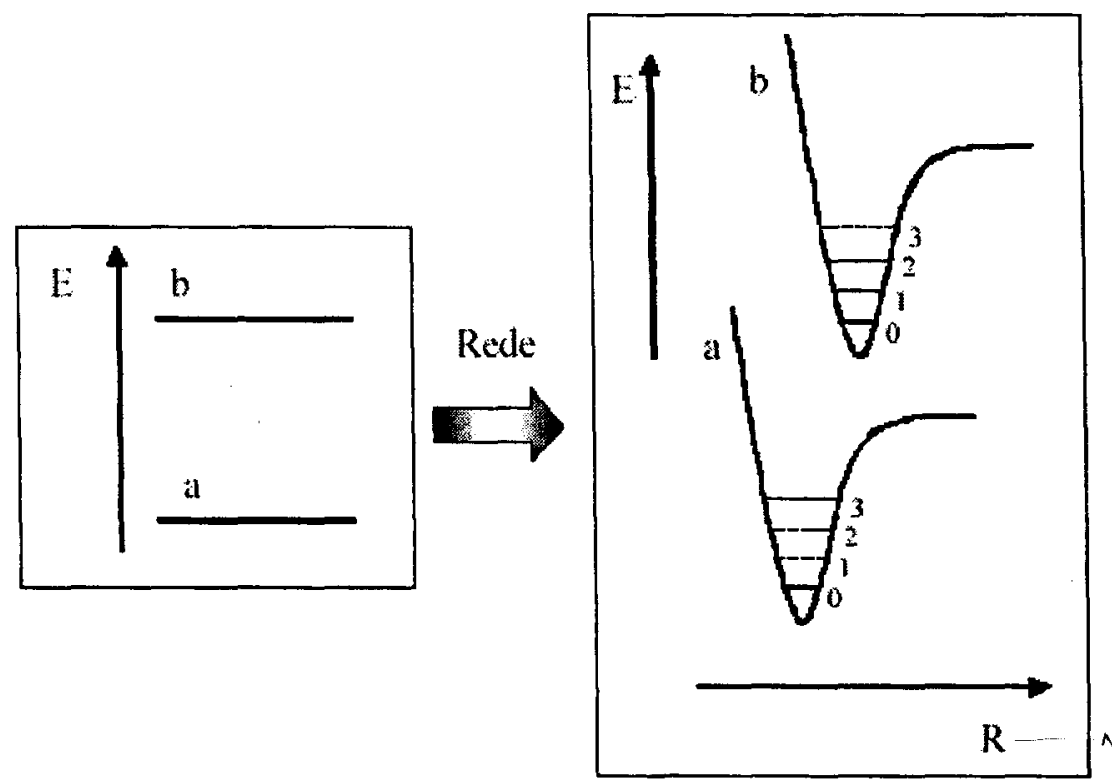

Figura 2.5: Esquema energético do acoplamento elétron-fônon. Inicialmente tem-se o estado eletrônico a (HOMO) e b (LUMO) que são somados a energia potencial vibracional $e$ representados nas coordenadas normais de vibração da macromolécula.

Uma vez que os estados eletrônicos são acoplados com o espectro vibracional da cadeia polimérica, os espectros de absorção e emissão nos semicondutores orgânicos podem ser esquematizados de acordo com a Figura 2.6 através de um diagrama de energia. Nesta figura, as energias do estado fundamental $a$ e excitado $b$ são mostradas na representação das coordenadas normais $(R)$ do sistema, assim como os potenciais e as energias dos modos vibracionais (estado fundamental $a: 0,1, \ldots$ e estado excitado $b: 0,1$, ...) que, em geral, são deslocados espacialmente devido a diferenças conformacionais. Os processos de relaxação dentro da banda de energia, após a excitação, definem a separação entre os espectros de absorção e emissão (deslocamento Stokes). As transições ópticas entre dois estados moleculares (absorção $a \rightarrow b$ e emissão $b \rightarrow a$ ) estão representadas na Figura 2.6 pelas linhas verticais, conhecidas como transições de Franck-Codon [18]. É importante notar que esta é uma representação simples dos 
processos ópticos de interesse neste trabalho, tal como discutido acima, é preciso considerar vários outros fatores como distribuição de segmentos conjugados e processos de relaxação energética não radiativos.

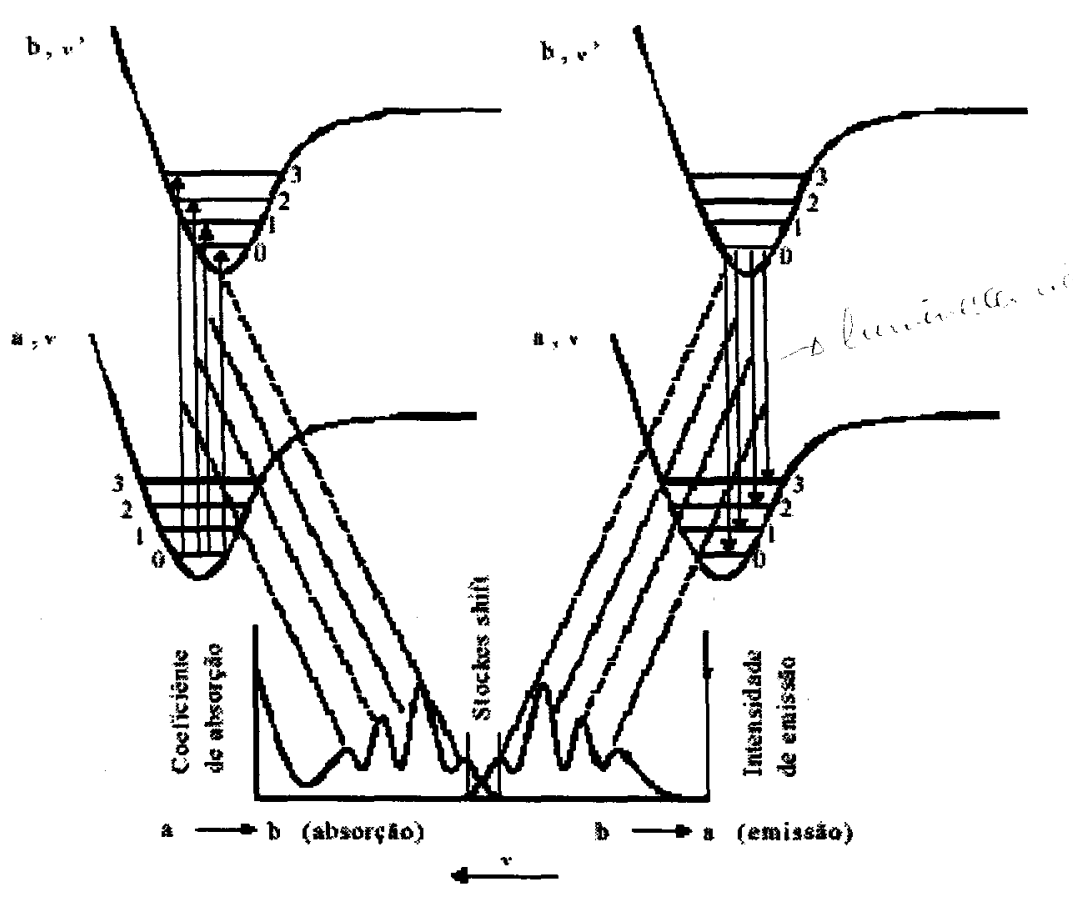

Figura 2.6: Processo de absorção e emissão entre estados moleculares com acoplamento elétron-fônon.

Dentro do modelo físico tratado acima, o espectro de absorção é composto pela superposição de transições eletrônicas $\left(\pi \rightarrow \pi^{*}\right)$ com um peso que depende da distribuição de tamanhos de segmentos conjugados $n$, formado assim uma região espectral larga de energia entre 4,2 a $2,3 \mathrm{eV}$ (região UV-Vis do espectro eletromagnético). Este modelo de distribuição de segmentos conjugados ao longo da cadeia polimérica principal é concordante com os cálculos efetuados por J. Orbzut e colaboradores [23] e J. Yu e colaboradores [18, 24-27]. As transições radiativas (luminescência) ocorrem entre a banda $\pi^{*}$ para a banda $\pi\left(\pi^{*} \rightarrow \pi\right)$ de acordo com Figura 2.6, após a relaxação energética nos portadores de carga excitados para o fundo da banda 
$\pi^{*}$ (estado LUMO). Durante a relaxação energética podem ocorrer processos competitivos relacionados à difusão de carga entre segmentos conjugados e/ou transferência de energia (mecanismo de Förster) para regiões de menor energia, ou seja, para segmentos com maiores graus de conjugação. Alguns desses processos estão descritos com mais detalhes no item seguinte (item 2.4).

\subsection{PROCESSOS INTERMOLECULARES}

Até o presente momento foram descritos e discutidos os processos fotofísicos intramoleculares, ocorridos em uma molécula isolada. Em sistemas poliméricos os processos intermoleculares também ocorrem com bastante freqüência e seus efeitos são de grande interesse para estudo dos processos e mecanismos de transporte de energia entre moléculas excitadas.

\subsubsection{MECANISMOS DE TRANSPORTES EM MACROMOLÉCULAS}

Dependendo da natureza das interações entre doador e receptor, diferentes mecanismos têm sido sugeridos para explicar fenômenos de migração de energia [28]. A transferência ou migração de energia é a transmissão da radiação de um quantum de energia de um sítio de absorção para um sítio de utilização na molécula ou sistemas de moléculas em distâncias consideráveis, maiores que as interatômicas, sem haver conversão em energia térmica e sem colisão cinética entre o doador (inicialmente absorve energia) e o receptor (para o qual energia é subseqüentemente transferida) [2930]. 


\subsubsection{TRANSFERÊNCIA DE ENERGIA RESSONANTE (RET)}

A transferência de energia ressonante ou "Resonance Energy Trasnfer" (RET), em polímeros conjugados é um processo característico nas interações intermoleculares. A migração de energia é definida como a doação da energia de uma molécula doadora excitada para outra molécula receptora no estado fundamental, podendo ser representadas de uma forma geral pela equação:

$$
D+A+h v \rightarrow \mathrm{D}^{*}+\mathrm{A} \stackrel{k_{T}}{\rightarrow} \mathrm{D}+\mathrm{A}^{*}
$$

Onde $D^{*}$ representa uma molécula doadora inicialmente excitada, $A$ representa uma molécula receptora e $k_{T}$ é a taxa de transferência. Para observar claramente o RET, é necessário satisfazer algumas condições [28]:

1. O cromóforo doador e o receptor devem apresentar fortes transições eletrônicas nas extensões espectrais próximas ao ultravioleta e ao infravermelho, respectivamente;

2. Deve haver uma sobreposição considerável do espectro de emissão do doador excitado com o espectro de absorção do receptor;

3. O doador e o receptor devem estar relativamente próximos um do outro, mas não muito próximos, entre $10-100 \AA$;

Um sistema contendo doador e receptor, excitado por uma luz com comprimento de onda no qual as moléculas doadoras absorvem e transferem energia para as moléculas receptoras, pode ser esquematizado pela Figura 2.7. 


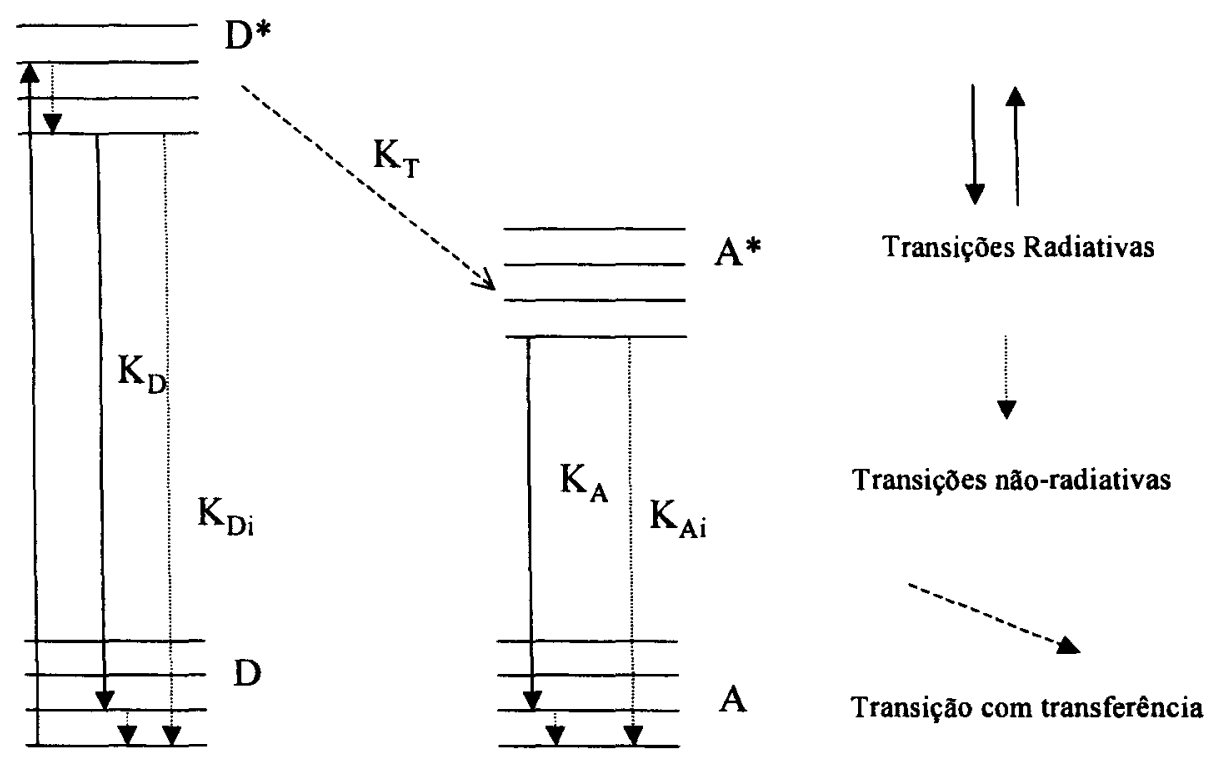

Figura 2.7: Diagrama de niveis de energia simplificado da transferência de energia ressonante. $D$ refere-se ao doador e $A$ ao receptor, os asterísticos denotam estado excitados.

Esse sistema pode ser descrito por uma equação mais geral que leva em consideração os decaimentos radiativos e não-radiativos como:

$$
\begin{array}{ccc}
D+A & D+A \\
\uparrow k_{D i} & \uparrow k_{A i} \\
D+A+h v_{E} \rightarrow D^{*}+A \stackrel{k_{T}}{\rightarrow} & D+A^{*} \\
\downarrow k_{D} & \downarrow k_{A} \\
A+D+h v_{D} & A+D+h v_{A}
\end{array}
$$

onde $k_{D}$ e $k_{A}$ são as taxas de decaimento radiativo do doador e do receptor, respectivamente. A taxa de transferência de energia é descrita por $k_{T}$, onde $h$ é a constante de Planck e $v_{E}, v_{D} e v_{A}$ são as freqüências de excitação do doador, da 
luminescência do doador e luminescência do receptor, respectivamente e as constantes $k_{D i}, k_{A i}$ são referentes as desativações não-radiativas do doador e do receptor.

A fração de fótons absorvidos que são transferidos, sem radiação, para o receptor é denominada de eficiência de transferência (E), escrita como:

$$
E=\frac{k_{T}}{k_{T}+k_{D}+k_{D i}}
$$

A eficiência também pode ser obtida a partir do tempo de vida do doador na presença e na ausência da transferência, através da equação da taxa de decaimento radiativo entre doador e receptor a uma distância $(R)$ um do outro, dada por [28]:

$$
K_{T}=\left(k_{D}+k_{D i}\right)\left(\frac{R_{0}}{R}\right)^{6}=\frac{1}{\tau_{D}}\left(\frac{R_{0}}{R}\right)^{6}
$$

Onde $\tau_{D}=1 /\left(k_{D}+k_{D i}\right)$ é o tempo de vida do estado do doador na ausência do doador e $R_{0}$ é a distância crítica de transferência ou raio de Förster (discutido a seguir), ou seja, é a distância ao qual a taxa (ou probabilidade) de transferência equivale a somatória de todas as outras taxas (probabilidade) de desativação do estado excitado do doador $\left(k_{T}=\right.$ $k_{D}+k_{D i}$ ). Substituindo a equação (2.4) na equação (2.3), obtêm-se, portanto:

$$
E=\frac{R_{0}^{6}}{R_{0}^{6}+R^{6}}
$$

$\mathrm{Na}$ Eq. 2.5, $\mathrm{R}_{0}$ também pode ser definido como a distância doador - receptor, quando a eficiência de transferência é de $50 \%$. A eficiência cai se $R$ aumenta e sobe se $R_{0}$ aumenta. De acordo com a Figura 2.8 essas mudanças são rápidas para $R \approx R_{0}$ e são lentas se a distância doador-receptor é muito maior ou muito menor que a distância 
Förster. Deve-se enfatizar que as equações (2.4) e (2.5) somente são asseguradas se a distância doador-receptor estiver entre 10 e $100 \AA \AA$.
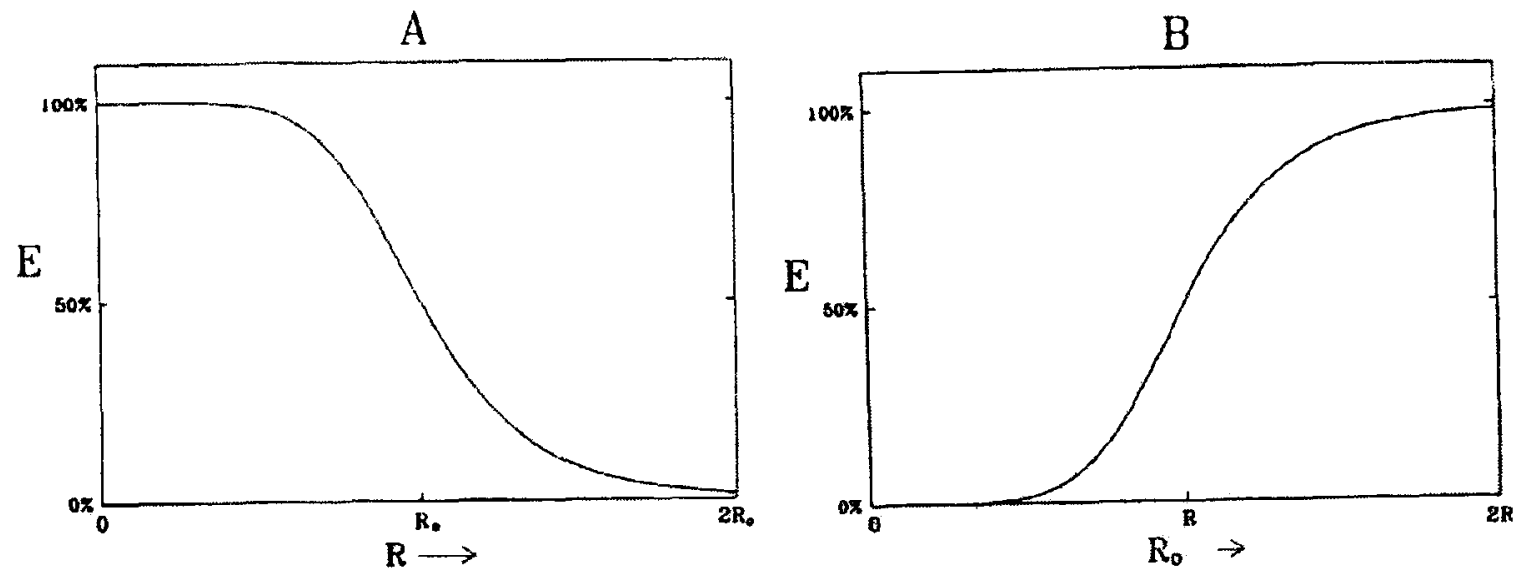

Figura 2.8: A eficiência da transferência, $E$, em função da distância doador-receptor, $R(A), e$ em função da distância crítica de transferência, $R_{0}(B)$, de acordo com a equação (2.5).

\subsection{3: TRANSFERÊNCIA DE ENERGIA (TEORIA DE FÖRSTER)}

A primeira idéia para descrever a transferência de energia foi proposta por $\mathrm{J}$. Perrin em 1920 e mais tarde interpretada em termos da mecânica quântica por F. Perrin [31]. O modelo teórico de F. Perrin mostrou que a energia de excitação eletrônica poderia ser transferida através de distâncias acima de centenas a alguns milhares de ângstrons. Em 1940, Th. Förster [13] baseado na aproximação da mecânica quântica e na consideração de que as moléculas seriam um conjunto de dipolos oscilando num intervalo de freqüência, concluiu que a transferência de energia poderia ocorrer em distâncias de aproximadamente de $100 \AA$ entre moléculas de mesmo momento de dipolo, independente da temperatura [32]. Se um dipolo elétrico orientado a longo da direção $x$ tem exatamente a mesma freqüência de um campo elétrico externo, o qual 
oscila cosenoidalmente ao longo da mesma direção, então a energia absorvida por esse dipolo depois de um tempo $t$ é:

$$
W=\frac{e^{2} E_{0 x}^{2}}{8 m} t^{2}
$$

onde $e$ é a carga do elétron, $m$ a massa do oscilador e $E_{0 x}$ é a amplitude do campo elétrico. A amplitude da componente do campo elétrico ao longo de um dipolo receptor (alinhado com a direção $x$ ) produzido pelas oscilações do doador é dada por:

$$
E_{0 x}=\frac{k \cdot e \cdot a}{n^{2} R^{3}}
$$

onde $K$ é um fator orientação, $a$ é a amplitude do oscilador, $n$ o índice de refração do meio no qual o doador e o receptor estão inseridos e $R$ é a distância entre eles. Esta distância é assumida como sendo muito maior que o raio efetivo da distribuição de carga do doador. Substituindo a equação (2.7) na (2.6), obtém-se a energia absorvida pelo receptor, $W_{a}$ após um tempo $t$ sendo perfeita a ressonância entre freqüência do doador e do receptor, é dada por:

$$
W_{a}=\frac{k^{2} e^{4} a^{2}}{8 n^{4} m R^{6}} t^{2}
$$

A energia do dipolo doador $W_{D}$ para uma amplitude $a$, massa $m$, com constante da mola $k$ e freqüência $v=\omega / 2 \pi=\sqrt{k / m /(2 \pi)}$ é descrita por:

$$
W_{D}=\frac{k}{2} a^{2}=\frac{m}{2} \omega^{2} a^{2}
$$


Substituindo $a^{2}=2 W_{D} /\left(m \omega^{2}\right)$ na equação (2.8), obtém-se a relação entre $W_{a} \mathrm{e}$ $W_{D}$ :

$$
W_{a}=\frac{k^{2} e^{4} W_{D}}{4 n^{4} m^{2} \omega^{2} R^{6}} t^{2}
$$

A equação (2.10) somente é válida considerando a perfeita ressonância entre os dipolos doadores e receptores. Contudo, o doador e o receptor consistem de um conjunto de osciladores com uma certa diferença entre as frequiências. Desse modo, se introduz um oscilador força $f_{e D}(\omega)$ e $f_{a A}(\omega)$ para a emissão dos dipolos doadores e a absorção dos dipolos receptores, respectivamente [28]. A fração do dipolo receptor $f_{a A}(\omega) d \omega$, com freqüência angular entre $\omega \mathrm{e} \omega+d \omega$, pode somente transferir energia daqueles dipolos doadores que têm frequiência limitada neste intervalo $\omega$. Isto é, a fração do dipolo receptor, $f_{a A}(\omega) d \omega$ está em ressonância com a fração do dipolo doador $f_{e D}(\omega) \Delta$, onde $\Delta=2 \pi / t$ é a largura da freqüência angular onde ocorre a ressonância. Multiplicando o lado direito da Eq. (2.10) pelas frações $f_{a A}(\omega) d \omega, f_{e D}(\omega)(2 \pi / t)$ e integrando em $\omega$, a energia total adquirida pelo receptor que resulta da ressonância da interação dipolo-dipolo com o doador é expressa como:

$$
W_{a}=\frac{\pi k^{2} e^{4}}{2 n^{4} m^{2} \omega^{2} R^{6}} \cdot W_{D} \cdot t \int_{0}^{\infty} f_{e D}(\omega) \cdot f_{a A}(\omega) \frac{d \omega}{\omega^{2}}
$$

A potência transferida é a derivada de $W_{D}$ em função do tempo, dada por:

$$
P=\frac{d W_{D}}{d t}=\frac{\pi k^{2} e^{4}}{2 n^{4} m^{2} \omega^{2} R^{6}} \cdot W_{D} \int_{0}^{\infty} f_{e D}(\omega) \cdot f_{a A}(\omega) \frac{d \omega}{\omega^{2}}
$$


Esta potência também pode ser escrita em termos da taxa de transferência $k_{T}$, que corresponde a um número médio de transferência por unidade de tempo para um emissor constantemente re-excitado.

$$
\frac{d W_{D}}{d t}=k_{T} \cdot W_{D}
$$

Combinando as Eq. (2.12) e (2.13) e mudando a freqüência angular $\omega$ para freqüência linear $v=\omega / 2 \pi$, têm-se:

$$
k_{T}=\frac{K^{2} e^{4}}{16 \pi^{2} n^{4} m^{2} \omega^{2} R^{6}} \int_{0}^{\infty} f_{e D}(v) f_{a A}(v) \frac{d v}{v^{2}}
$$

onde $f(\omega)=f(v) / 2 \pi$. Os osciladores força $f_{e D}(\omega)$ e $f_{a A}(\omega)$ são obtidos das propriedades espectrais, $f_{a A}(\omega)$ é proporcional a $\varepsilon_{\mathrm{A}}(v)$, que é conhecido como coeficiente de extensão molar do receptor, e $f_{e D}(\omega)$ é proporcional a $f_{D}(v)$, que é o espectro de luminescência do doador:

$$
\begin{aligned}
& f_{a A}(v)=\frac{3000 n(\ln 10) m c}{\pi N_{A V} e^{2}} \cdot \varepsilon_{A}(v) ; \\
& f_{e D}(v)=\frac{3 m c^{2} \eta_{D}}{8 \pi^{2} n e^{2} \tau_{D}} \frac{f_{D}(v)}{v^{2}} ;
\end{aligned}
$$

onde $c$ é a velocidade da luz no vácuo, $N_{A V}$ é o número de Avogadro e $\tau_{D}$ e $\eta_{D}$ são, respectivamente, o tempo de vida e o campo quântico do doador na ausência do receptor. Neste caso, $f_{D}(v)$ é normalizado na escala da frequiência: $\int f_{D}(v) \cdot d v=1$; Substituindo a Eq.(2.15) e (2.16) em (2.14) chega-se à famosa Equação de Förster: 


$$
k_{T}=\frac{9000(\ln 10) K^{2} \eta_{D}}{128 \pi^{5} n^{4} N_{A V} \tau_{D} R^{6}} c^{4} \int_{0}^{\infty} f_{D}(v) \varepsilon_{A}(v) \frac{d v}{v^{4}}
$$

Assumindo $\widetilde{v}=v / c$, têm-se:

$$
J=c^{4} \int_{0}^{\infty} f_{D}(v) \varepsilon_{A}(v) \frac{d v}{v^{4}}=\int_{0}^{\infty} f_{D}(\tilde{v}) \varepsilon_{A}(\tilde{v}) \frac{d \tilde{v}}{\tilde{v}^{4}}
$$

Tomando $k_{T}=1 / \tau_{D}$ obtém-se a distância critica de Förster escrita como:

$$
R_{0}^{6}=\frac{9000(\ln 10) K^{2} \eta_{D}}{128 \pi^{5} n^{4} N_{A V}} \int_{0}^{\infty} f_{D}(\tilde{v}) \varepsilon_{A}(\tilde{v}) \frac{d \tilde{v}}{\tilde{v}^{4}}
$$

Esta é a distância crítica de transferência ou raio de Förster $\left(R_{0}\right)$ que pode ser definido como a distância doador - receptor, quando a eficiência de transferência é de 50 \%, como mostrado no item 2.2.2. Para escrever a Eq.(2.17) mais convenientemente, toma-se o fator orientação:

$$
K=\cos \phi_{S A}-3 \cos \phi_{S} \cdot \cos \phi_{A}
$$

onde $\phi_{A S}$ é o ângulo entre o momento do vetor transição para ambas as moléculas enquanto $\phi_{S}$ e $\phi_{A}$ são os ângulos entre os respectivos vetores (doador e receptor) e a direção $\mathrm{S} \rightarrow \mathrm{A}$. O valor médio da distribuição aleatória é $K^{2}=2 / 3[13,33]$. 


\subsubsection{TRANSFERÊNCIA DE ENERGIA (PROCESSOS COMPLEMENTARES):}

De acordo com a teoria do processo de transferência de energia apresentada por Förster em 1959 [13], a energia $(E)$ adquirida por uma molécula doadora é transferida para uma molécula receptora num único passo. Teorias e resultados experimentais mais recentes mostram que o mecanismo de transferência é uma somatória de processos que incluem no mínimo duas etapas [34]: (1) difusão ou migração da energia de excitação entre segmentos conjugados ao longo da cadeia polimérica e (2) transferência de energia do doador para o receptor. A figura 2.9 ilustra as duas etapas envolvidas no mecanismo de transferência.

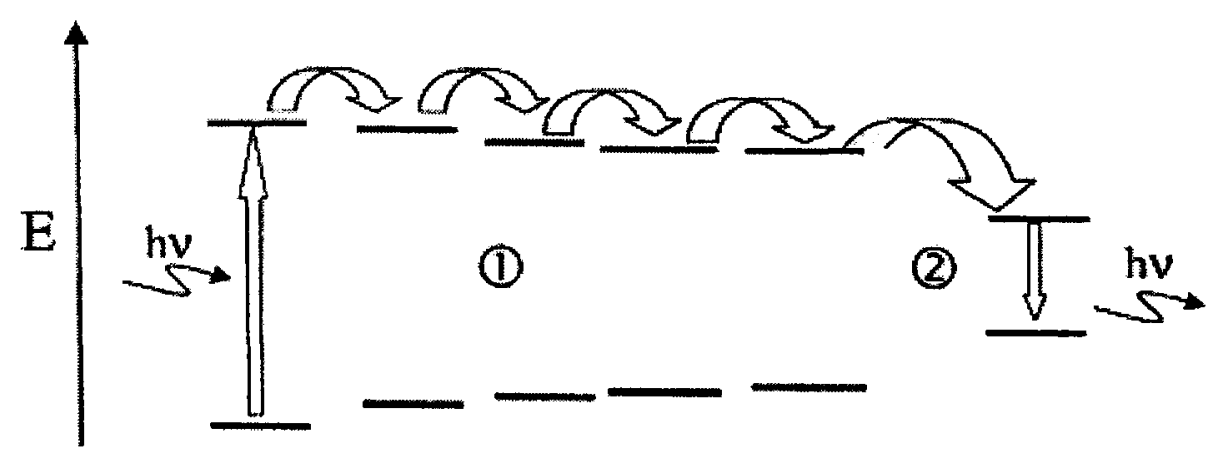

Figura 2.9: (1) Dinâmica da migração de energia (E) entre segmentos conjugados ao longo de uma cadeia polimérica conjugada e (2) entre cadeias conjugadas [34].

$\mathrm{Na}$ primeira etapa da migração de energia (entre segmentos) o processo é dependente da temperatura, pois uma das conseqüências da desordem térmica (torções, etc) provocada pelo aumento da temperatura é o deslocamento da distribuição de segmentos conjugados para graus de conjugação menores (mais detalhes item 2.2). No segundo processo independente da temperatura, a interação que ocorre entre as cadeias conjugadas é do tipo dipolo-dipolo descrito pelo processo Förster apresentado no item 2.2.3. 
Segundo Schwartz e colaboradores [35-36], a migração de energia ao longo dos segmentos da molécula é bem mais lenta (algumas ordens de magnitude) do que a transferência de energia via Förster (poucos picosegundos) entre as cadeias poliméricas. De acordo com o passo (1) ilustrado pela Figura 2.9, a migração de energia ao longo da cadeia polimérica, além de ser dependente com a temperatura, requer comunicação entre segmentos do polímero que podem estar separados pelas quebras de conjugações, levando um tempo maior para se difundir. Os resultados de Schwartz e colaboradores mostraram também que, imediatamente após a excitação, toda a emissão originária da molécula excitada apresenta alto valor de anisotropia $(r)$. Como a energia migra entre segmentos, a memória da polarização inicial é perdida (se o material for isotrópico), conduzindo à diminuição da anisotropia nos primeiros picosegundos que segue a excitação.

Outro resultado bastante interessante envolvendo migração de energia é apresentado por Rothberg [37]. Segundo seus resultados obtidos pela espectroscopia óptica de polímeros em solução, a energia de excitação é eficientemente transferida para segmentos maiores e, na maioria dos casos (75\%), os segmentos maiores são as espécies emissoras. Somente $25 \%$ de todas as moléculas apresentam transferência de energia parcial, indicada pela fraca emissão dos segmentos curtos. Quando os polímeros estão na forma de filme, a eficiência da transferência de energia para segmentos maiores é ainda mais elevada [53]. Dentro deste contexto, conclui-se que o processo Förster envolvendo transferência de energia é direcional e no sentido dos menores segmentos para os maiores. 


\section{Capítulo 3}

Material, Preparação dos filmes e Métodos Experimentais

Neste capítulo são descritos os procedimentos da síntese do poli(p-fenileno vinileno) (PPV), suas características físicas e químicas, assim como os métodos e as técnicas utilizadas para a obtenção dos filmes. Visto que o objetivo principal deste trabalho é correlacionar a estrutura morfológica dos filmes de PPV com a polarização da luz emitida, foi necessária a utilização de diversas técnicas e métodos para obtenção de filmes com ordenamentos moleculares distintos como: Casting com e sem estiramento, Langmuir - Blodgett (LB) [38], Spin - Coating (SC) [39] e Self - Assembly (S.A) [4041] com estiramento. Os equipamentos experimentais empregados na investigação das propriedades ópticas dos filmes de PPV foram: espectroscopia de absorção polarizada, fotoluminescência (PL) e um aparato experimental montado exclusivamente para o estudo do ordenamento molecular em filmes orientados luminescentes. 


\subsection{O POLI(P - FENILENO VINILENO) - PPV}

A processabilidade dos materiais poliméricos em forma de filmes finos é de fundamental importância para uma investigação científica e sistemática das propriedades ópticas e eletrônicas apresentadas por estes novos semicondutores orgânicos [42]. Estas propriedades são afetadas pelas características morfológicas dos filmes orgânicos, como a homogeneidade, comprometendo, deste modo, à reprodutibilidade dos resultados experimentais. A busca por estes novos materiais tem seu primeiro estágio nas rotas de síntese química, no qual os resultados esperados são materiais que sejam solúveis em solventes orgânicos e facilmente processáveis. $O$ poli( $p$-fenileno vinileno) (PPV) tem atraído recentemente bastante interesse, pois a sua síntese a partir da rota do precursor é relativamente simples, os filmes finos obtidos são de excelente qualidade [43-44] e apresentam propriedades de luminescência [19, 45-48].

\subsection{SÍNTESE QUÍMICA E PROPRIEDADES ÓPTICAS DO PPV}

A síntese química do poli ( $p$-fenileno vinileno) $\left(-\mathrm{C}_{6} \mathrm{H}_{4}-\mathrm{C}=\mathrm{C}-\right)_{\mathrm{n}}$ e seus derivados foi extensivamente estudada na última década. O PPV, em sua forma conjugada, não é solúvel em solventes orgânicos, o que dificulta o seu processamento direto na forma de filme. Mas foi possível desenvolver uma rota de síntese química, denominada "rota do precursor solúvel", na qual o poli(cloreto de xilideno tetrahidrotiofeno) (PTHT) precursor do o polímero, é sintetizado e facilmente processado em forma de filmes. $\mathrm{O}$ fato deste polímero precursor não ser conjugado implica na realização de uma segunda etapa de tratamento térmico para converte-lo em PPV. Neste caso, a segunda etapa é 
denominada de conversão térmica. A rota de síntese química do precursor PTHT é bem conhecida na literatura [47-50], portanto abordaremos apenas a rota da conversão do PPV (Figura 3.2). Para realizar a síntese do PPV, pesou-se inicialmente $5,6 \mathrm{mg}$ da solução de PTHT em água (Aldrich) (Figura 3.1.I) e secou-se em uma câmara de vácuo $\left(10^{-2}\right.$ Torr) à temperatura ambiente (Figura 3.1.II). Adicionaram-se $10 \mathrm{ml}$ de metanol $(\mathrm{MeOH})$ puro e agitou-se a solução por $24 \mathrm{~h}$ à temperatura de $0{ }^{\circ} \mathrm{C}$ (Figura 3.1.III).

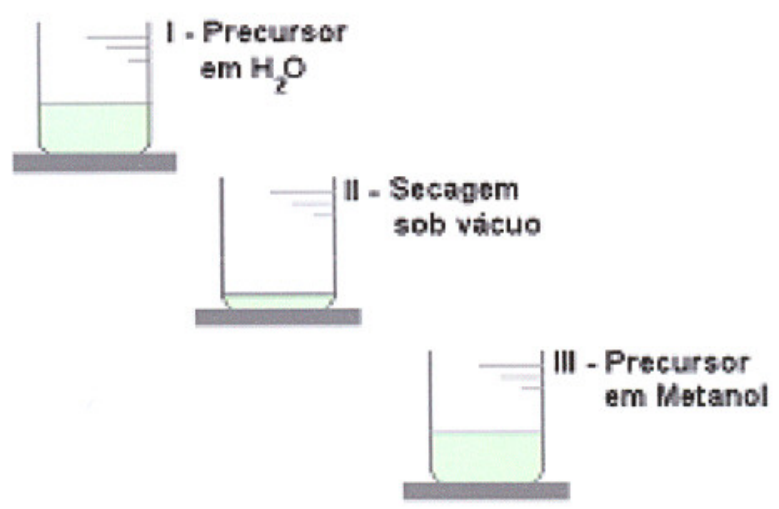

Figura 3.1: Rota de preparação da solução aquosa do precursor do PPV antes da conversão térmica.

Para realizar a síntese do PPV é necessário realizar o processo de conversão térmica, pois o polímero precursor (PTHT) tem como contra-íon o $\mathrm{Cl}$ complexado com o grupo de saída tetrahidrotiofeno bastante estável que é eliminado somente a altas temperaturas (acima de $200^{\circ} \mathrm{C}$ ). Esquematicamente, os processos de conversão térmica do PPV sintetizados a partir de uma solução precursora aquosa (PTHT) (esquematizado pela Figura 3.1) são denotados por (1) na Figura 3.2. O PPV totalmente conjugado (2) é obtido através da reação de eliminação do grupo de saída sulfồnico após tratamento térmico do filme de PTHT a $300^{\circ} \mathrm{C}$ por 6 horas (processo de conversão (i) na Figura 3.2). O grau de conversão pode ser variado através de tratamentos térmicos a temperaturas moderadas $\left(140-250^{\circ} \mathrm{C}\right)$, produzindo um copolímero com seqüências alternadas de segmentos conjugados (PPV) e não conjugados (PTHT) ao longo da cadeia polimérica. Recentemente [51], foi demonstrado a possibilidade de se produzir o mesmo copolímero (4) através da substituição parcial do contra-íon $\mathrm{Cl}$ pelo ânion de cadeia 
longa de DBS (ácido dodecilbenzenosulfonado), como ilustrado pelo processo (ii) da Figura 3.2, gerando o copolímero (3). Com o contraíon DBS, o processo de eliminação do grupo sulfônico pode ocorrer a temperaturas baixas (processo (iii) a $115^{\circ} \mathrm{C}$ ) quando comparadas ao íon $\mathrm{Cl}$ (processo padrão (i) a $300^{\circ} \mathrm{C}$ ). Com isso, foi possível produzir filmes com alta estabilidade térmica e diferente distribuições de tamanhos de segmentos conjugados com grau de conjugação médio $n_{c}$. Além disso, a variação da concentração de DBS na solução precursora permite controlar a distribuição de tamanhos de segmentos conjugados ao longo do copolímero (4) na Figura 3.2 [52].

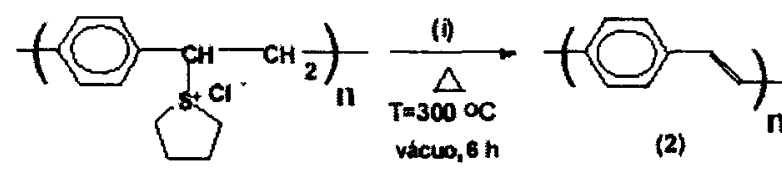

(1) vicuo, $6 \mathrm{~h}$

(2)

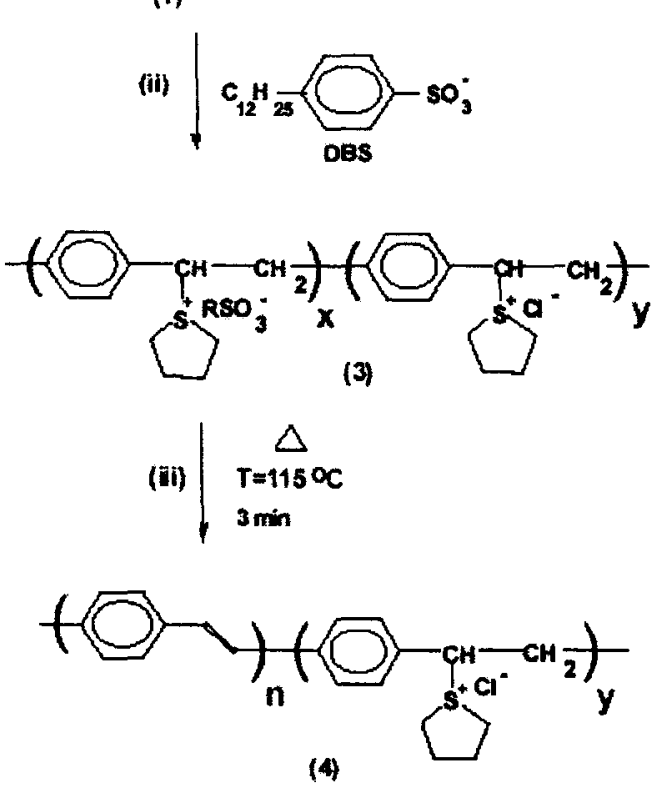

Figura 3.2: Esquema do processo de conversão do PPV. (i) Esquema da rota convencional de tratamento térmico à $300^{\circ} \mathrm{C}$ para obter PPV. (ii) Adição do DBS ao PTHT com a formação de um copolimero estatístico, tendo o tetrahidrotiofeno das unidades monoméricas complexado com o contra-ion DBS (x) e Cl (y). (iii) Processo de eliminação do grupo de saída tetrahidrotiofeno complexado com o contra-ion DBS a baixas temperaturas $\left(115^{\circ} \mathrm{C}\right)$ há tempos rápidos (3min). (Retirado da referência [52]). 
As propriedades ópticas do PPV são bastante conhecidas na literatura [53-55]. O espectro de absorção e emissão do PPV para comprimentos de onda compreendido entre $200 \mathrm{~nm}$ e $800 \mathrm{~nm}$ e está ilustrado na Figura 3.3. Observa-se que a alta absorção ocorre em $435 \mathrm{~nm}$ e o comprimento de onda emitido pelo polímero tem o pico centrado em 524 nm.

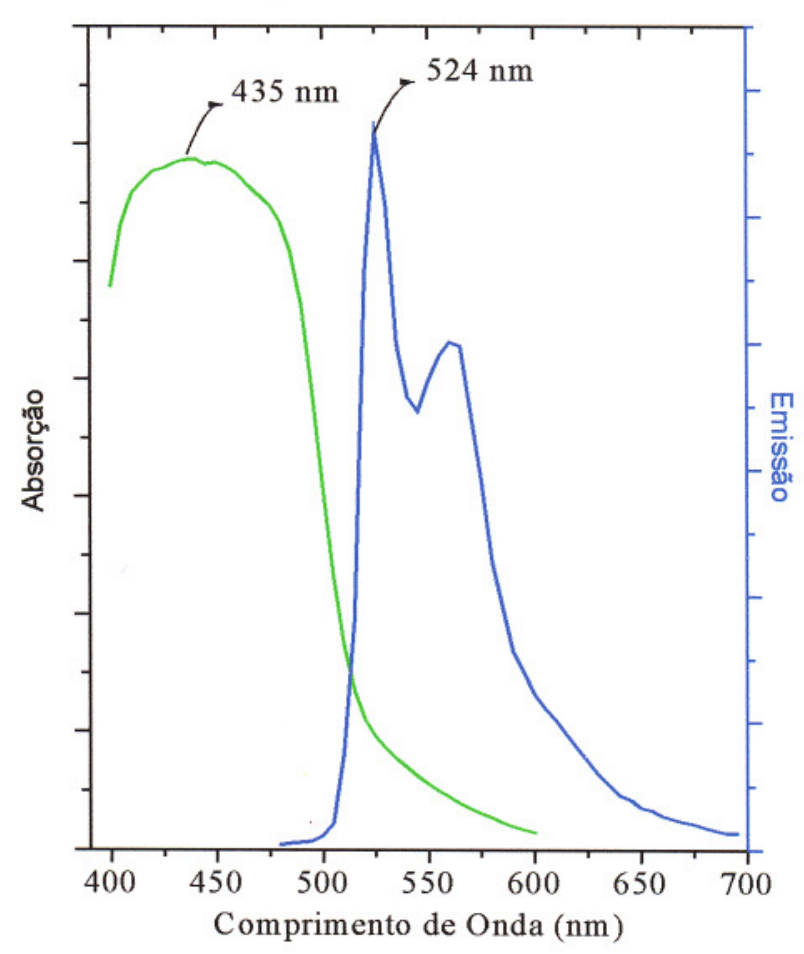

Figura 3.3: Curvas de absorção (verde) e de emissão (fotoluminescência) (azul) do $P P V$, em forma de filme mostrando as regiões de alta absorção do polímero.

O espectro de emissão foi obtido de um filme de PPV obtido pelo método Casting quando excitado com luz laser com comprimento de onde de $442 \mathrm{~nm}$. 


\subsection{PREPARAÇÃO DO FILME DE PPV:}

\subsubsection{MÉTODO CASTING:}

O método Casting de deposição de filmes consiste no espalhamento do polímero em solução sobre um substrato (lâmina de vidro) previamente limpo e hidrofilizado. A solução precursora, descrita no item 3.2 , é colocada dentro de uma seringa ou pipeta milimétrica e em seguida gotejada sobre uma das faces do substrato até que toda a área seja preenchida (Figura 3.4.1). Em seguida o substrato com a solução é colocado no interior de um forno aquecida sob vácuo para que ocorra a evaporação do solvente e a conversão do PPV como descrita pela Figura 3.2 i, restando apenas o polímero convertido sobre o substrato [56], como mostra a Figura 3.4.2.

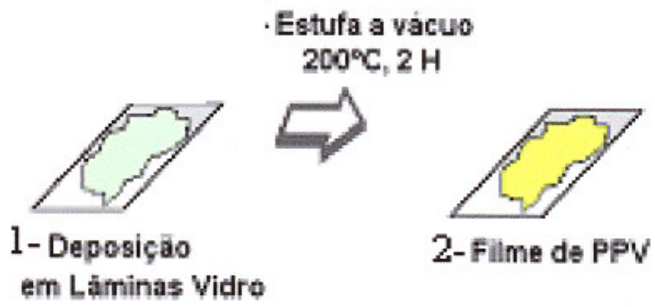

Figura 3.4: Esquema utilizado para a obtenção de filmes de PPV pelo método Casting.(1) A solução é depositada sobre o substrato e (2) aquecida á $200^{\circ} \mathrm{C}$ para que ocorra a conversão da solução precursora em PPV já na forma de filme.

Os filmes Casting não possuem qualquer tipo de ordenamento molecular devido ao fato do precursor PTHT quando solúvel em água não apresentar nenhum grau de ordenamento. Para facilitar a identificação da amostra, os filmes de PPV obtidos por esta técnica foram denominados neste trabalho por Cast-PPV. 


\subsubsection{MÉTODO CASTING COM ESTIRAMENTO}

$\mathrm{Na}$ maioria dos diodos luminescentes (LEDs), a camada fina emissora de luz tem sido preparada pelas técnicas cujos aparatos experimentais apresentam custo bastante elevado. Um método bastante simples de obter ordenamento molecular consiste em estirar mecanicamente os filmes poliméricos na direção a qual deseja-se que a molécula se alinhe [57]. Neste trabalho, preparou-se uma solução de PTHT como descrita no item 3.2 e em seguida depositou-a pelo método Casting (ver item 3.3.1) sobre uma fita de Teflon $^{\circledR}$ de comprimento x, como é mostrado em detalhe pela Figura 3.5a. Esta fita contendo a solução do precursor foi estirada mecanicamente numa única direção aplicando-se forças de sentido contrários em suas extremidades até sé obter o estiramento desejado $(x+d)$, no caso ilustrativo da Figura 3.5b. As moléculas da solução depositada sobre a fita sofrem o mesmo estiramento e se alinham na direção da força.
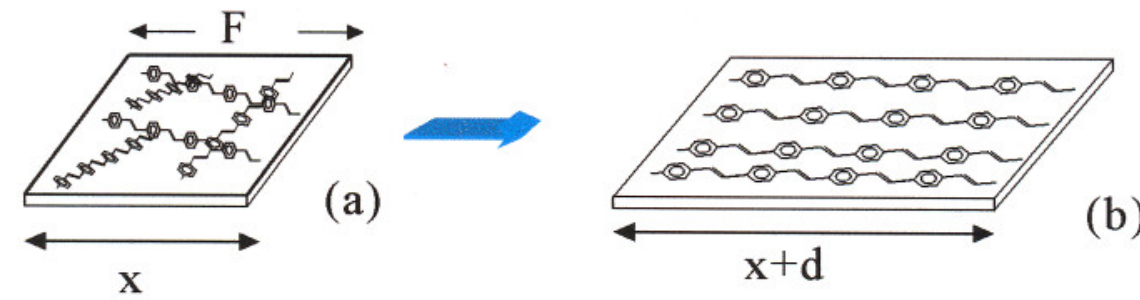

Figura 3.5: (a) Aplicam-se forças de sentido contrários numa mesma direção nas extremidades de uma fita de Teflon ${ }^{\circledR}$ contendo a solução do polimero precursor até obter o estiramento desejado. (b) Com o estiramento da fita as moléculas de polimero depositadas sobre ela se organizam de modo a se orientarem na direção da força aplicada.

Depois de estirada, a fita contendo a solução é levada ao forno para que ocorra a conversão do PPV como descrita pela Figura 3.2i, restando apenas o polímero convertido sobre a fita. Ao final desse processo o que se obtém é um filme de PPV com moléculas orientadas numa única direção por estiramento. A amostra utilizada neste trabalho foi 
produzida de acordo com a sequência descrita acima e estirada 2 vezes do seu tamanho original e foram denominados como Cast-PPV Estirado.

\subsubsection{TÉCNICA LAGMUIR-BLODGETT (LB)}

Os filmes de Langmuir são filmes monomoleculares obtidos espalhando-se uma pequena quantidade de um material constituído de moléculas anfipáticas (com uma parte hidrofilica e outra hidrofóbica) sobre uma superfície aquosa limpa. Esse material, tal como um ácido graxo ou um polímero, é inicialmente dissolvido num solvente volátil, que se evapora após a solução ser espalhada sobre a água. A camada monomolecular (filme de Langmuir) é comprimida através de barreiras móveis, as moléculas se orientam com as partes hidrofóbicas voltadas para o lado oposto da água na interface água/ar, gerando um filme altamente organizado no estado condensado. Este filme pode então ser transferido para um substrato sólido que é imerso penetrando a camada, formando o chamado filme Langmuir-Blodgett (LB), cujas características principais são a fina espessura e o alto grau de ordenamento estrutural e imersões sucessivas podem gerar filmes com várias camadas num mesmo substrato. Para a preparação de um filme de PPV por esta técnica utilizou-se um sistema convencional do tipo KSV-5000, apresentado esquematicamente pela Figura $3.6 \mathrm{em}$ uma sala limpa do tipo classe 10000. Muitos fatores influenciam na transferência de múltiplas camadas moleculares para os substratos, como por exemplo, a natureza da molécula, a estabilidade do filme de Langmuir e os parâmetros envolvendo o processo de transferência. Os filmes LB podem ser obtidos basicamente por três processos de deposição: Na subida e decida do substrato - tipo $Y$; apenas na subida do substrato - tipo $Z$ e apenas durante a imersão do substrato - tipo X. A Figura 3.7 mostra as diferentes formas de imersão dos filmes LB. A solução de deposição foi preparada através de uma composição de PTHT e do solvente DBS diluído em água $\left(10^{-4} \mathrm{M}\right)$, numa razão de $(1: 1 \mathrm{~m} / \mathrm{m})$ em 1-2diclorometano e etanol (1:1 v/v) [58]. A monocamada de Langmuir sobre a subfase aquosa (água ultrapura - Milli- 
RO 60 acoplado a um sistema Milli-Q Plus da Millipore) foi obtida através da dispersão de $800 \mu \mathrm{l}$ da solução de deposição. Após 1 hora de espera para a evaporação do solvente e estabilização da monocamada, foi realizado um experimento cíclico de compressão e descompressão da barreira, caracterizado por isotermas de pressão por área por molécula, com velocidade de $10 \mathrm{~mm} / \mathrm{min}$.

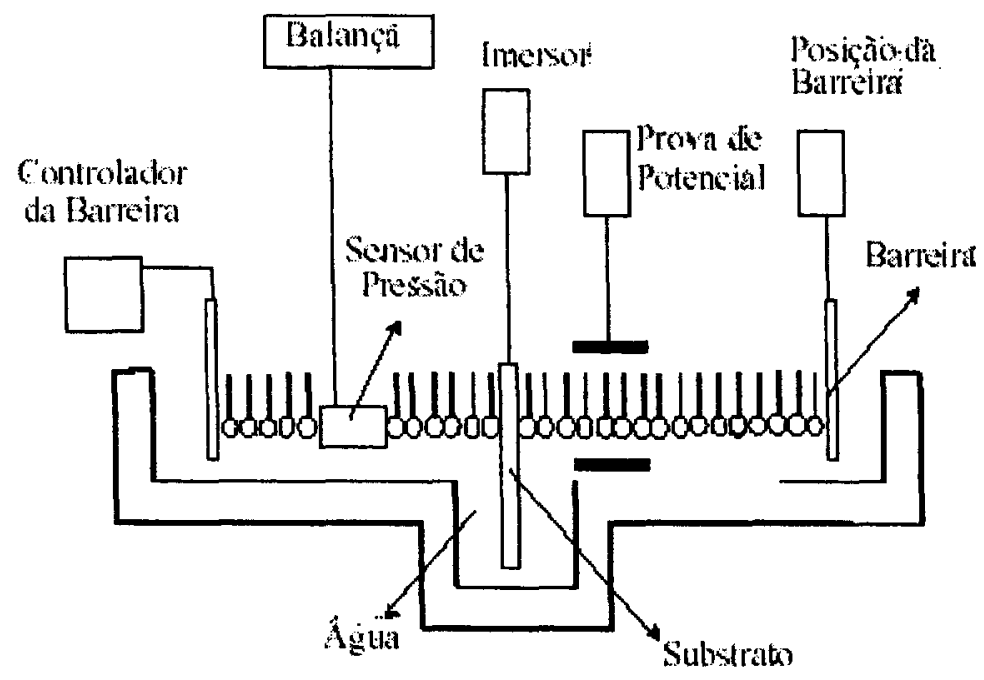

Figura 3.6: Ilustração de um sistema KSV-5000 (cuba de Langmuir) para formação de filmes de Langmuir.

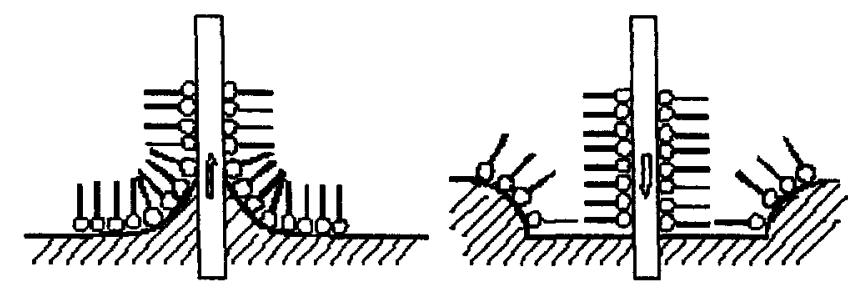

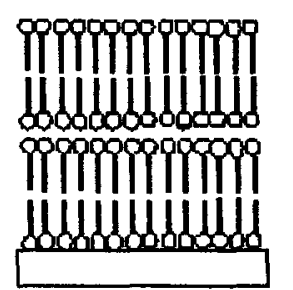

Y

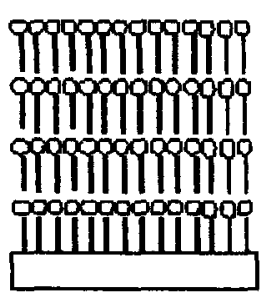

$\mathrm{x}$

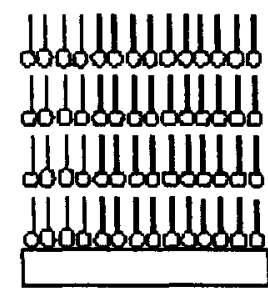

Z

Figura 3.7: Tipos de deposição de filmes $L B$. 
A Figura 3.8 ilustra a isoterma de pressão que representa esquematicamente o comportamento das moléculas, que inicialmente se encontravam na chamada fase gasosa, onde as moléculas apresentam pouca interação entre si. Aumentando-se a pressão de superfície ocorre a fase líquido-expandida onde as moléculas já interagem consideravelmente. Para maiores pressões aparece a fase condensada, na qual as moléculas encontram-se organizadas. Se a compressão for continuada além da fase condensada, haverá um colapso da monocamada, resultando em um desordenamento das moléculas. Neste estágio, o substrato ao qual deseja-se depositar o polímero é imerso a partir da superficie do líquido. Filmes Langmuir foram transferidos para o substrato (vidro) através de um processo de transferência tipo $Z$ (Figura 3.7) a uma pressão constante de $25 \mathrm{mN} . \mathrm{m}^{-1}$, velocidade de compressão das barreiras de $5 \mathrm{~mm} / \mathrm{min}$ e velocidade de imersão vertical de 2 a $4 \mathrm{~mm} / \mathrm{min}$. Os filmes LB foram posteriormente tratados termicamente (convertidos) de acordo com os procedimentos descritos pela Figura 3.2 ii.

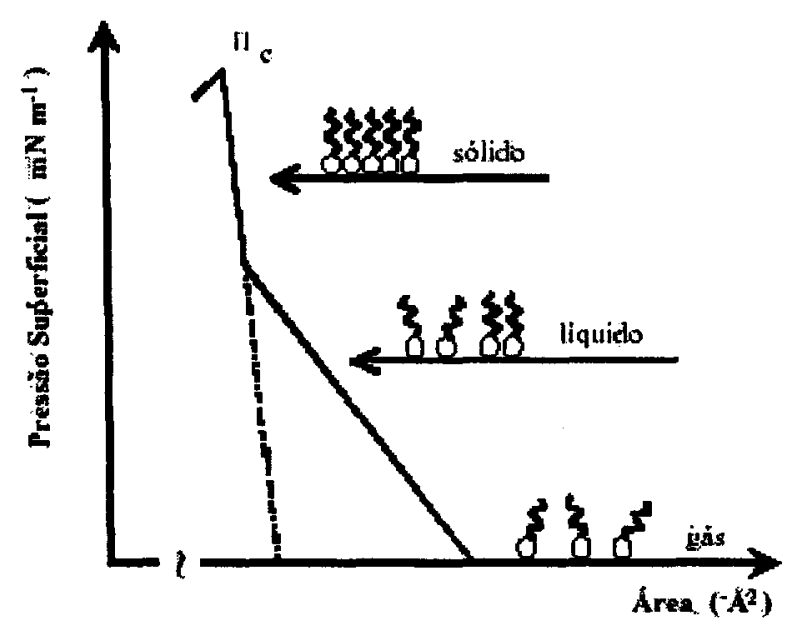

Figura 3.8: Diagrama ilustrando a isoterma de pressão.

Os filmes de PPV obtidos por esta técnica foram denominados neste trabalho por LB-PPV. 


\subsubsection{TÉCNICA SPIN-COATING (SC)}

A técnica Spin-Coating é um dos processos mais utilizados na produção de filmes finos uniformes. A produção dos filmes é feita pelo gotejamento em excesso de material (PTHT) em solução no centro do substrato que é em seguida colocado a girar com velocidade angular $(\omega)$ com ajuda de um spinner e tempo de rotação pré-definido. Os filmes poliméricos da ordem de 100 a $200 \mathrm{~nm}$ podem ser obtidos com alto grau de uniformidade e homogeneidade através do controle de aceleração e velocidade angular ( $\omega)$. Entretanto esta técnica depende de alguns fatores tais como: volatilidade do solvente, viscosidade e concentração da solução, tempo e velocidade angular de rotação. A Figura 3.9 ilustra as etapas de formação de filmes por SC: Na primeira etapa apenas a força gravitacional e as interações com substrato agem sobre a solução espalhada, que foi depositada em excesso. Na segunda etapa as forças de rotação é que dominam, do inicio da aceleração angular do substrato até atingir sua velocidade angular final. Durante este período o fluido começa a ser expelido do substrato e o filme líquido formado ainda não é uniforme. A partir deste ponto as forças viscosas começam a agir (estágio 3) e então os filmes tornam-se uniformes, pois o acúmulo do material nas bordas é ejetado na forma de gota. No último estágio o filme finalmente começa a estabilizar, o solvente evapora e então se obtém o filme [55]. Os filmes obtidos por esta técnica foram denominados Spin-PPV. 
1. Forç Ginatineionat

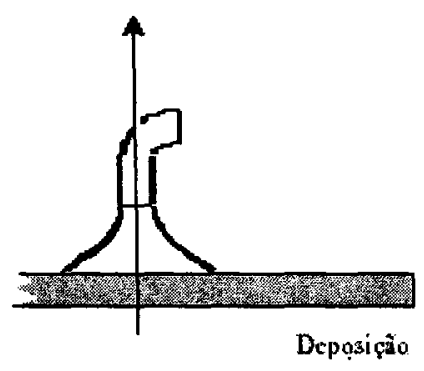

2. Força Rotacional

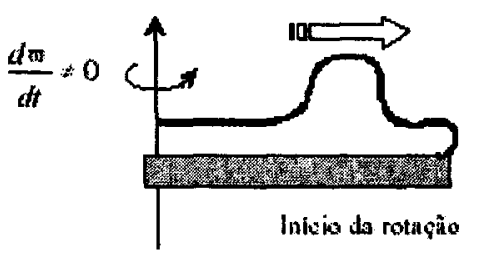

3. Força Viseosa

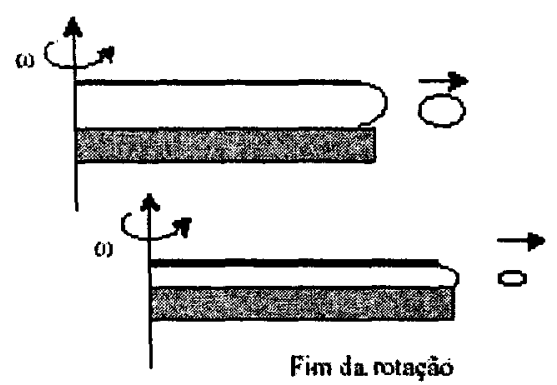

4. Eorढ̧a Centrifuģa

(1)

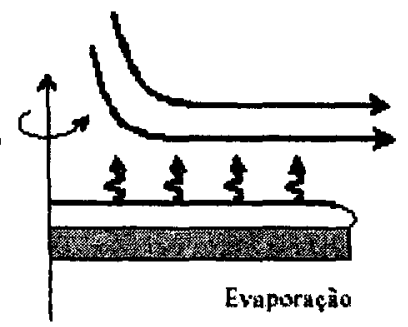

Figura 3.9: Estágios de formação de um filme por Spin-Coating.

Os filmes foram preparados em um Photo-resist spinner, modelo 1- EC101DTR484 da Hedway Research Inc. A concentração da solução de PTHT utilizada foi de 4,0 $\mathrm{mg} \cdot \mathrm{mL}^{-1}$, numa rotação de $1.000 \mathrm{rpm}$ durante $3 \mathrm{~min}$.

\subsubsection{TÉCNICA SELF - ASSEMBLY (S.A) COM ESTIRAMENTO}

Um caminho alternativo para a obtenção de filmes ultrafinos de polímeros conjugados com um alto grau de ordem é obtido através da técnica de deposição de múltiplas camadas moleculares através da técnica de automontagem (Self-Assembly, 
SA). A grande vantagem desta técnica quando comparada, por exemplo, com a técnica de produção de filmes Langmuir-Blodgett, é seu baixo custo de produção além de dispensar a utilização de uma cuba de Langmuir. Além de permitir uma incorporação seletiva de camadas poliméricas ao longo da direção do crescimento de filmes ultrafinos, a técnica de deposição por S.A apresenta ainda a vantagem de proporcionar através das mudanças das propriedades físico-químicas, tais como força iônica e pH dos materiais estudados, um controle da espessura das camadas depositadas, ou quantidade de material adsorvida. Os filmes espessos podem ser obtidos através desta técnica como descrito no esquema da Figura 3.10. Para realizar esta técnica, o substrato é previamente tratado e submerso por um tempo pré-determinado $\left(\mathrm{t}_{1}\right)$ na solução 1 contendo os policátions (cargas positivas) (Figura 3.10a). Em seguida é lavado com água ultrapura (Milli - Q). Este procedimento é repetido utilizando a solução 2 com o poliânion (cargas negativas) (Figura 3.10b) por tempo empiricamente determinado $\left(\mathrm{t}_{2}\right)$, secando-o em seguida com um fluxo de nitrogênio gasoso. A adsorção de líquidos em sólidos, através desta técnica, se dá através das interações entre solvente, soluto e substrato através atrações eletrostática com a superfície. No final é obtida uma camada dupla (bicamada) que pode ser repetida até atingir a espessura desejada. Além de polieletrólitos é possível também utilizar molécula iônicas menores.

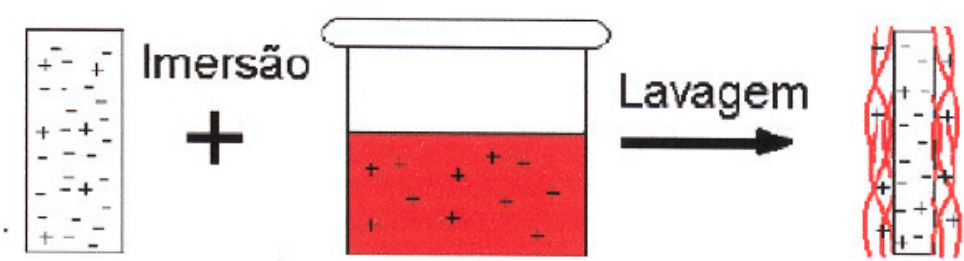

(a)
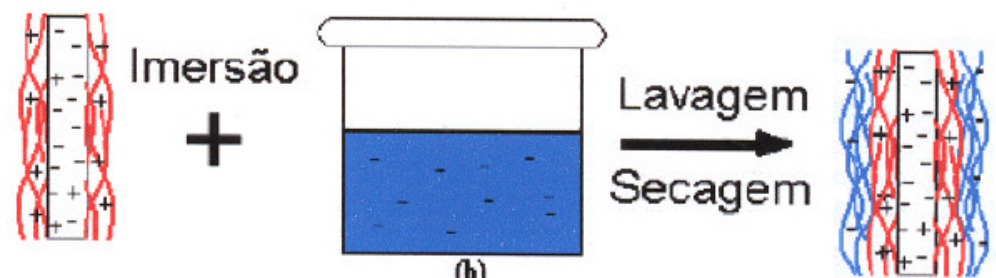

(b)

Figura 3.10: Esquema da formação dos filmes por S.A. No final do ciclo tem-se a formação de uma bicamada com espessura controlada a partir do tempo de imersão nas soluções. 
Para se obter um filme de PPV por esta técnica, preparou-se uma solução de PTHT com uma concentração de $4,0 \mathrm{mg} \cdot \mathrm{mL}^{-1}$ (solução 1) e DBS $(1: 1 \mathrm{~m} / \mathrm{m}$ ) em 1-2 diclorometano e etanol $(1: 1 \mathrm{v} / \mathrm{v})$ como solução 2 e uma fita de Teflon ${ }^{\circledR}$ fez o papel de substrato. O tempo de imersão nas soluções ( 1 e 2) foi de 1 min e meio e na água, meio minuto. Após a deposição, a fita contendo a solução é levada ao forno para converter em PPV de acordo com o esquema da Figura $3.2 \mathrm{ii}$, restando apenas o polímero convertido sobre a fita. Como a adsorção química ou física dos polímeros sobre um substrato ocorre devido à interação na interface líquido/sólido através de um empacotamento, as moléculas se encontram desordenadas. Ao final desse processo, estirou-se a fita de acordo com a Figura 3.5 do item 3.3.2 para que as moléculas do filmes se orientassem preferencialmente na direção do estiramento, e em seguida, levou-se ao forno para realizar a conversão em PPV. A amostra utilizada neste trabalho foi estirada 2 vezes do seu tamanho original e será denominada neste trabalho por S.A - PPV Estirado.

\subsection{MÉTODOS EXPERIMENTAIS}

Neste item apresentam-se os métodos experimentais utilizados para a determinação das propriedades de polarização da luz emitida pelos filmes de PPV, utilizando a espectroscopia óptica de absorção polarizada e medidas de fotoluminescência (PL) em diferentes temperaturas (10 a $300 \mathrm{~K}$ ). As medidas realizadas neste trabalho foram realizadas junto ao Laboratório de Luminescência do Grupo de Semicondutores do Instituto de Física de São Carlos. 


\subsubsection{ESPECTROSCOPIA DE ABSORÇÃO ÓPTICA POLARIZADA}

Os espectros de absorção óptica na região do ultravioleta (UV - $190 \mathrm{~nm}$ ) ao infravermelho próximo (Vis $-1100 \mathrm{~nm}$ ) foram utilizados para a verificação da absorção de luz polarizada pelos filmes orientados de poli ( $p$-fenileno vinileno) (PPV). A Figura 3.11 ilustra o sistema de medidas de absorbância do espectrômetro do tipo Hitachi U2001 do grupo de polímeros do IFSC, utilizado neste trabalho. O princípio básico de absorção óptica dos materiais é bastante simples. A luz ao passar através de um material (filme polimérico) sofre uma redução na sua intensidade. Esta redução é proporcional á intensidade incidente $\left(I_{0}\right)$ e a espessura $(d x)$ do material e pode ser escrita como [59]:

$$
d I=-\alpha \cdot I_{0} d x
$$

onde $\alpha$ é o coeficiente de proporcionalidade. Para obter a intensidade que emerge da amostra de espessura $l$, soma-se sobre todas as intensidades do lado esquerdo da equação e sobre toda a espessura do lado direito. Integrando a Eq. (3.1), observa-se que a intensidade decai exponencialmente com a espessura.

$$
I=I_{0} \cdot e^{-\alpha \cdot l}
$$

A equação (3.2) é a lei fundamental (Lei de Lambert-Beer) que governa a absorção da luz por uma amostra, freqüentemente expressa como:

$$
I=I_{0} \cdot 10 e^{-\varepsilon . l} \quad \text { ou } \quad \log \left(I / I_{0}\right)=-\varepsilon l
$$

A constante adimensional $T=I / I_{0}$ é chamada transmitância e $A=\varepsilon . l$ de absorbância da amostra escrita como: 


$$
A=\log (1 / T)
$$

onde $\varepsilon$ é chamado coeficiente de absorção molar que depende da molécula e da frequêencia da luz e sua unidade é dada pelo inverso da concentração e do comprimento $\left[\mathrm{M}^{-1} \cdot \mathrm{m}^{-1}\right]$.

De acordo com a Figura 3.11, $U V$ é a lâmpada de luz ultravioleta, Vis é a lâmpada de luz visivel, $R D$ é a rede de difração, $F_{l}$ e $F_{2}$ são fendas, $F_{i}$ filtro, $E_{l}, E_{2}, E_{3} \mathrm{e}$ $E_{4}$ são espelhos $100 \%$ reflexivos, $S E$ é o espelhos $50 \%$ reflexivo, $L_{1}$ e $L_{2}$ são as lentes e $D_{l}$ e $D_{2}$ são os detectores. $O$ feixe de referência e o feixe da amostra são denominados por $F R$ e $F A$, respectivamente, e a amostra e a referência por $A$ e $R$, respectivamente.

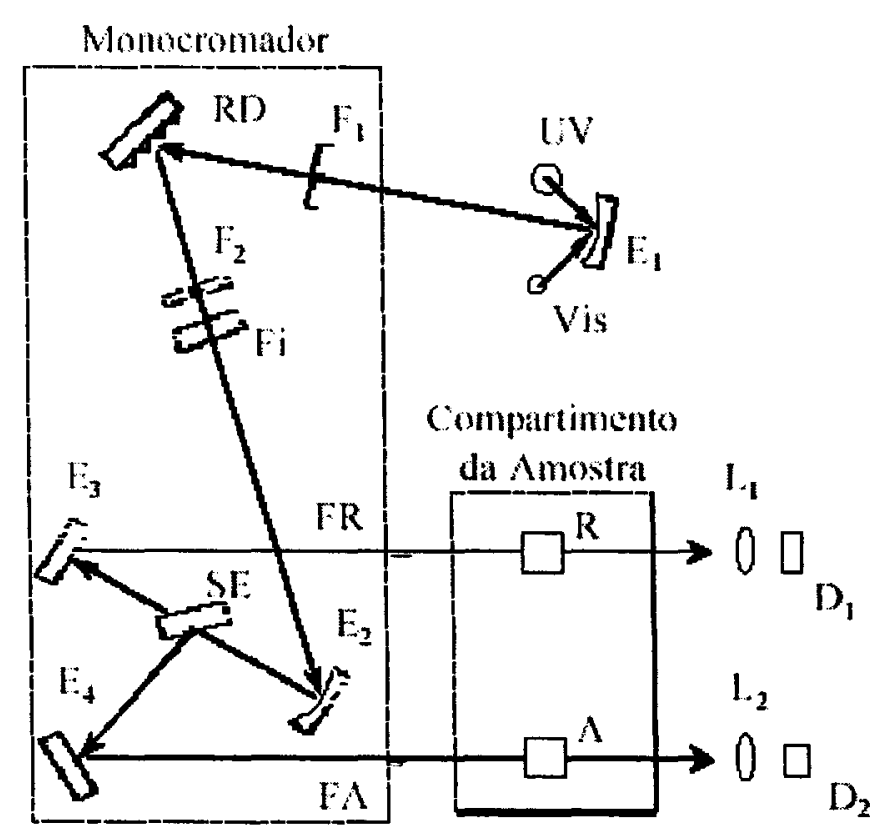

Figura 3.11: Sistema óptico do espectrômetro Hitachi U-2001 para a medida de absorção óptica polarizada.

Para realizar as medidas de absorção polarizada, dois pares de polarizadores com diferentes eixos de transmissão são inseridos (um par em cada medida) no compartimento da amostra, em frente à referência $(R)$ e à amostra $(A)$ de modo a fazer 
com que a luz emitida pela lâmpada do espectrômetro chegue polarizada à amostra. $\mathrm{O}$ primeiro par de polarizadores apresenta o eixo de transmissão paralelo à direção vertical dos filmes, fazendo com que a luz incida na direção vertical da amostra e somente as moléculas posicionadas nesta direção são responsáveis pela absorção da luz, e o segundo par com o eixo de transmissão perpendicular à direção vertical, com luz incidindo na direção horizontal da amostra de modo que a absorção da luz pelo filme seja realizada pelas moléculas posicionadas nesta direção. Através da medida de absorção polarizada, é possível verifica a absorção da luz nos dois eixos da amostra (vertical e horizontal) e determinar a anisotropia óptica de absorção dos filmes.

\subsubsection{FOTOLUMINESCÊNCIA:}

A investigação das propriedades ópticas dos filmes preparados neste trabalho foi realizada através das medidas dos espectros de fotoluminescência (PL) polarizada e em função da temperatura (10 a $300 \mathrm{~K}$ ) com o objetivo de determinar a forma da linha espectral da luz emitida pelos filmes de PPV. As medidas de fotoluminescência foram realizadas com um sistema disponível no laboratório de luminescência do Grupo de Semicondutores do IFSC. Este sistema consiste de um laser de Argônio ( $\left.25 \mathrm{~mW} / \mathrm{cm}^{2}\right)$, um monocromador $(0,5 \mathrm{~m})$ e uma fotomultiplicadora compondo o sistema de deteç̧ão (detectores), além de instrumentos ópticos para colimar e melhorar a intensidade do sinal. $\mathrm{O}$ aparato experimental está ilustrado pela Figura 3.12, nele o feixe de luz laser de comprimento de onda de $458,0 \mathrm{~nm}$ (pico de absorção do PPV) atinge a superfície da amostra que por seguinte emite luz. Essa luz é, posteriormente, colimada e captada por um monocromador e chegando na fotomultiplicadora. $\mathrm{O}$ sinal da amostra é analisado no Lock in e em seguida, o sinal da intensidade luminosa emitida em função do comprimento onda $(\lambda)$ é armazenado em um micro PC. De acordo com a Figura 3.12, o $C_{l}$ é o caminho ótico percorrido pela luz laser, $I$ é o filtro de intensidade neutra, $L_{2}, L_{3} \mathrm{e}$ 
$L_{4}$ são lentes divergentes, $P$ é um prisma isóscele, $F$ é um filtro passa alta, $C R$ é o criostato onde se variou a temperatura e o qual estão contidos as amostras, $C T$ e $V$ é o controlador de temperatura e vácuo, respectivamente. $\mathrm{O}$ porta amostra e a amostra são denominados por $P A$ e $A$, respectivamente. A fotomultiplicadora e o sinal da referência do lock-in são denominados por $P h$ e $S R$, respectivamente. Para realizar as medidas de fotoluminescência polarizada foram inseridos dois polarizadores, o primeiro responsável em polarizar a luz laser incidente na amostra, localizado entre o Chopper e a lente $L_{2}$, e o segundo localizado entre $L_{\downarrow}$ e $F$ com o papel de analisar a polarização da luz emitida pelas amostras.

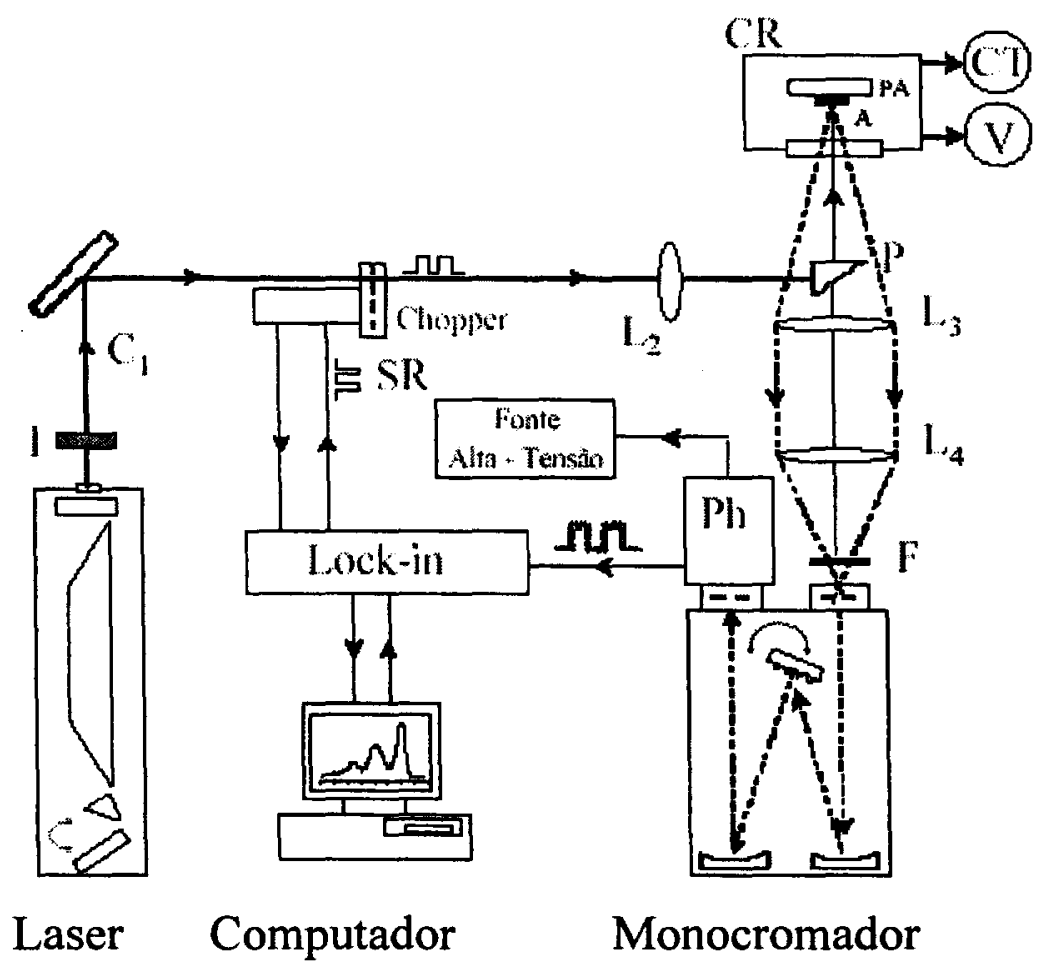

Figura 3.12: Esquema do aparato experimental para medida de fotoluminescência polarizada $e$ em função da temperatura. 


\subsubsection{DETERMINAÇÃO DA POLARIZAÇÃO DA LUZ EMITIDA:}

A ilustração do aparato experimental montado no laboratório de luminescência do Grupo de semicondutores do IFSC para a determinação das propriedades da polarização da luz emitida pelos filmes de PPV é mostrada na Figura 3.13. A luz emitida pela amostra, após ser excitada pela luz laser com comprimento de onda de $\lambda=442,0$ nm (faixa de alta absorção do PPV) com polarização linear pré-determinada pelo polarizador $\mathrm{P}_{1}$, é colimada e direcionada para o analisador (polarizador com eixo de transmissão rotatório) e em seguida para um detector, de intensidade luminosa (fototransistor), acoplado a um Lock in.

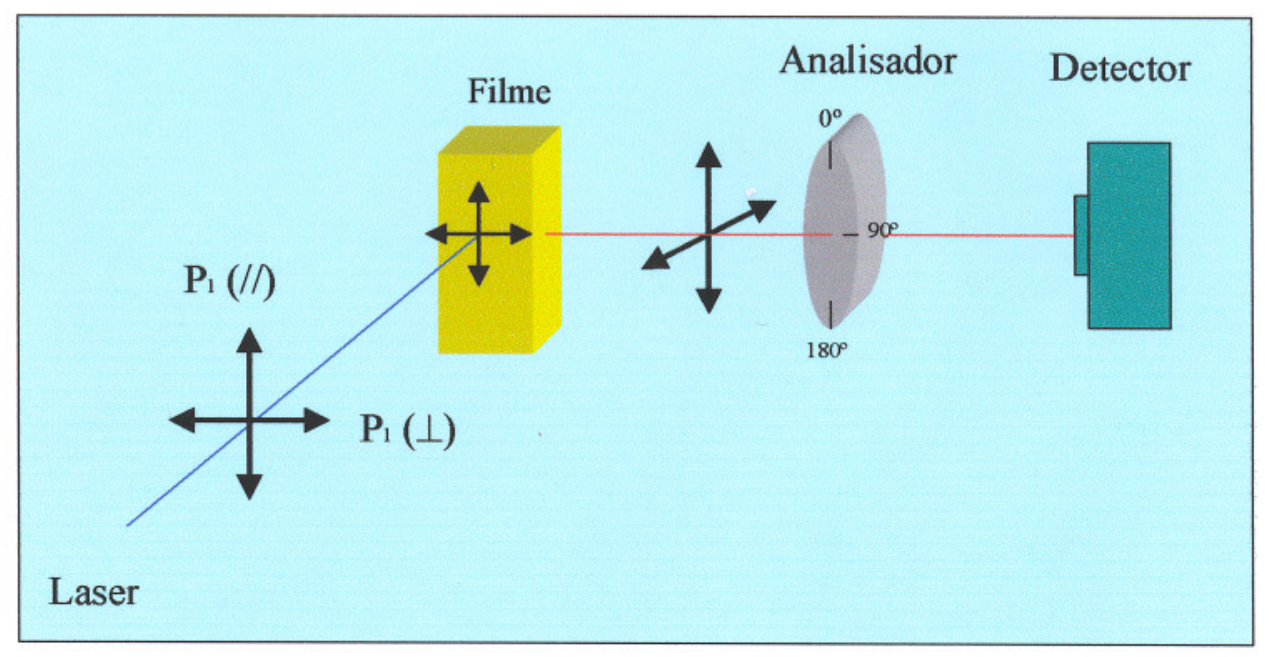

Figura 3.13: Esquema do aparato experimental montado para determinar as propriedades da polarização da luz emitida.

A direção da polarização da luz emitida pelo filme é analisada pelo polarizador rotatório (Analisador) num intervalo de ângulo de $0^{\circ}$ a $360^{\circ}$ (giro completo) e para cada ângulo o valor da intensidade luminosa (luz total emitida) é registrado pelo lock in. Através da medida da intensidade da luz em função do ângulo do analisador, é possível determinar a direção da polarização da luz emitida pelo filme para as diferentes direções de polarização da luz incidente e o grau de anisotropia óptica dos filmes. 


\section{Capítulo 4}

\section{Propriedades Ópticas dos Filmes de PPV}

As propriedades macroscópicas dos filmes poliméricos luminescentes são fortemente influenciadas pela sua anisotropia molecular. A polarização da luz emitida pelos filmes, por exemplo, possui uma relação direta com a estrutura orientada da cadeia do polimérica desses materiais [60]. Além disso, apesar do grande esforço para o entendimento das propriedades de luminescência dos polímeros emissores de luz, os processos fotofísicos envolvendo transferência de energia entre segmentos conjugados ainda são pouco compreendidos, devido à grande variedade morfológica assumidas por estes materiais. Neste capítulo são apresentados os resultados que evidenciam a influência da morfologia (ordenamento e empacotamento) molecular nos processos de transferência de energia, e também no estado final de polarização da luz emitida. Para isto, são estudadas as propriedades de absorção e emissão de filmes de PPV com diferentes morfologias e processos fotofísicos, envolvendo transferência de energia entre moléculas conjugadas. 


\subsection{1- PROPRIEDADES ÓPTICAS DE FILMES DE CASTING - PPV.}

Filmes de PPV foram preparados pelo método Casting utilizando os procedimentos descritos pelo capítulo 3, item 3.2.1. Os filmes preparados por este método têm a característica de não possuir ordenamento molecular, pois as moléculas em solução polimérica são depositadas sobre o substrato onde se orientam de modo aleatório. A espessura média dos filmes preparados pelo método casting costuma ser maior que as demais técnicas empregadas neste trabalho (da ordem de $10^{-7} \mathrm{~m}$ ). Utilizou se a espectroscopia de absorção polarizada (ver detalhes cap. 3, item 3.3.1) com o objetivo de verificar se os filmes de PPV preparados pelo método Casting apresentavam alguma anisotropia óptica de absorção. Para isso, polarizou-se linearmente a luz incidente no filme nas direções: vertical e horizontal ao eixo preferencial da amostra. A Figura 4.1 apresenta as curvas de absorção da luz com direção de polarização paralela $\left(A_{/ /}\right)$e perpendicular ao eixo vertical $\left(A_{\perp}\right)$ do filme.

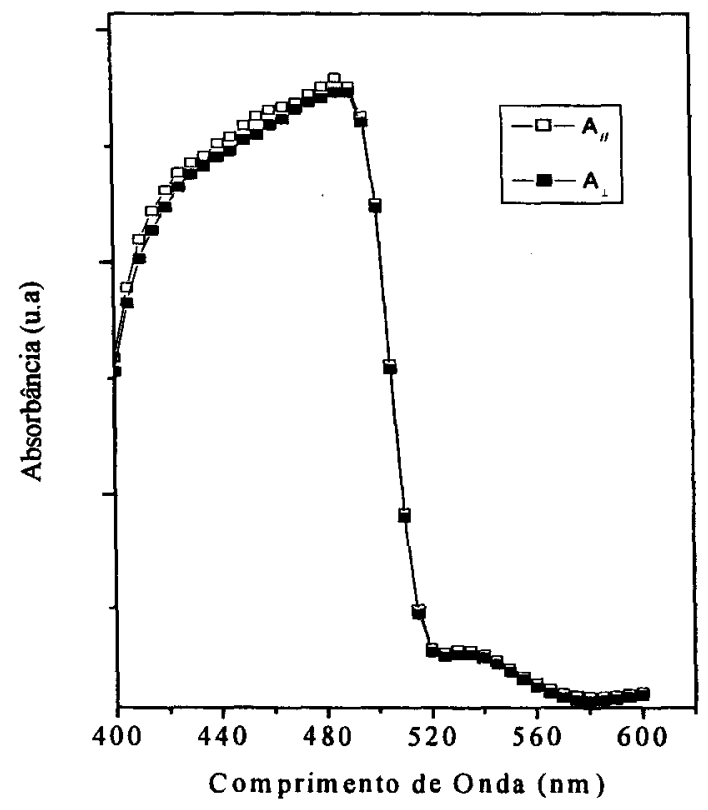

Figura 4.1: Medidas de absorbância polarizada à temperatura ambiente para o filme Cast$P P V . A_{\text {/ e }} A_{\perp}$ são as absorções nas direções de polarização da luz incidente paralelamente $e$ perpendicularmente ao eixo vertical do filme, respectivamente. 
O filme não apresentou nenhuma anisotropia óptica de absorção, pois durante a medida de absorbância polarizada (Figura 4.1) a amostra absorveu igualmente a luz incidente nos dois eixos principais (vertical e horizontal). A razão anisotrópica entre os máximos de absorção $\left(\delta=\mathrm{A}_{/ /} / \mathrm{A}_{\perp}\right)$ obtida foi cerca de 1,0 . Isto indica que este filme não apresenta anisotropia de absorção e, conseqüentemente, o valor do parâmetro de ordem molecular no plano do filme dado por $\beta=\left(A_{/ /}-A_{\perp}\right) /\left(A_{/ /}+A_{\perp}\right)$ é nulo. Observando-se os máximos no espectro de absorção com luz polarizada para o filme de PPV obtido pelo método Casting, localizados a $484,0 \mathrm{~nm}$ para orientação vertical e $489,0 \mathrm{~nm}$ para a horizontal, nota-se que os valores dos máximos de absorbâncias nos dois eixos da amostra foram bastante próximos, indicando que há uma distribuição uniforme de segmentos conjugados nos eixos do filme, desordenados em toda a área de análise.

Outra medida bastante importante para a caracterização dos filmes de PPV obtidos por este método é a fotoluminescência (PL) em função da temperatura, que diferente da medida de absorção, revela tanto o espectro da luz emitida pelo filme em um intervalo de comprimento de onda de 480 a $700 \mathrm{~nm}$ quanto à variação da forma da linha espectral. Essa medida foi feita sob vácuo num criostato onde se variou a temperatura de 10 a $300 \mathrm{~K}$. A dependência dos espectros de fotoluminescência em função da temperatura (Figura 4.2) revelou variações na forma de linha espectral, relacionadas à progressão vibracional, bastante evidente quando se compara $01^{\circ}$ pico (pico de zero-fônon) $(0 \rightarrow 0)$ com o $2^{\circ}$ pico $(1 \rightarrow 0)$ dos espectros medidos a temperatura de $60 \mathrm{~K} \mathrm{e} 120 \mathrm{~K}$. Nota-se que com o aumento da temperatura, há um aumento de intensidade da parte vibracional do espectro e um deslocamento para altas energias, ou seja, para menores comprimentos de ondas (de $530 \mathrm{~nm}$ a $9 \mathrm{~K}$ para $524 \mathrm{~nm}$ a $180 \mathrm{~K}$ ), indicadas pelas setas. 


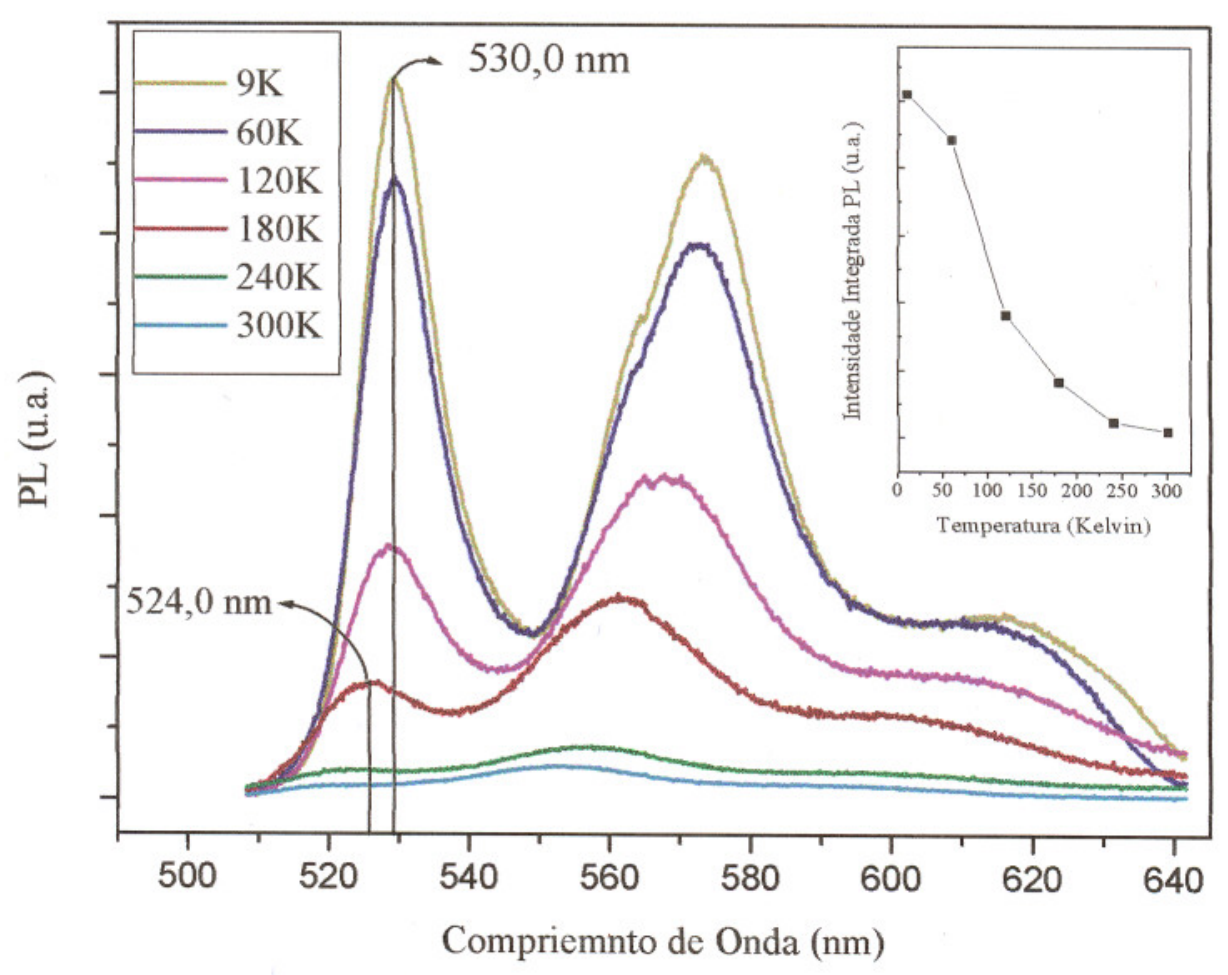

Figura 4.2: Espectros de fotoluminescência para comprimento de excitação de $442 \mathrm{~nm} \mathrm{em}$ função da temperatura da amostra Cast - PPV. As setas indicam o pico de PL para as temperaturas de $9 \mathrm{~K}$ e $180 \mathrm{~K}$ e os respectivos comprimentos de onda. Em detalhe a dependência da intensidade integrada da PL do filme Casting com a temperatura.

A variação da forma da linha espectral é uma conseqüência do deslocamento dâ distribuição de segmentos conjugados para graus de conjugação menores (causados por mudanças conformacionais relacionadas a torções [61]) devido ao aumento da desordem térmica, o que faz aumentar o acoplamento entre os estados vibracionais e eletrônicos das moléculas. Outra conseqüência do aumento da temperatura é a ativação dos caminhos não radiativos eficientes que fazem a intensidade integrada da PL diminuir, como mostra o gráfico da dependência da intensidade integrada em função da temperatura em detalhe na Figura 4.2. 
Para estudar a polarização da luz emitida pelos filmes Cast-PPV realizou-se medidas de fotoluminescência polarizada onde a configuração experimental utilizada está mostrada na Figura 4.3. Para realizar este experimento incidiu-se sobre o filme um feixe de laser de excitação $\left(\lambda_{\mathrm{ex}}=442 \mathrm{~nm}\right)$ com direções de polarização paralelo $\left(\mathrm{P}_{1}=\right.$ $(/ /))$ e perpendicular $\left(\mathrm{P}_{1}=(\perp)\right)$ ao eixo vertical da amostra, excitando deste modo os segmentos conjugados que se encontram na direção paralela e perpendicular ao eixo vertical da amostra, respectivamente. A análise da polarização da luz emitida pelo filme foi realizada colocando-se um polarizador/analisador $\left(\mathrm{P}_{2}\right)$ antes do detector nas direções paralela $\left(\mathrm{P}_{2}=(/ /)\right)$ e perpendicular $\left(\mathrm{P}_{2}=(\perp)\right)$ ao eixo vertical da amostra.

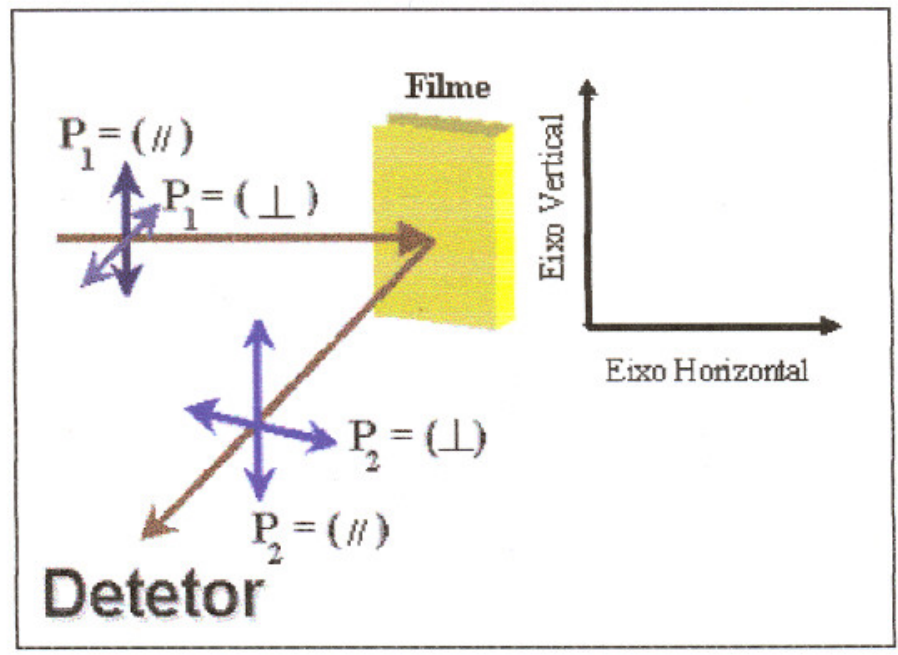

Figura 4.3: Esquema experimental para medida de fotoluminescência polarizada utilizando duas configurações de polarização da luz de excitação ou incidente $\left(P_{I}\right)$ e para o analisador $\left(P_{2}\right)$.

As medidas de fotoluminescência polarizada realizada para o filme Cast-PPV são apresentadas na Figura 4.4. 


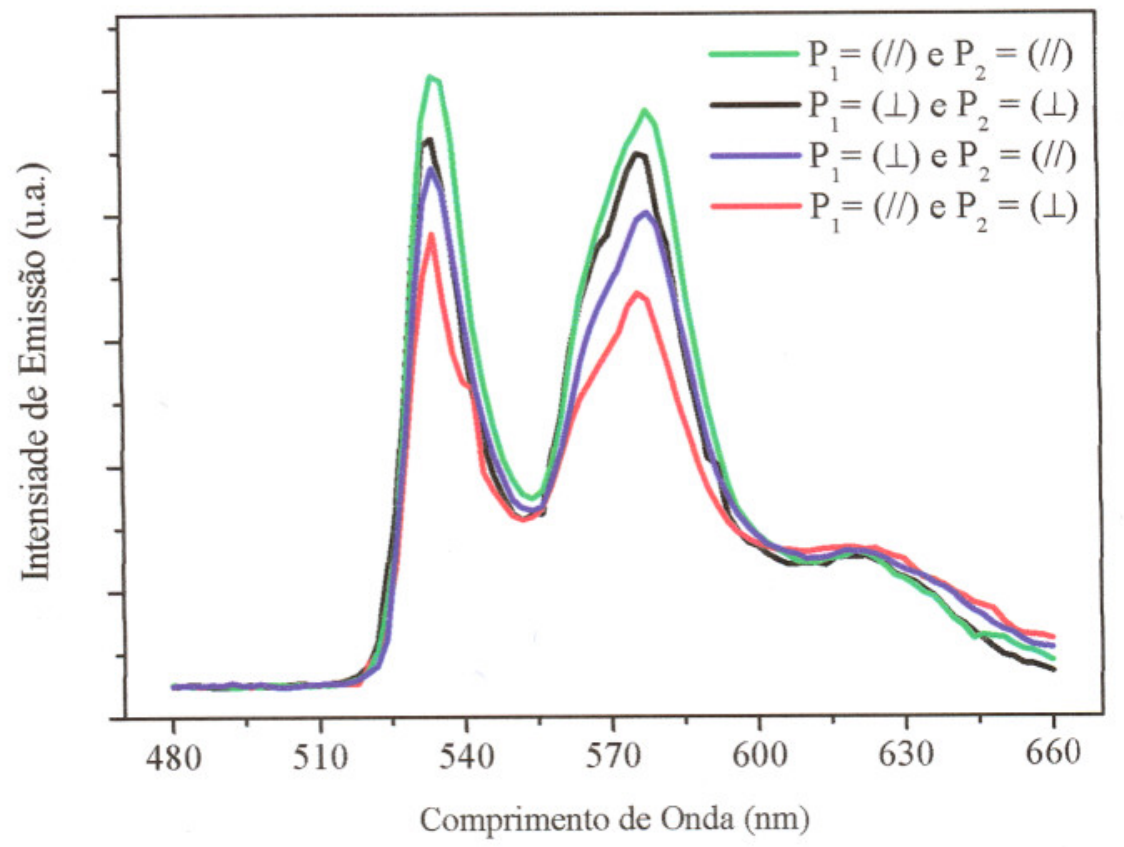

Figura 4.4: Espectro da fotoluminescência polarizada para o filme Cast-PPV à temperatura de $60 \mathrm{~K}$.

Nesta medida utilizou-se quatro configurações para a polarização da luz de excitação $\mathrm{P}_{1}\left(\lambda_{\mathrm{ex}}=442 \mathrm{~nm}\right)$ e $\mathrm{P}_{2}$. Na primeira configuração $\mathrm{P}_{1}=(/ /)$ e $\mathrm{P}_{2}=(/ /)$, a polarização da luz de excitação está paralela ao eixo vertical da amostra, tendo como objetivo excitar os cromóforos que estão posicionados na direção paralela a esse eixo. Com o polarizador $\mathrm{P}_{2}$ posicionado na mesma direção da polarização da luz incidente, o espectro de emissão obtido é devido a luz emitida com polarização paralela ao eixo vertical da amostra. Na segunda configuração $\mathrm{P}_{1}=(/ /)$ e $\mathrm{P}_{2}=(\perp)$, a polarização da luz de excitação é paralela ao eixo vertical da amostra, conseqüentemente, excitando os cromóforos posicionados paralela a esta direção. Tomando-se $\mathrm{P}_{2}$ perpendicular a esta direção, o espectro de luminescência é referente à luz emitida com polarização perpendicular à direção do eixo vertical da amostra. Na terceira configuração $\mathrm{P}_{1}=(\perp) \mathrm{e}$ $\mathrm{P}_{2}=(/ /)$, a luz de excitação está com polarização perpendicular ao eixo vertical da 
amostra e o polarizador $P_{2}$ na direção paralela, deixando passar apenas a luz emitida com polarização nesta direção. A quarta configuração $P_{1}=(\perp)$ e $P_{2}=(\perp)$, apresenta a polarização da luz de excitação perpendicular ao eixo vertical da amostra e na mesma direção se encontra posicionado o polarizador $\mathrm{P}_{2}$, permitindo a passagem somente de luz emitida com polarização perpendicular ao eixo da amostra. De acordo com os resultados mostrados na Figura 4.4, o maior valor obtido da intensidade da PL no pico de zerofônon ocorreu quando $\mathrm{P}_{1}$ e $\mathrm{P}_{2}$ estavam paralelo ao eixo vertical da amostra, nas configurações $P_{1}=(/ /)$ e $P_{2}=(\perp), P_{1}=(\perp)$ e $P_{2}=(/ /)$ e $P_{1}=(\perp)$ e $P_{2}=(\perp)$ os valores de intensidades decresceram, nesta ordem, quando observadas no $1^{\circ}$ pico (zero-fônon, 538 $\mathrm{nm}$ ). A variação de intensidade em $538 \mathrm{~nm}$ foi pequena o suficiente para caracterizar o filme como fracamente anisotrópico com valor da razão de intensidade, medida na configuração $\left(\mathrm{P}_{1}=(/ /)\right.$ e $\left.\mathrm{P}_{2}=(/ /)\right)$ e $\left(\mathrm{P}_{1}=(/ /)\right.$ e $\left.\mathrm{P}_{2}=(\perp)\right)$ no pico de zero-fônon, de 1,3 . Com a direção da polarização da luz de excitação $\left(P_{1}\right)$ paralela ao eixo vertical da amostra, mediu-se o valor da componente vertical de intensidade da luz emitida pelo filme, $I_{V}$, medida com o polarizador $P_{2}$ paralelo à direção da polarização de excitação $e$ da componente horizontal, $\mathrm{I}_{\mathrm{H}}$, medida com o polarizador $\mathrm{P}_{2}$ perpendicular à direção de excitação. Assim, calculou-se o valor da anisotropia de emissão dada por $r=\left(I_{V}-I_{H}\right)$ / $\left(\mathrm{I}_{\mathrm{V}}+2 \mathrm{I}_{\mathrm{H}}\right)[28,62]$ para o filme Cast-PPV, no pico de zero-fônon, o valor encontrado foi de 0,099 .

Outra maneira de confirmar a anisotropia desse filme de PPV pode ser feita a partir do estudo da polarização da luz por ele emitida, utilizando-se a montagem experimental ilustrada no capítulo 3 , item 3.2.3. Nesta montagem, a amostra foi excitada através de luz laser $\left(\lambda_{\mathrm{ex}}=442 \mathrm{~nm}\right.$ ) com duas direções de polarização, primeira paralela $\mathrm{P}_{1}(/ /)$ e depois perpendicular $\mathrm{P}_{1}(\perp)$ ao eixo vertical da amostra. Para cada direção da polarização da luz de excitação variou-se o ângulo do analisador $\left(\mathrm{P}_{2}\right)$, um polarizador rotatório de $0^{\circ}$ a $360^{\circ}$ e para cada ângulo mediu-se o valor da intensidade da luz total emitida pela amostra à temperatura ambiente (300 K). A Figura 4.5 apresenta o gráfico da intensidade de emissão total normalizada para as duas direções de polarização da luz de excitação (linha preta para a polarização paralela e linha azul para a polarização 
perpendicular ao eixo da amostra) em função do ângulo do analisador em relação ao eixo vertical da amostra.

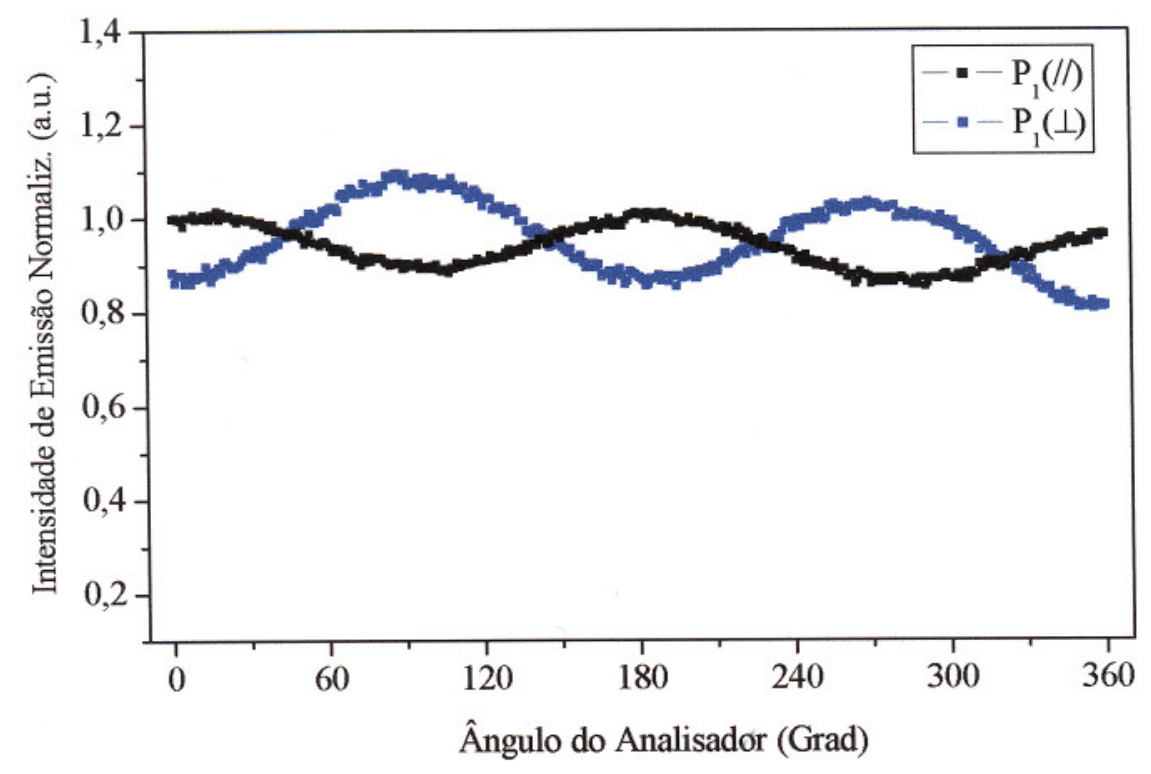

Figura 4.5: Medida da polarização da luz emitida pelo filme Cast-PPV. O Gráfico mostra a intensidade da luz emitida normalizada em função do ângulo do analisador $\left(0^{\circ}\right.$ a $\left.360^{\circ}\right)$ para as duas direções da polarização da luz de excitação, $P_{1}(/ /)$ paralelo e $P_{2}(\perp)$ perpendicular ao eixo vertical da amostra.

Num filme tipicamente desordenado os segmentos com diferentes tamanhos de conjugação se encontram distribuídas aleatoriamente em todo seu espaço. A polarização resultante da luz emitida assume assim a direção do eixo maior das moléculas (referente ao esqueleto da cadeia polimérica), desta forma é de se esperar que em um filme desordenado a luz emitida apresente polarização em todas as direções. Como há um número de moléculas suficientemente grande, a intensidade de emissão permanece constante para todos os ângulos do analisador $\left(\mathrm{P}_{2}\right)$, independente da direção de polarização da luz de excitação. No entanto, na medida da polarização da luz emitida em função do ângulo do analisador para o filme Cast-PPV foi observada uma pequena variação da intensidade de emissão para as duas direções de polarização da luz de excitação $\left(\mathrm{P}_{1}\right)$ em função do ângulo do analisador, como mostrado pela Figura 4.5. Para 
a polarização da luz de excitação na direção paralela ao eixo vertical da amostra, notouse que os máximos de intensidade da luz emitida ocorreram quando o analisador estava posicionado em $0^{\circ}, 180^{\circ}$ e $360^{\circ}$, justamente na direção de polarização da luz de excitação, conservando a direção de polarização entre a luz incidente e a luz emitida. $O$ mesmo efeito foi observado para a polarização da luz de excitação perpendicular ao eixo vertical da amostra, no qual os máximos de intensidade ocorrerem nos ângulos $90^{\circ} \mathrm{e}$ $270^{\circ}$ (direção de polarização da luz incidente), caracterizando a emissão de luz linearmente polarizada na direção perpendicular ao eixo vertical da amostra. As duas curvas da Figura 4.5 são coerentes e indicam que o filme apresentou uma leve anisotropia de emissão. Uma possível hipótese para explicar o efeito da variação da intensidade luminosa em função do ângulo do analisador se encontra no item 4.2, o qual leva em consideração o tipo de mecanismo de transporte que provavelmente ocorreu entre as moléculas (doadoras e receptoras) com a morfologia do filme.

\subsection{2- PROPRIEDADES ÓPTICAS DE FILMES DE SPIN - PPV.}

A técnica Spin-Coating é um processo bastante eficiente na produção de filmes finos (de 100 a $200 \mathrm{~nm}$ ) e uniformes. A qualidade dos filmes de PPV preparados por esta técnica foi estudada com mais detalhes através de medidas de absorção polarizada em temperatura ambiente, para verificar a anisotropia de absorção do filme. A Figura 4.6 apresenta as curvas de absorção de luz linearmente polarizada na direção paralela $\left(A_{/ /}\right)$e perpendicular $\left(\mathrm{A}_{\perp}\right)$ ao eixo vertical da amostra à temperatura ambiente. 


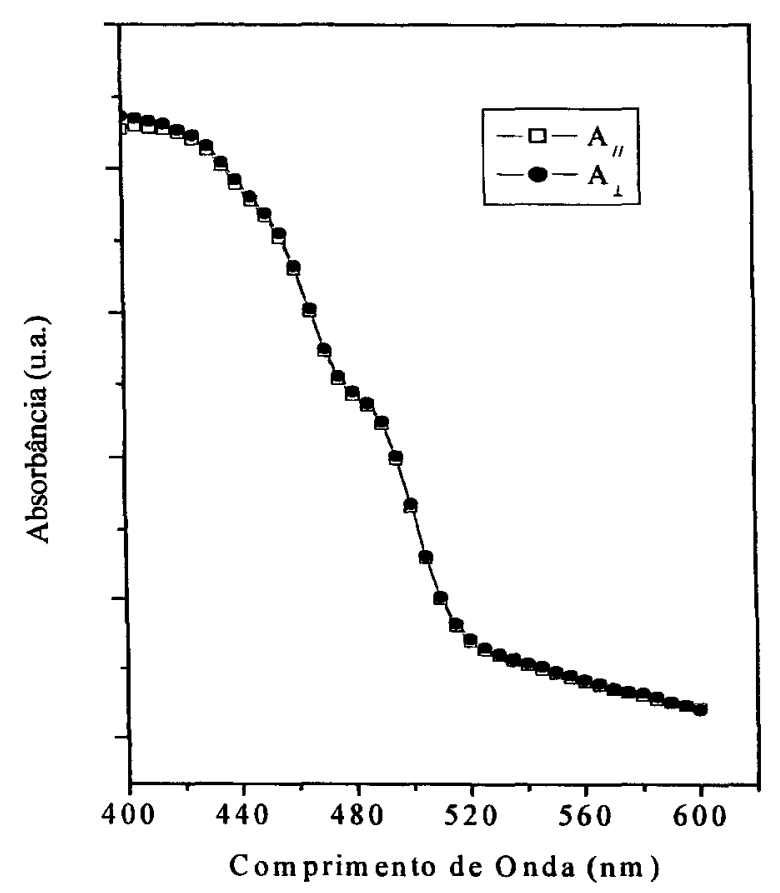

Figura 4.6: Medidas de absorbância polarizada à temperatura ambiente para o filme Spin$P P V . A_{/ /}$e $A_{\perp}$ são, respectivamente as absorções nas direções de polarização da luz incidente paralelamente e perpendicularmente à direção de estiramento do filme.

Como se pode observar, o filme Spin-PPV não apresentou nenhuma anisotropia de absorção. O grau de orientação caracterizado pela razão anisotrópica $(\delta)$ entre os máximos de absorção foi de praticamente 1,0, mostrando que este filme absorve igualmente luz nos dois eixos principais da amostra (vertical e horizontal) o que resultou a um valor nulo para o parâmetro de ordem molecular no plano do filme $(\beta)$. 
A medida de fotoluminescência (PL) a diferentes temperaturas (10 a $300 \mathrm{~K})$ para esta amostra está mostrada na Figura 4.7, no qual se encontra em detalhe o gráfico de intensidade integrada da PL em função da temperatura.

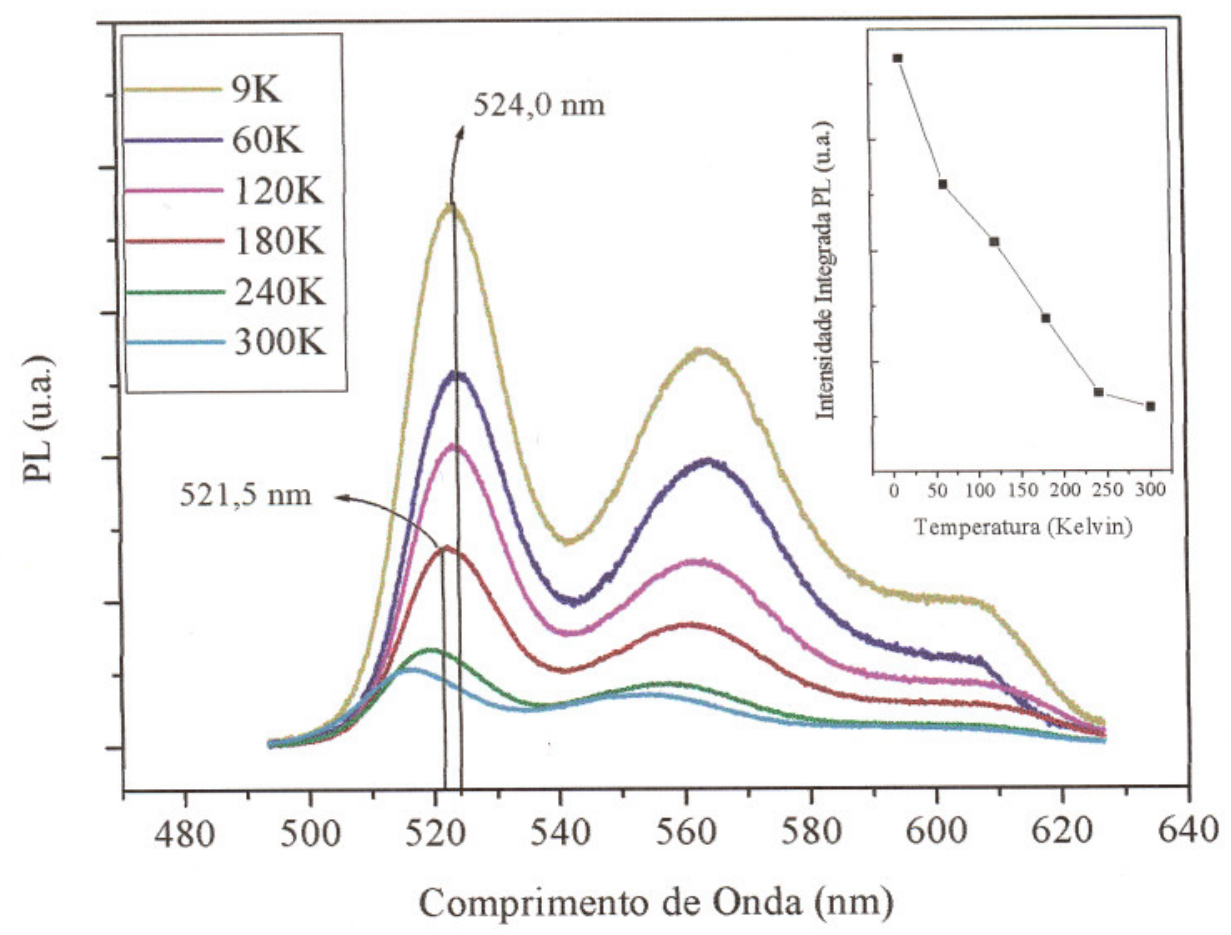

Figura 4.7: Espectros de fotoluminescência para comprimento de excitação de $442 \mathrm{~nm}$ em função da temperatura para filme Spin - PPV. As setas indicam o pico de PL para as temperaturas de $9 \mathrm{~K}$ e $180 \mathrm{~K}$ e os respectivos comprimentos de onda. Em detalhe a dependência da intensidade integrada da PL em função da temperatura.

De acordo com a Figura 4.7, a dependência dos espectros de fotoluminescência com a temperatura mostraram que houve variações da forma de linha espectral do filme relacionada à progressão vibracional e também um deslocamento do $1^{\circ}$ pico de zerofồnon de $524 \mathrm{~nm}$ para $521 \mathrm{~nm}$ numa variação de temperatura de $170 \mathrm{~K}$ para altas energias, ou seja, para menores comprimentos de onda. Tal efeito era esperado devido à redistribuição de segmentos conjugados para graus de conjugações menores em conseqüência do aumento da desordem térmicas, como torções e enovelamentos. 
Aumentando-se a temperatura, a conjugação média efetiva da cadeia polimérica deve diminuir fazendo aumentar a energia do Gap e, conseqüentemente, diminuir o comprimento de onda emitido.

A Figura 4.8 mostra os resultados da medida de fotoluminescência polarizada obtidos a $60 \mathrm{~K}$ para luz incidente polarizada linearmente na direção paralela e perpendicular ao eixo vertical da amostra Spin-PPV. Neste caso, não se observaram mudanças de intensidade e na forma de emissão quando a orientação do polarizador $\left(\mathrm{P}_{1}\right)$ e analisador $\left(\mathrm{P}_{2}\right)$ estavam dispostos paralelamente. Isto mostra inicialmente, que não há uma direção preferencial para os segmentos com maiores graus de conjugação, estando igualmente distribuídas no plano do filme. Entretanto, quando o polarizador e o analisador estão cruzados (direções opostas), a intensidade da PL cai, apesar de manter a mesma forma de emissão.

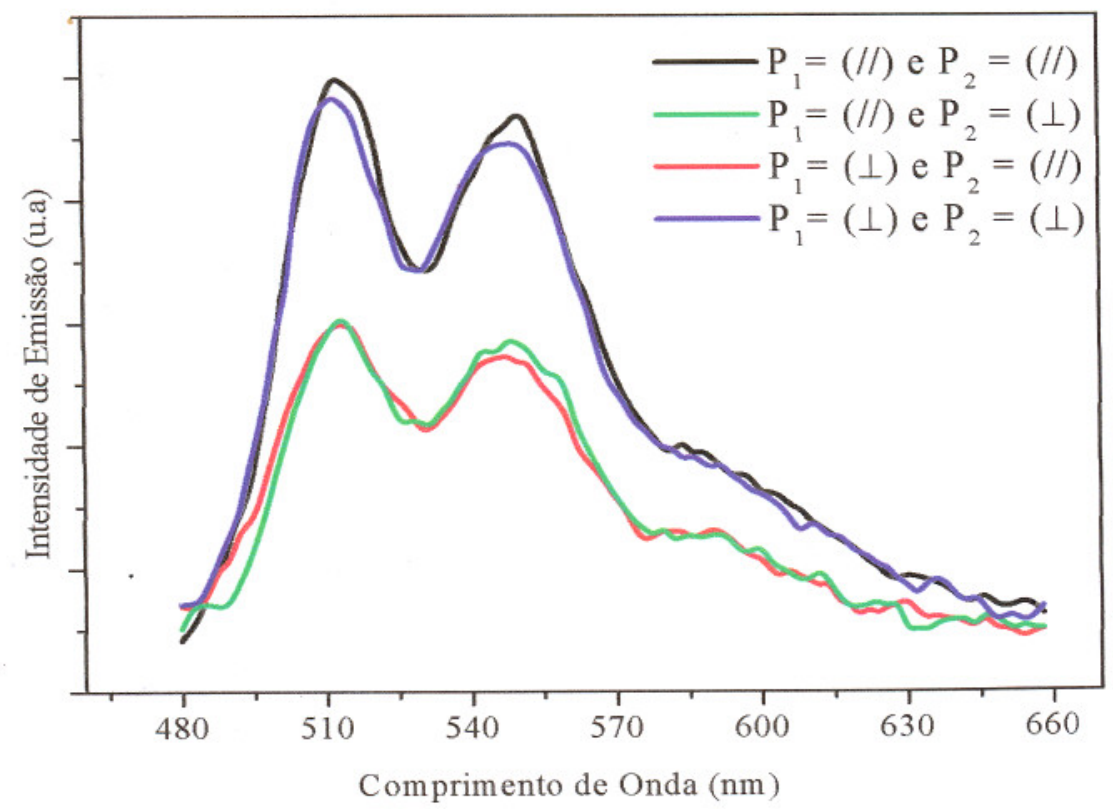

Figura 4.8: Espectro da fotoluminescência polarizada para o filme Spin-PPV a temperatura de $60 \mathrm{~K}$, para diferentes configurações da polarização da luz de excitação $P_{1}$ $\left(\lambda_{e x}=442 \mathrm{~nm}\right)$ e de emissão $P_{2}$. 
Numa primeira análise, poder-se-ia supor que no caso de polarizadores cruzados, a emissão medida deveria se extinguir. $\mathrm{O}$ fato de isso não ocorrer é um indício de que há transferência de energia entre as moléculas do filme. O valor da razão de intensidade medida entre a configuração $\left(\mathrm{P}_{1}=(/ /)\right.$ e $\left.\mathrm{P}_{2}=(/ /)\right)$ e a $\left(\mathrm{P}_{1}=(/ /)\right.$ e $\left.\mathrm{P}_{2}=(\perp)\right)$ no pico de zero-fônon $(512,0 \mathrm{~nm})$ foi de 1,65. O valor da anisotropia de emissão $r=\left(\mathrm{I}_{\mathrm{V}}-\mathrm{I}_{\mathrm{H}}\right) /\left(\mathrm{I}_{\mathrm{V}}+\right.$ $\left.2 \mathrm{I}_{\mathrm{H}}\right)=0,18$, medido no pico de zero-fônon.

$\mathrm{Na}$ seqüência deste estudo, utilizou-se a montagem experimental ilustrada no capítulo 3, item 3.2.2. O gráfico da intensidade de emissão normalizada em função do ângulo do analisador para as polarizações da luz incidente paralela e perpendicular, é mostrado pela Figura 4.9.

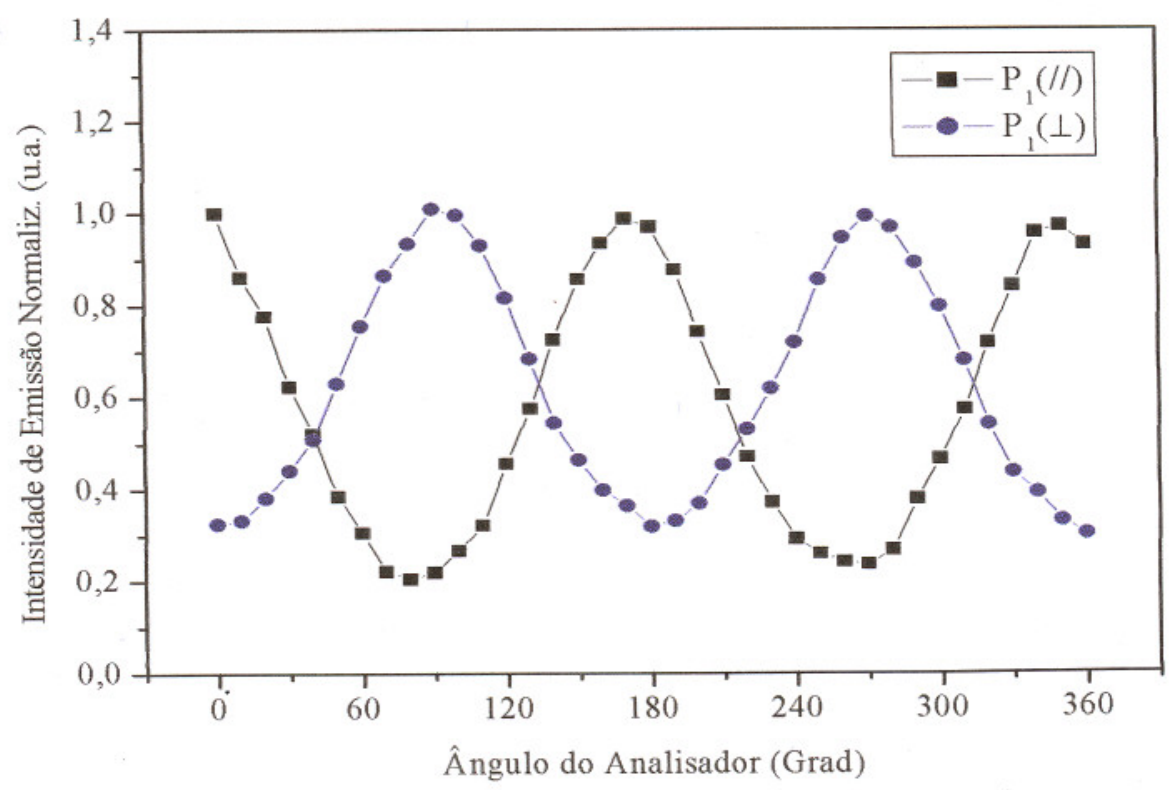

Figura 4.9: Medida da polarização da luz emitida pelo filme Spin-PPV. O Gráfico acima mostra a intensidade da luz emitida normalizada em função do angulo do analisador $P_{2}$ num intervalo $0^{\circ}$ a $360^{\circ}$, para as duas direções da polarização da luz de excitação, $P_{1}$ (//) paralelo e $P_{2}(\perp)$ perpendicular à direção do eixo vertical da amostra.

De acordo com o resultado da medida de polarização da luz emitida da Figura 4.9, observou-se uma grande variação da intensidade de emissão em função do ângulo do analisador para as duas direções de polarização da luz de excitação, mostrando que o 
filme apresenta comportamento anisotrópico. Na primeira configuração, com a polarização da luz incidente paralela ao eixo vertical da amostra, a polarização da luz emitida foi linear e paralela à direção do eixo vertical da amostra, com máximos de intensidade em $0^{\circ}, 180^{\circ}$ e $360^{\circ}$. Na segunda configuração, com a polarização da luz incidente perpendicular à direção vertical da amostra, a luz emitida apresentou direção de polarização perpendicular à direção vertical da amostra, apresentando máximos de intensidade em $90^{\circ}$ e $270^{\circ}$. O resultado foi semelhante ao observado nos filmes CastPPV, porém a variação da intensidade entre picos e vales é bem mais acentuada. Observou-se também, que a direção da polarização da luz emitida foi conservada para ambas as configurações da polarização da luz incidente (vertical e horizontal). $O$ comportamento da direção da polarização é explicado em detalhes no item 4.2, correlacionando o mecanismo de transporte ocorrido entre as moléculas com o ordenamento molecular apresentado pelo filme.

\subsection{3- PROPRIEDADES ÓPTICAS DE FILMES DE CASTING - PPV ESTIRADO.}

Dispositivos poliméricos capazes de emitir luz linearmente polarizada são necessários na indústria da informação. Recentemente, o primeiro diodo emissor de luz polarizada foi obtido a partir de um filme de Politiofeno orientado por estiramento apresentou uma razão de 3,1 entre a intensidade da luz emitida paralela e perpendicular à direção do estiramento [14]. A facilidade em se obter materiais anisotrópicos por estiramento é uma característica única dos polímeros, em particular, as técnicas de orientação molecular por meio de estiramento mecânico mostram ser bem simples, de baixo custo e tão eficazes quanto às técnicas mais sofisticadas. Prepararam-se então filmes estirados de PPV obtido pelo método Casting de acordo com os procedimentos 
descritos no capítulo 3, no item 3.2.2, tendo como substrato uma membrana de Teflon (PVDF).

Para analisar as propriedades ópticas de absorção do filme Cast-PPV Estirado, utilizou -se a espectroscopia de absorção polarizada descrita no capítulo 3, item 3.3.1. A Figura 4.10 apresenta as curvas de absorção de luz linearmente polarizada na direção paralela $\left(\mathrm{A}_{/ /}\right)$e perpendicular $\left(\mathrm{A}_{\perp}\right)$ à direção de estiramento da amostra a temperatura ambiente.

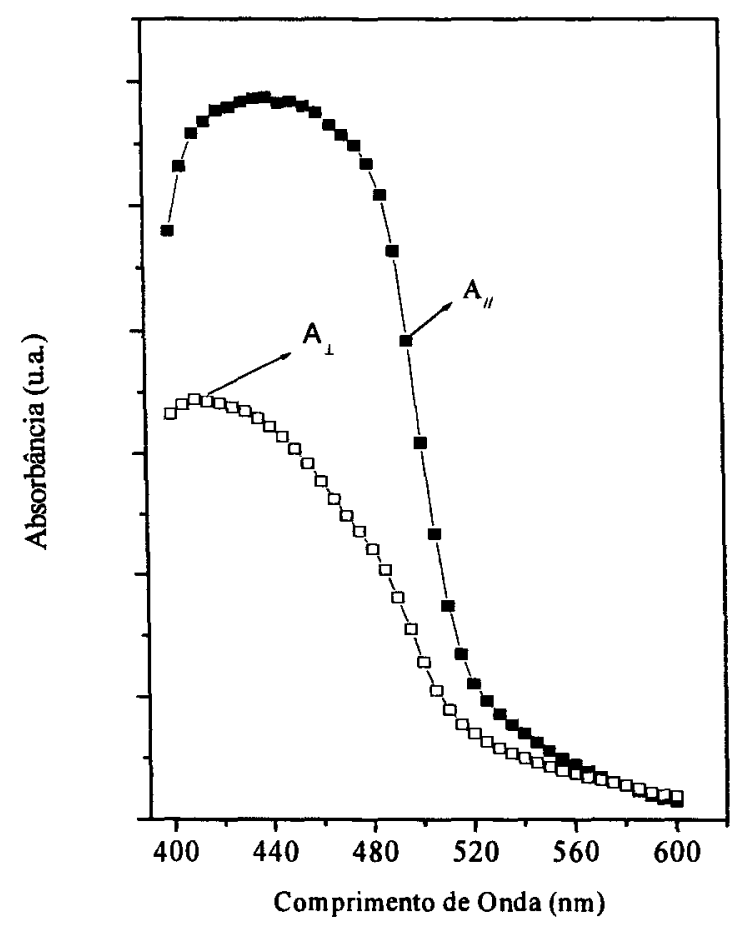

Figura 4.10: Medidas de absorbância polarizada à temperatura ambiente para o filme CastPPV estirado. $A_{\text {, }}$ e $A_{\perp}$ são as absorções nas direções de polarização da luz incidente paralelamente e perpendicularmente à direção de estiramento do filme, respectivamente.

Nota-se que a absorção do filme foi maior quando a luz incidente possuía polarização na direção do estiramento do filme, o que se conclui que o filme apresentou anisotropia de absorção. O grau de orientação caracterizado pela razão anisotrópica $(\delta)$ entre os máximos de absorção foi de 1,6, ou seja, $60 \%$ maior do que o obtido com o 
entre os máximos de absorção foi de 1,6, ou seja, $60 \%$ maior do que o obtido com o filme Casting não estirado (Figura 4.1). Este resultado mostra que o filme apresentou dicroísmo linear e a amostra apresenta anisotropia de absorção na direção do estiramento. $\mathrm{O}$ valor do parâmetro de ordem molecular no plano do filme $(\beta)$ foi 0,22 para esta amostra estirada de PPV.

A medida de fotoluminescência (PL) em diferentes temperaturas (10 a $300 \mathrm{~K}$ ) está ilustrada na Figura 4.11, onde também é mostrado em detalhe o gráfíco de intensidade integrada da PL em função da temperatura.

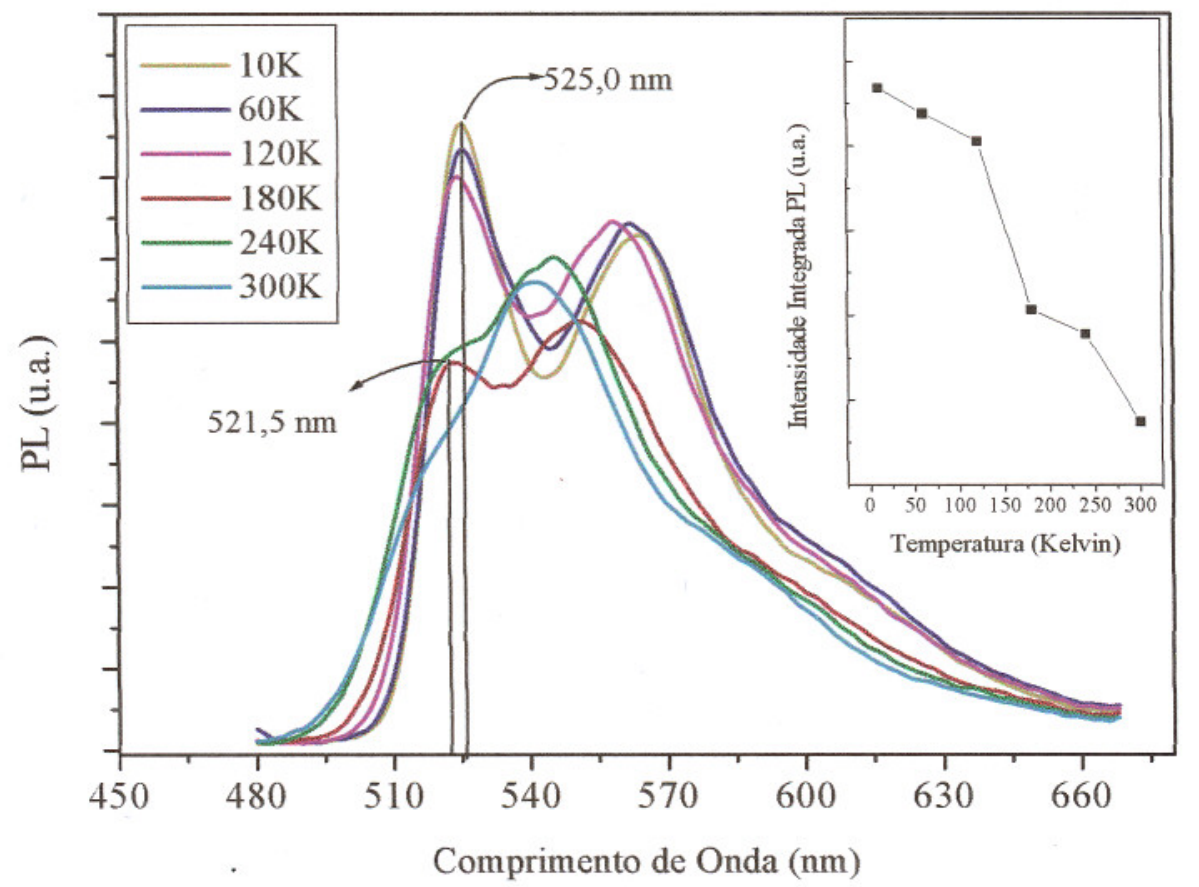

Figura 4.11: Espectros de fotoluminescência para comprimento de excitação de $442 \mathrm{~nm}$ em função da temperatura para o filme Cast-PPV estirado. As setas indicam o pico de PL para as temperaturas de $10 \mathrm{~K}$ e $180 \mathrm{~K}$ e os respectivos comprimentos de onda. Em detalhe a dependencia da intensidade integrada da PL do filme Casting de PPV 2 vezes estirado em função da temperatura.

A dependência dos espectros de fotoluminescência em função da temperatura (de 10 a $180 \mathrm{~K}$ ) mostrou que houve uma variação da forma de linha espectral relacionada à progressão vibracional e um deslocamento do $1^{\circ}$ pico (de $525 \mathrm{~nm}$ para $521 \mathrm{~nm}$ ) e do $2^{\circ}$ 
pico (de $563 \mathrm{~nm}$ para $552 \mathrm{~nm}$ ) para altas energias. A intensidade integrada da PL diminuiu com a temperatura, como mostra o gráfico em detalhe na Figura 4.11.

Observando os espectros de fotoluminescência polarizada a $60 \mathrm{~K}$, notou-se algumas variações na forma da linha espectral relacionada com a mudança de acoplamento elétron-fônon nas diferentes configurações de polarização, ver os espectro das configurações $\mathrm{P}_{1}=(/ /)$ e $\mathrm{P}_{2}=(/ /)$ e $\mathrm{P}_{1}=(\perp)$ e $\mathrm{P}_{2}=(\perp)$ do gráfico da Figura 4.12. Para explicar melhor este efeito basta observar as configurações de polarização. $\mathrm{Na} 1^{\circ}$ configuração de polarização, a qual apresenta direção da polarização da luz de excitação paralela ao estiramento, foram excitados principalmente os segmentos conjugados que estavam orientados na direção do estiramento. Como resultado, o espectro de fotoluminescência obtido se refere principalmente a esses segmentos. Na última configuração de polarização, excitaram-se os segmentos conjugados posicionados perpendicularmente à direção de estiramento, o que reduziu consideravelmente a intensidade dos picos da PL e a relação da intensidade entre os picos de zero - fônon $(524 \mathrm{~nm})$ e o $2^{\circ}$ pico $(560 \mathrm{~nm})$.

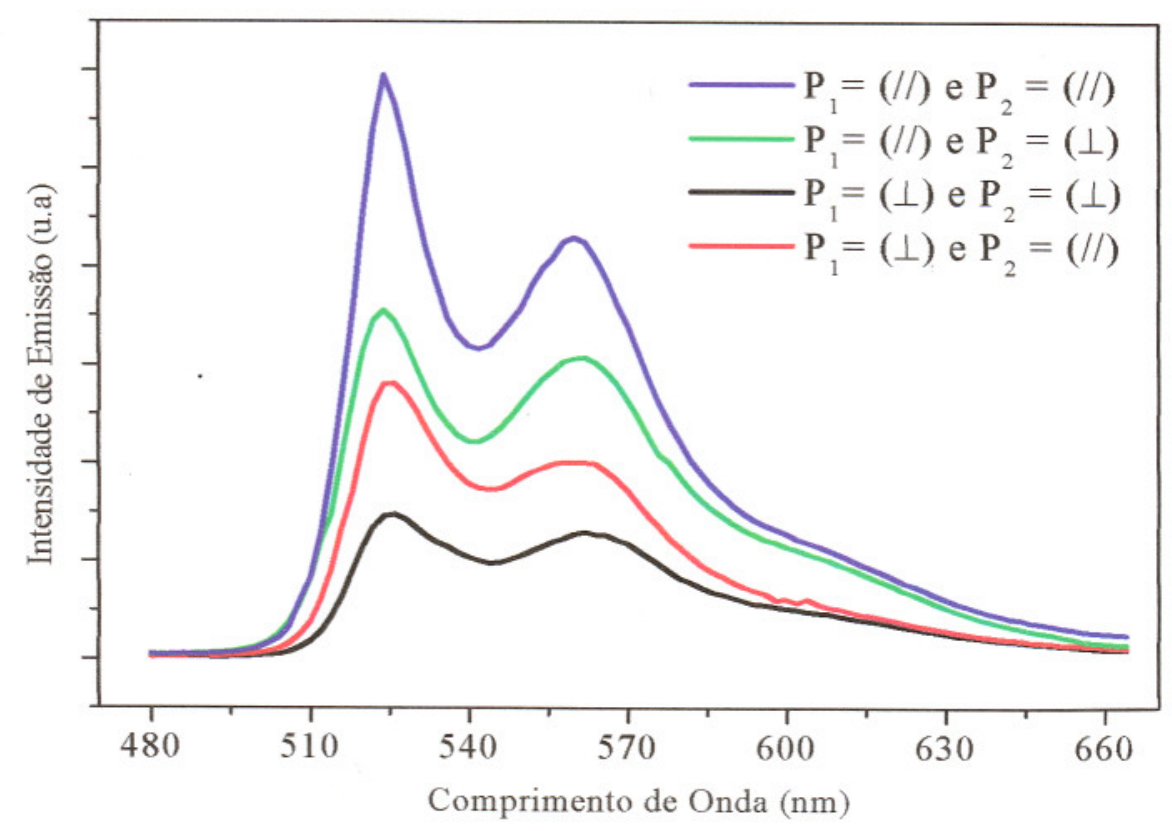

Figura 4.12: Espectro da fotoluminescência polarizada para o filme Cast-PPV Estirado à temperatura de $60 \mathrm{~K}$ para diferentes configurações da polarização da luz de excitação $P_{1}$ $\left(\lambda_{e x}=442 \mathrm{~nm}\right)$ e de emissão $P_{2}$. 
Deste modo, supõe-se que ao estirar o filme, além de torná-lo anisotrópico, os segmentos das moléculas com grau de conjugação maior ficam orientadas paralelamente à direção do estiramento, ou seja, ao estirar o filme as moléculas se alinham e as torções e enovelamentos são reduzidos e o número de segmentos conjugados aumenta. Orientados na direção perpendicular ao estiramento, ficariam então, os segmentos com menores graus de conjugações, que contribuem menos para o espectro de emissão. $O$ valor da razão de intensidade medida entre a configuração $\left(P_{1}=(/ /)\right.$ e $\left.P_{2}=(/ /)\right)$ e a $\left(P_{1}=\right.$ $(/ /)$ e $\left.\mathrm{P}_{2}=(\perp)\right)$ no pico de zero-fônon $(524 \mathrm{~nm})$ foi de 1,9 para o filme Cast-PPV Estirado. A intensidade da luz emitida pelo filme, $\mathrm{I}_{/}$, medida com o polarizador $\mathrm{P}_{2}$ paralelo à direção de estiramento da amostra e a componente da intensidade perpendicular, $\mathrm{I}_{\perp}$, medida com o polarizador $\mathrm{P}_{2}$ perpendicular à direção de estiramento, possibilitou o cálculo do valor da anisotropia de emissão $r=\left(I_{V}-I_{H}\right) /\left(I_{V}+2 I_{H}\right)=0,24$, medido no pico de zero-fônon, resultado bem superior aos obtidos com os filmes de PPV obtidos por Casting $(r=0,099)$ e por Spin-Coating $(r=0,18)$.

Utilizando a montagem experimental ilustrada no capítulo 3, item 3.2.2, no qual incide-se na amostra uma luz laser de excitação $\left(\lambda_{\text {ex }}=442 \mathrm{~nm}\right)$ com duas direções de polarização da luz, uma paralela $P_{1}(/ /)$ e outra perpendicular $P_{1}(\perp)$ à direção de estiramento da amostra e para cada direção da polarização da luz de excitação variou-se o ângulo do analisador $\left(\mathrm{P}_{2}\right)$ de $0^{\circ}$ a $360^{\circ}$ em intervalos de $10^{\circ}$. A Figura 4.13 mostra o gráfico da intensidade de emissão normalizada em função do ângulo do analisador para as duas direções de polarização da luz incidente. 


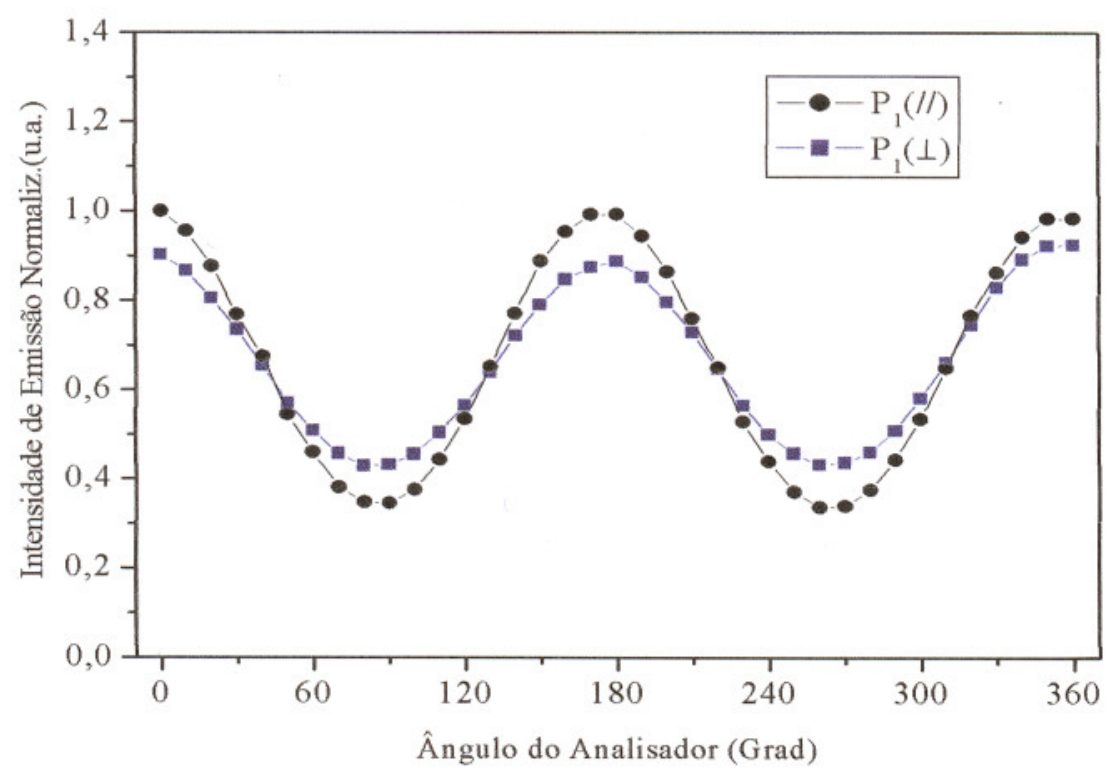

Figura 4.13: Medida da polarização da luz emitida pelo filme Cast-PPV Estirado. $O$ Gráfico mostra a intensidade da luz emitida normalizada em função do ângulo do analisador $P_{2}$ num intervalo $0^{\circ}$ a $360^{\circ}$, para as duas direções da polarização da luz de excitação, $P_{1}$ (//) paralelo e $P_{2}(\perp)$ perpendicular à direção de estiramento.

Através da medida de polarização da luz emitida pelo filme Cast-PPV Estirađâo (Figura 4.13), notou-se uma grande variação da intensidade de emissão em função do ângulo do analisador para ambas as direções de polarização da luz de excitação. Na primeira configuração (com a polarização da luz incidente paralela à direção do estiramento), a polarização da luz emitida foi linear na direção dos segmentos com alto grau de conjugação, com máximos de intensidade em $0^{\circ}, 180^{\circ}$ e $360^{\circ}$, mostrando ser um filme altamente anisotrópico. Na segunda configuração, porém (com a polarização da luz incidente perpendicular à direção do estiramento), a luz emitida apresentou direção de polarização paralela ao estiramento e perpendicular à direção da polarização da luz incidente, apresentando máximos de intensidade em $0^{\circ}, 180^{\circ}$ e $360^{\circ}$. A polarização da luz emitida pelo filme assumiu direção perpendicular à da polarização da luz incidente, 
estiramento) o filme apresentou polarização da luz emitida na direção do estiramento, onde havia uma probabilidade maior de encontrar segmentos com alto grau de conjugação. Para obter uma explicação razoável para tal efeito foi necessário relacionar o mecanismo de transferência de energia que provavelmente ocorreu entre as moléculas (doadoras e receptoras) com a morfologia do filme, e esta discussão se encontra em detalhe no item 4.2 .

\subsection{4- PROPRIEDADES ÓPTICAS DE FILMES DE LB - PPV.}

Neste trabalho, filmes de PPV foram preparados pela técnica Langmuir-Blodgett (LB) utilizando o contra-íon DBS (ver item 3.3.3). Esta técnica tem a propriedade de produzir filmes moleculares finos e ordenados. $O$ espectro de absorção para um filme LB-PPV de 28 monocamadas apresenta intensidades de absorção distintas para luz polarizada linearmente na direção paralela $\left(A_{/ /}\right)$e perpendicular $\left(A_{\perp}\right)$ à direção de imersão (dipping), como pode ser verificado na Figura 4.14. Para esta amostra em especial, a razão anisotrópica $\delta=A_{/ /} / A_{\perp}$ entre os máximos da absorção foi de 3,6 valores muito próximos da literatura [14]. Estes máximos se localizam em $455 \mathrm{~nm}$ e $432 \mathrm{~nm}$ para a orientação paralela e perpendicular, respectivamente. 
$O$ valor do parâmetro de ordem molecular no plano do filme $\beta=\left(\mathrm{A}_{/ /-}\right.$ $\left.A_{\perp}\right) /\left(A_{/ /}+A_{\perp}\right)$ próximo ao canto da banda de absorção resultou em $\beta=0,6$. Este valor de $\beta$ é comparado àquele encontrado tipicamente em filmes LB orientados e cristais líquidos [42].

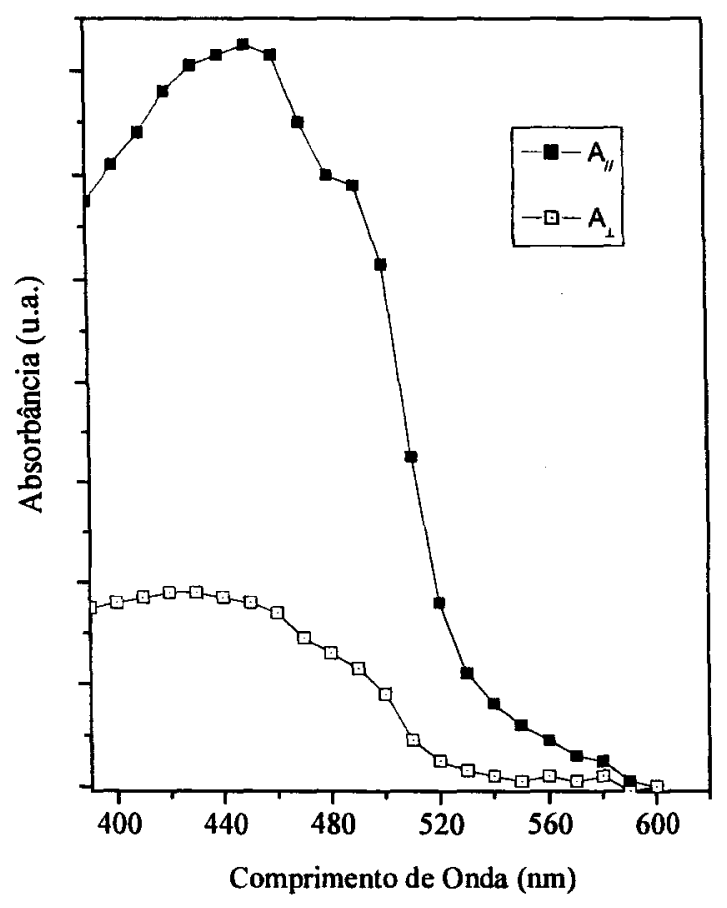

Figura 4.14: Medidas de absorbância polarizada à temperatura ambiente para o filme LB-PPV. $A_{/ /}$e $A_{\perp}$ são as absorções nas direções de polarização da luz incidente paralelamente $e$ perpendicularmente à direção de imersão do filme, respectivamente.

A medida de fotoluminescência (PL) em diferentes temperaturas (10 a $300 \mathrm{~K}$ ) para esta amostra está ilustrada na Figura 4.15, onde se encontra em detalhe o gráfico de intensidade integrada da PL em função da temperatura. 


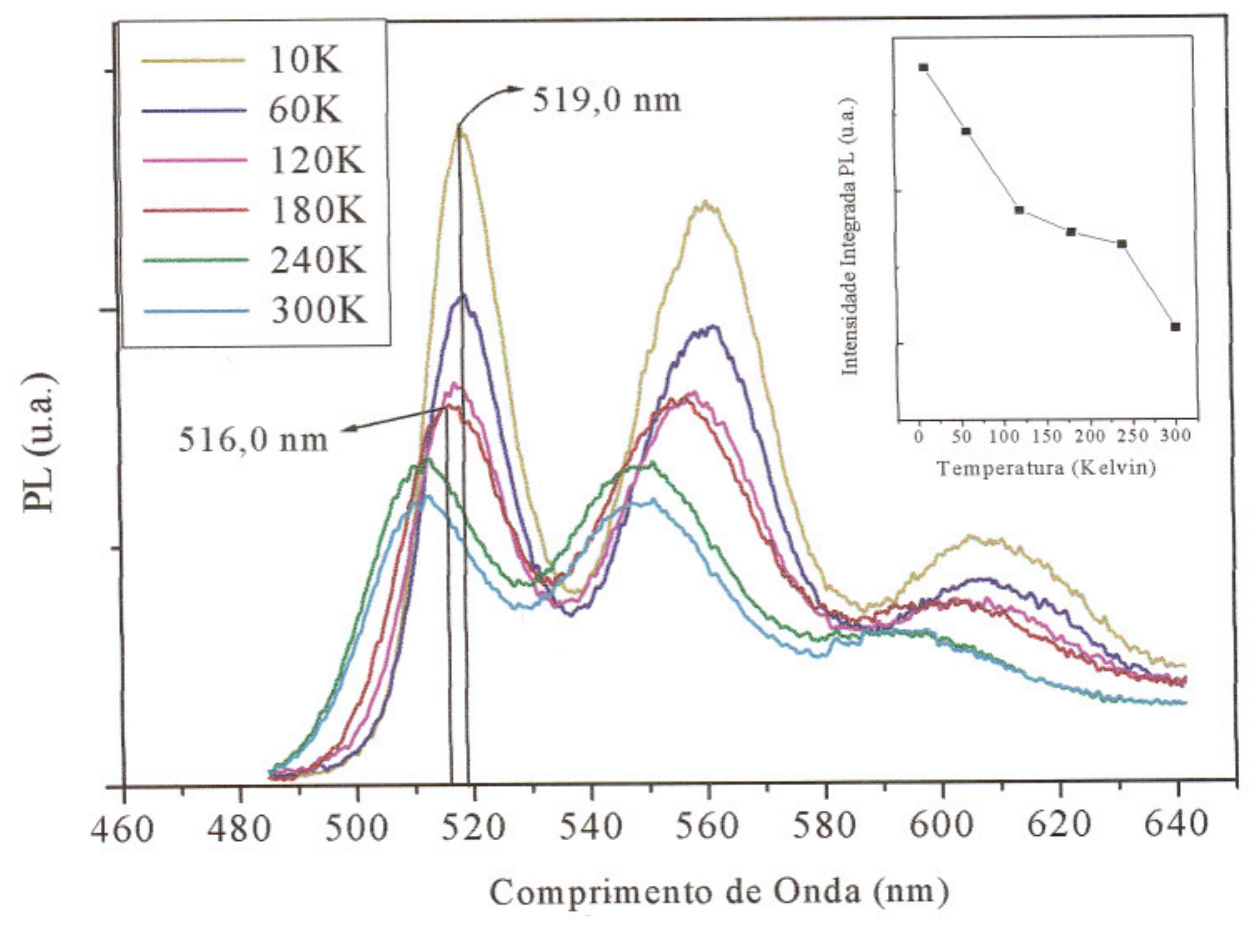

Figura 4.15: Espectros de fotoluminescência para comprimento de excitação de $442 \mathrm{~nm}$ em função da temperatura para filme $L B-P P V$. As setas indicam o pico de PL para as temperaturas de $10 \mathrm{~K}$ e $180 \mathrm{~K}$ e os respectivos comprimentos de onda. Em detalhe a dependência da intensidade integrada da PL em função da temperatura.

$\mathrm{Na}$ Figura 4.15. A forma de linha da PL apresenta as mesmas características relativas às intensidades dos picos na região das réplicas de fônon no intervalo de $10 \mathrm{a}$ $180 \mathrm{~K}$, ou seja, a intensidade das estruturas vibracionais aumenta com a temperatura. Isto indica que o acoplamento elétron-fônon aumenta com a desordem térmica, deslocando os picos para menores comprimentos de onda. A intensidade integrada da PL diminuiu com o aumento da temperatura, como constatado anteriormente.

A medida de fotoluminescência polarizada realizada excepcionalmente a $180 \mathrm{~K}$ para diferentes configurações da polarização da luz de excitação $P_{1}$ mostrou que o filme 
LB-PPV apresentou variações na intensidade e na forma da linha espectral relacionada com a mudança de acoplamento elétron-fônon, como mostra o gráfico da Figura 4.16.

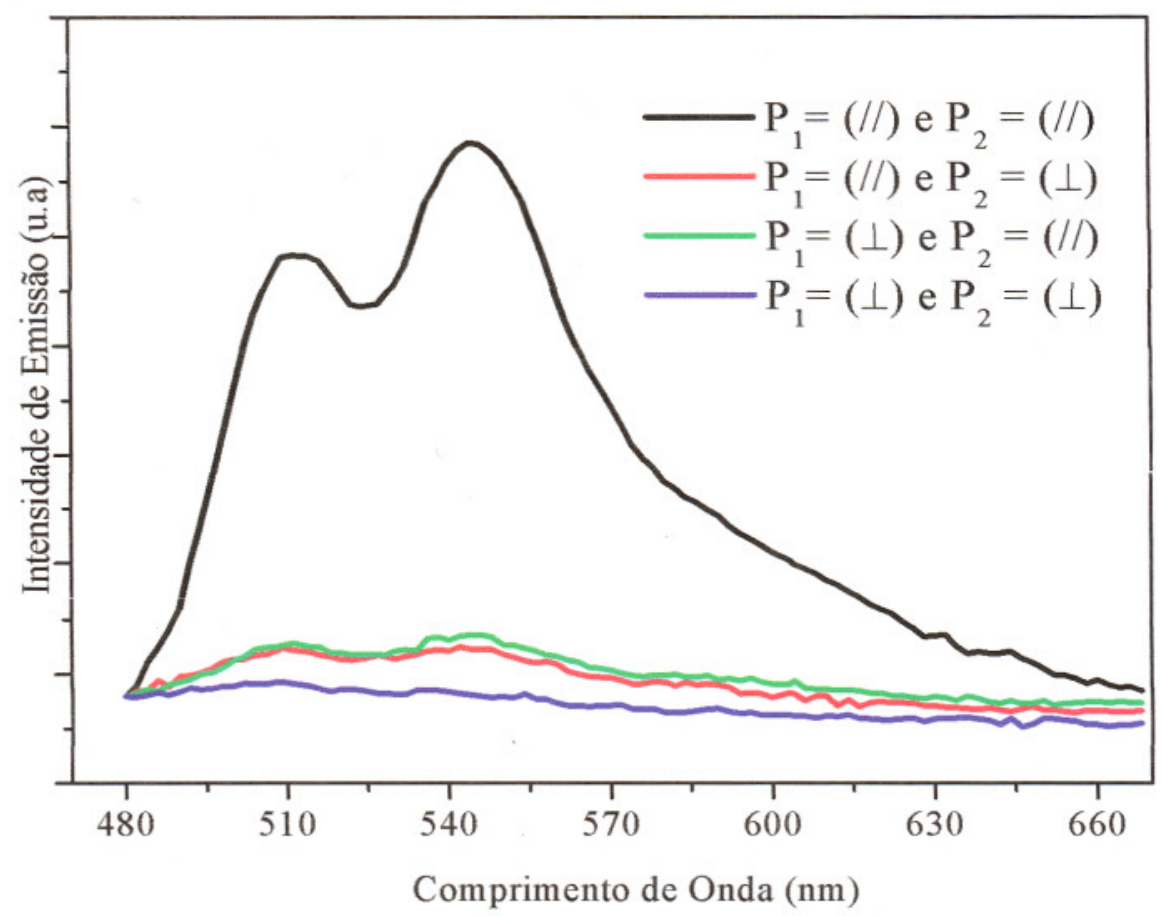

Figura 4.16: Espectro da fotoluminescência polarizada para o filme $L B-P P V$ à temperatura de $180 \mathrm{~K}$, para diferentes configurações da polarização da luz de excitação $P_{1}\left(\lambda_{e x}=442 \mathrm{~nm}\right)$ e de emissão $P_{2}$.

A configuração $\mathrm{P}_{1}=(/ /)$ e $\mathrm{P}_{2}=(/ /)$, com a direção da polarização da luz de excitação paralela à direção de imersão do filme, apresentou a maior intensidade de PL, enquanto as configurações $\mathrm{P}_{1}=(/ /)$ e $\mathrm{P}_{2}=(\perp), \mathrm{P}_{1}=(\perp)$ e $\mathrm{P}_{2}=(/ /)$ e $\mathrm{P}_{1}=(\perp)$ e $\mathrm{P}_{2}=(\perp)$ apresentaram uma intensidade 3 vezes menor. Os resultados da medida do espectro polarizado mostraram que o filme possui os segmentos das moléculas (com maiores graus de conjugação) ordenados na direção de imersão. Perpendiculares a esta direção estão os segmentos com menores graus de conjugação, como se pode observar na variação da forma da linha espectral devido á mudanças de acoplamento elétron-fônon. 
$\mathrm{O}$ valor da razão de intensidade medida entre a configuração $\left(\mathrm{P}_{1}=(/ /)\right.$ e $\left.\mathrm{P}_{2}=(/ /)\right)$ e a $\left(\mathrm{P}_{1}\right.$ $=(/ /)$ e $\left.\mathrm{P}_{2}=(\perp)\right)$ no pico de zero-fônon $(510 \mathrm{~nm})$ foi de 3,7 bem próximo para o valor encontrado na literatura [42] para o filme de PPV obtido pela técnica LB. O valor da anisotropia de emissão $r=\left(\mathrm{I}_{\mathrm{V}}-\mathrm{I}_{\mathrm{H}}\right) /\left(\mathrm{I}_{\mathrm{V}}+2 \mathrm{I}_{\mathrm{H}}\right)$ foi de 0,5 quando medido no pico de zero-fônon, bem maior que encontrado para o filme Cast-PPV Estirado $(r=0,24)$, para o filme Cast-PPV $(r=0,099)$ e para o filme Spin-PPV $(r=0,18)$.

$\mathrm{O}$ gráfico da intensidade de emissão normalizada em função do ângulo do analisador (Grau) num intervalo de $0^{\circ}$ a $360^{\circ}$ em relação à direção de imersão da amostra para as duas direções de polarização da luz incidente $\left(\lambda_{\mathrm{ex}}=442 \mathrm{~nm}\right)$, está mostrado pela Figura 4.17.

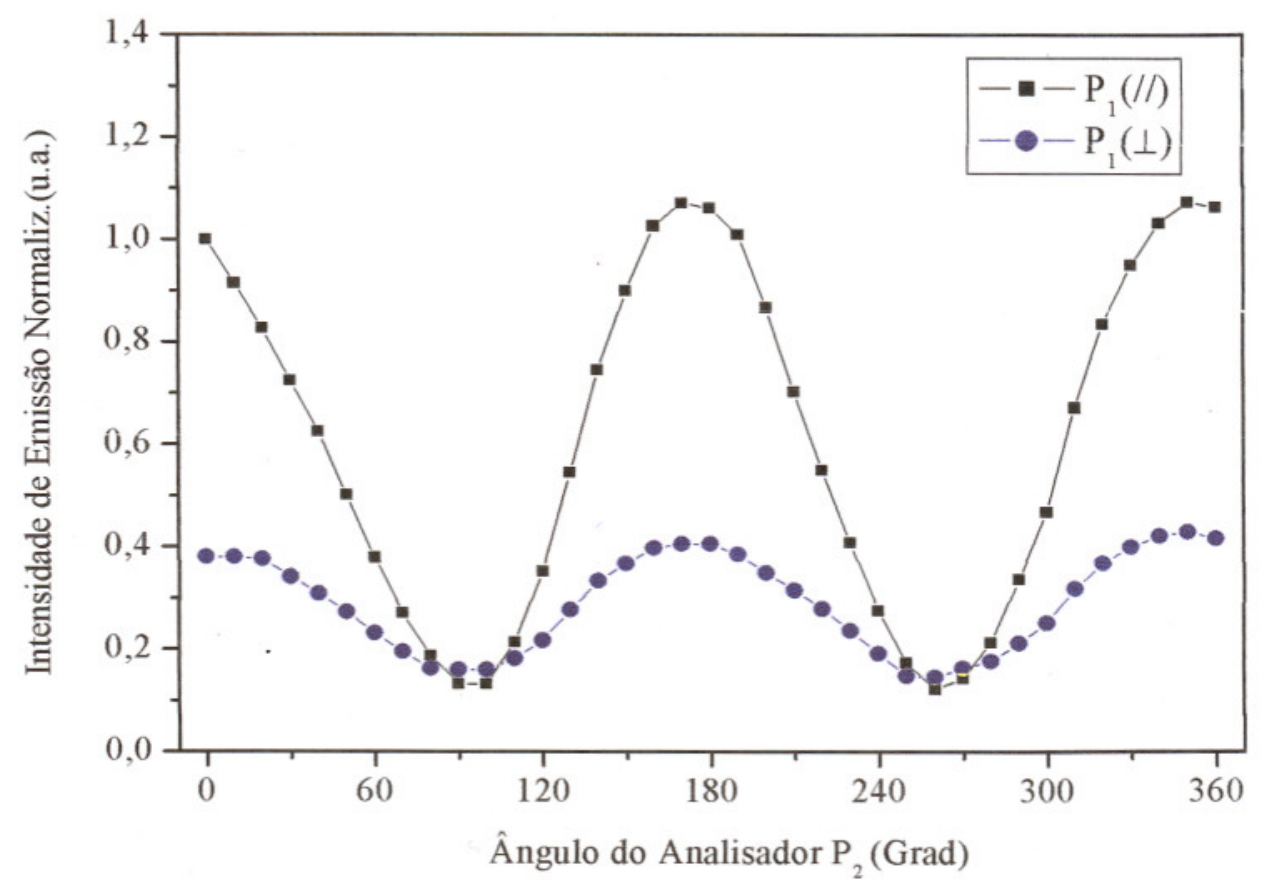

Figura 4.17: Medida da polarização da luz emitida pelo LB-PPV. O Gráfico acima mostra a intensidade da luz emitida normalizada em função do ângulo do analisador $P_{2}$ num intervalo $0^{\circ}$ a $360^{\circ}$, para as duas direções da polarização da luz de excitação, $P_{1}$ (//) paralelo e $P_{2}(\perp)$ perpendicular à direção de imersão da amostra. 
analisador para ambas as direções de polarização da luz de excitação. Na primeira configuração (com a polarização da luz incidente paralela à direção de imersão do filme), excitaram-se principalmente os segmentos conjugados que estavam orientados nesta direção e a polarização da luz emitida foi linear na direção dos segmentos, com máximos de intensidade em $0^{\circ}, 180^{\circ}$ e $360^{\circ}$, mostrando ser um filme altamente anisotrópico. $\mathrm{Na}$ segunda configuração (com a polarização da luz incidente perpendicular à direção do estiramento), excitaram-se os segmentos conjugados orientados perpendicularmente à direção de imersão e a luz emitida, no entanto, apresentou direção de polarização paralela à direção de imersão e conseqüientemente, perpendicular à direção da polarização da luz incidente, apresentando máximos de intensidade também em $0^{\circ}, 180^{\circ}$ e $360^{\circ}$, como mostra o gráfico da Figura 4.17. Uma possível explicação para a mudança da direção de polarização entre a luz incidente e a emitida se encontra no item 4.2 .

\subsection{5- PROPRIEDADES ÓPTICAS DE FILMES DE SELF-ASSEMBLY (S.A) ESTIRADO.}

As propriedades dos filmes de PPV obtidos pela técnica de Self-Assembly (S.A) e estirado 2 vezes do seu tamanho original foram estudadas com mais detalhes através de medidas de absorção polarizada à temperatura ambiente, para verificar se apresenta alguma anisotropia de absorção na direção paralela $\left(\mathrm{A}_{/ /}\right)$e perpendicular $\left(\mathrm{A}_{\perp}\right)$ à direção do estiramento. $\mathrm{O}$ resultado da medida está representado pelo gráfico da Figura 4.18. 


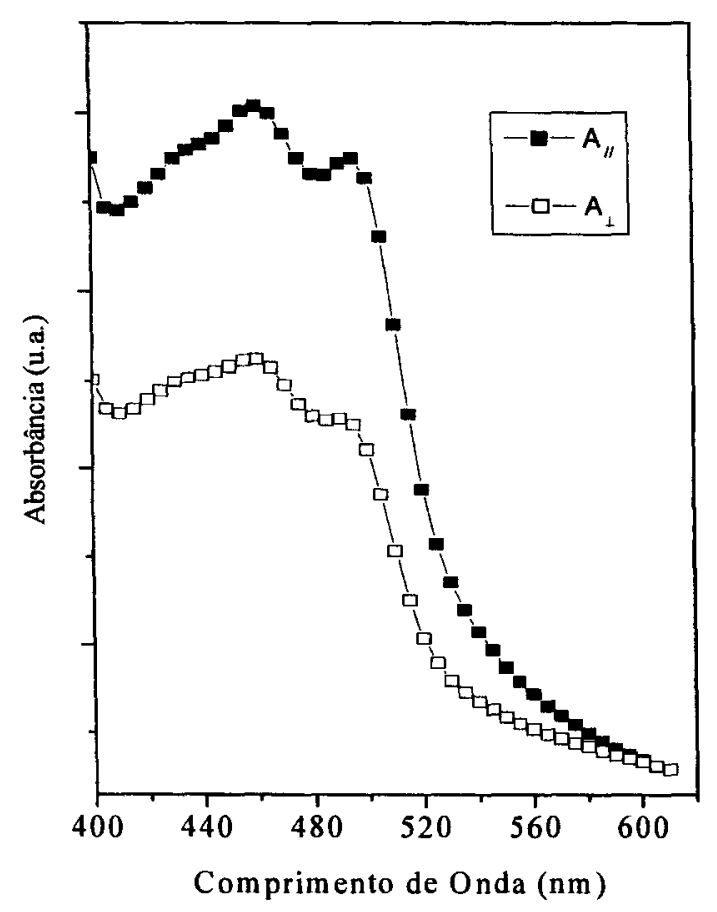

Figura 4.18: Medidas de absorbância polarizada à temperatura ambiente para o filme S.A-PPV Estirado. $A_{/ /}$e $A_{\perp}$ são as absorções nas direções de polarização da luz incidente paralelamente e perpendicularmente à direção de estiramento do filme, respectivamente.

De acordo com o gráfico da Figura 4.18, o filme apresentou uma forte anisotropia de absorção na direção do estiramento. $O$ grau de orientação caracterizado pela razão anisotrópica $(\delta)$ foi de 1,5 entre os máximos de absorção e valor do parâmetro de ordem molecular no plano do filme $(\beta)$ foi de 0,19 .

A medida de fotoluminescência (PL) em diferentes temperaturas (10 a $300 \mathrm{~K}$ ) está ilustrada na Figura 4.19, a figura também mostra o gráfico de intensidade integrada da PL em função da temperatura. 


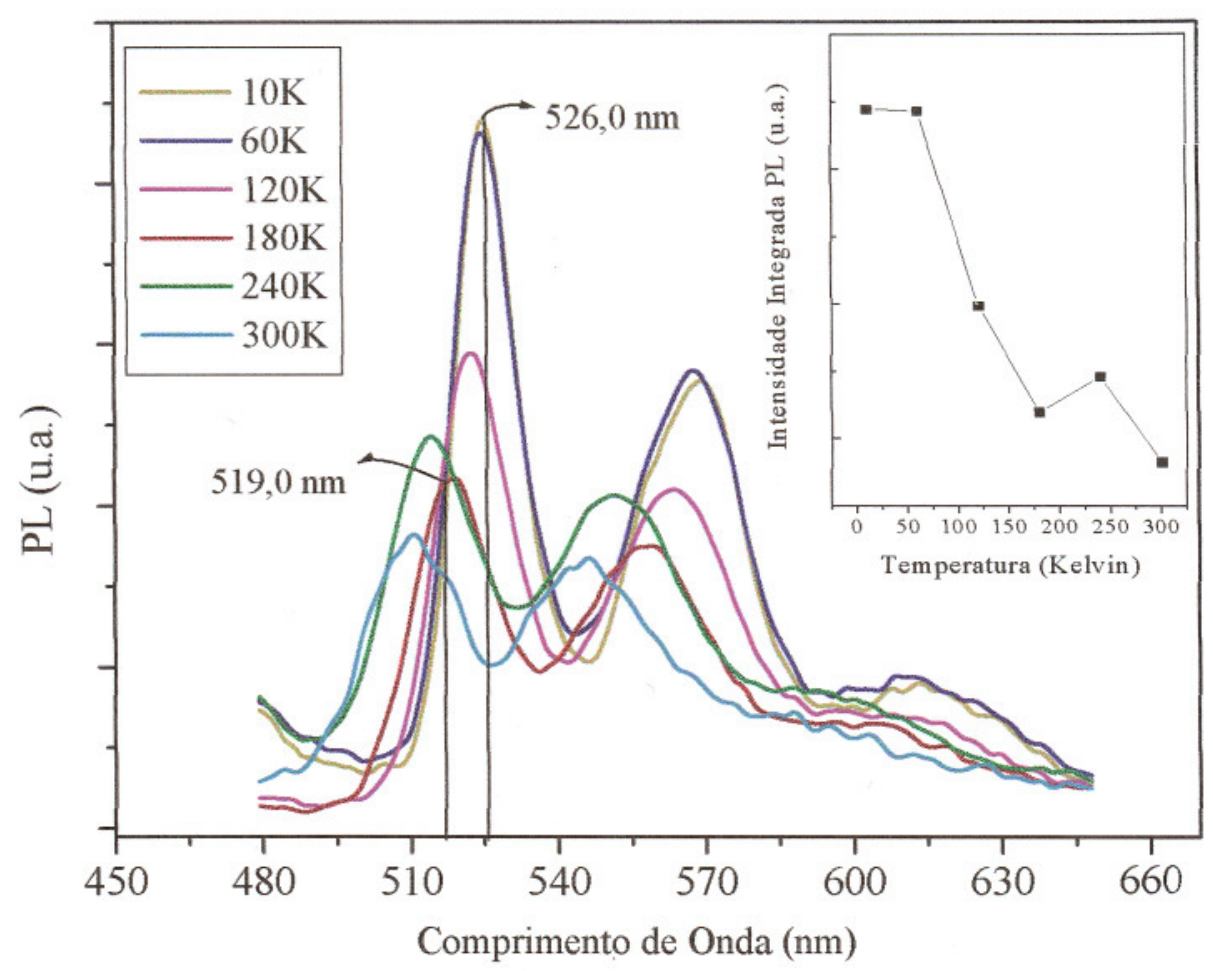

Figura 4.19: Espectros de fotoluminescência em função da temperatura para filme S.A-PPV. Estirado. As setas indicam o pico de PL para as temperaturas de $10 \mathrm{~K}$ e $180 \mathrm{~K}$ e os respectivos comprimentos de onda. Em detalhe a dependência da intensidade integrada da PL em função da temperatura.

Observando o gráfico da Figura 4.19, nota-se que houve uma variação da forma de linha espectral relacionada à progressão vibracional e um deslocamento do $1^{\circ}$ pico (de zero-fônon) de 526,0 nm para 519,0 nm para altas energias. Ocorreu uma redução da intensidade da PL integrada com o aumento da temperatura como mostra o gráfico em detalhe na Figura 4.19.

A medida de fotoluminescência polarizada à $60 \mathrm{~K}$ para diferentes configurações da polarização da luz de excitação $P_{1}$ para o filme de S.A-PPV Estirado está representada pelo gráfico da Figura 4.20. 


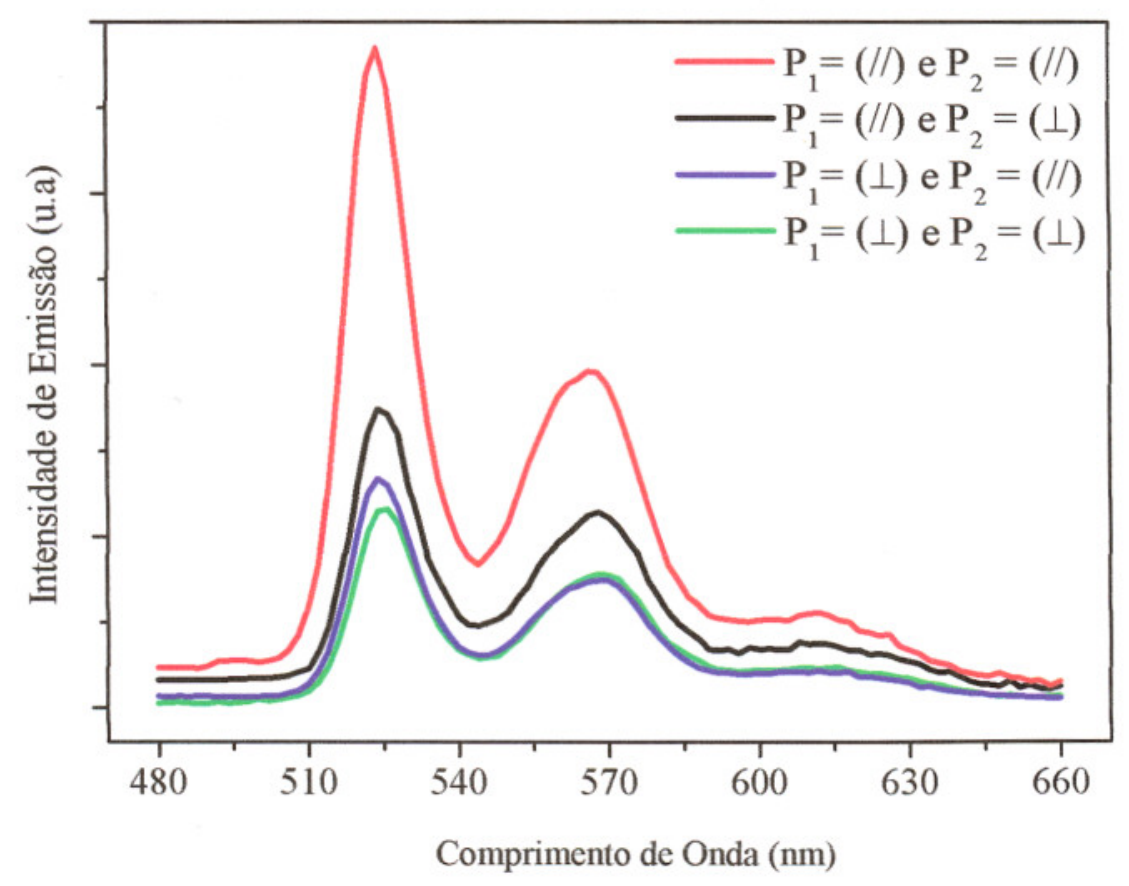

Figüräa 4.20: Espectro da fotoluminescência polarizada para o filme S.A-PPV Estirado à temperatura de $60 \mathrm{~K}$, para diferentes configurações da polarização da luz de excitação $P_{1}$ $\left(\lambda_{e x}=442 \mathrm{~nm}\right)$ e de emissão $P_{2}$.

Observando os espectros de fotoluminescência polarizada, notou-se novamente algumas variações na forma da linha espectral relacionada com a mudança de acoplamento elétron-fônon, nas diferentes configurações de polarização. Tal resultado sugere que ao estirar o filme eliminam-se os enovelamentos e as torções, fazendo com que os segmentos orientados na direção do estiramento apresentem maior grau de conjugação. $\mathrm{O}$ valor da razão de intensidade medida entre a configuração $\left(\mathrm{P}_{1}=(/ /)\right.$ e $\mathrm{P}_{2}=$ $(/ /))$ e a $\left(\mathrm{P}_{1}=(/ /)\right.$ e $\left.\mathrm{P}_{2}=(\perp)\right)$ foi de 2,2 no pico de zero-fônon $(524,4 \mathrm{~nm})$, valor maior que o da razão de estiramento do filme, indicando que o filme apresentou alto grau de ordenamento molecular. $\mathrm{O}$ valor da anisotropia de emissão foi de $r=0,28$, mostrando que o filme é bastante anisotrópico. O valor encontrado para o filme LB-PPV foi de $r=$ 0,5, para o filme Cast-PPV Estirado foi de $r=0,24$, para o filme Cast-PPV foi de $r=$ 0,099 e para o filme Spin-PPV de $r=0,18$. 
Para realizar as medidas do estudo da polarização da luz emitida por esses filmes utilizou a montagem experimental ilustrada no capítulo 3, item 3.2.3. A Figura 4.21 mostra o gráfico da intensidade de emissão normalizada (u.a.) como função do ângulo do analisador para as duas direções de polarização da luz incidente, paralela $\mathrm{P}_{1}(/ /)$ e perpendicular $\mathrm{P}_{1}(\perp)$ à direção de estiramento.

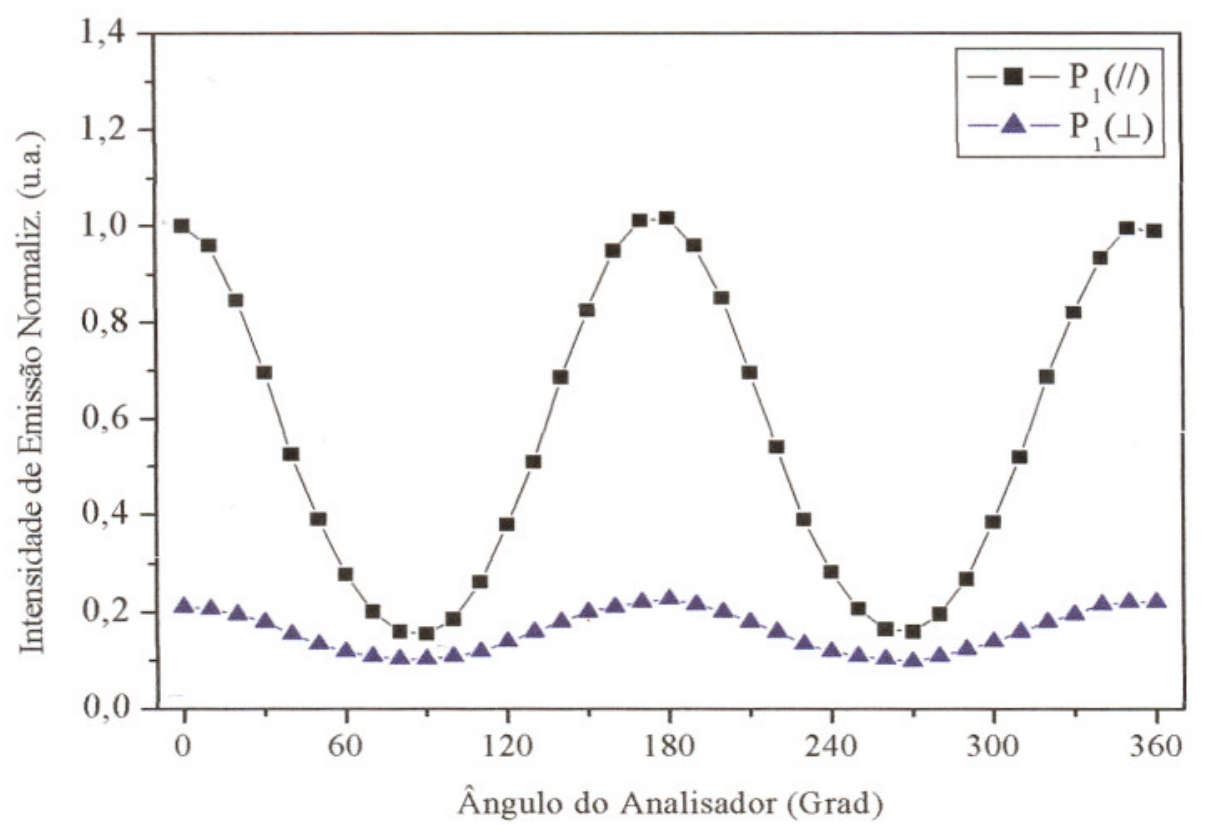

Figura 4.21: Medida da polarização da luz emitida pelo filme S.A-PPV Estirado. O Gráfico acima mostra a intensidade da luz emitida em função do ângulo do analisador $P_{2}$ num intervalo $0^{\circ}$ a $360^{\circ}$, para as duas direções da polarização da luz de excitação, $P_{1}$ (I/) paralelo e $P_{2}(\perp)$ perpendicular à direção de estiramento da amostra.

Na primeira configuração (com a polarização da luz incidente paralela à direção do estiramento do filme), onde se excitaram principalmente os segmentos conjugados orientados a esta direção, a polarização da luz emitida foi linear na direção do estiramento com máximos de intensidade em $0^{\circ}, 180^{\circ}$ e $360^{\circ}$ como mostra o gráfico da Figura 4.9. Na segunda configuração (com a polarização da luz incidente perpendicular à direção do estiramento), a luz emitida com menor intensidade apresentou direção de polarização paralela ao estiramento, ou seja, perpendicular à direção da polarização da 
luz incidente, apresentando máximos de intensidade também em $0^{\circ}, 180^{\circ}$ e $360^{\circ}$. Neste caso, a polarização da luz emitida pelo filme assumiu direção perpendicular à da polarização da luz incidente, não havendo conservação da polarização incidente. Independente da direção de polarização da luz incidente (paralela ou perpendicular à direção do estiramento) o filme emitiu luz polarizada na direção do estiramento. Relacionando o mecanismo de transferência entre moléculas com o ordenamento molecular do filme, obteve-se (em detalhe no item 4.2) uma explicação razoável para tal efeito.

\section{2- MECANISMO DE TRANSFERÊNCIA DE ENERGIA TIPO FÖRSTER NOS} FILMES DE PPV:

Apesar do grande esforço para o entendimento das propriedades de luminescência dos polímeros emissores de luz, os processos fotofísicos envolvendo transferência de energia entre moléculas conjugadas são pouco entendidos devido à grande variedade morfológica assumidas por estes materiais [62, 63-65]. Entretanto, a teoria de Förster (radiação dipolo-dipolo), proposta há meio século atrás, parece explicar coerentemente os resultados obtidos para os diferentes filmes de PPV investigados neste trabalho, permitindo ainda correlacionar suas propriedades ópticas com o ordenamento molecular. Os itens seguintes mostram como a teoria de Förster pode ser utilizada como hipótese para explicar os resultados experimentais dos filmes de PPV correlacionados com a anisotropia óptica do filme. 


\subsection{1- MECANISMO DE TRANSFERÊNCIA DE ENERGIA PARA FILMES DE PPV OBTIDO PELO MÉTODO CASTING:}

Analisando o gráfico da Figura 4.5, o qual mostra a intensidade da luz emitida normalizada em função do ângulo do analisador para a amostra Cast-PPV, observou-se que para a luz de excitação com polarização na direção paralela ao eixo vertical da amostra, a luz emitida pelo filme apresentou polarização linear na direção vertical da amostra. Os máximos de intensidade ocorreram quando o analisador estava posicionado em $0^{\circ}, 180^{\circ}$ e $360^{\circ}$, justamente na direção de polarização da luz de excitação, conservando a direção de polarização entre a luz incidente e a luz emitida. $O$ mesmo efeito foi observado para a polarização da luz de excitação perpendicular ao eixo vertical da amostra, no qual os máximos de intensidade ocorrerem nos ângulos $90^{\circ}$ e $270^{\circ}$ (direção de polarização da luz incidente), caracterizando a emissão de luz linearmente polarizada na direção perpendicular ao eixo vertical da amostra. Estes efeitos podem ser explicados considerando a hipótese de ter ocorrido transferência de energia tipo Förster entre as moléculas com baixo grau de conjugação (doadoras), posicionadas no filme de modo aleatório e paralelo à polarização da luz de excitação, e as moléculas de alto grau de conjugação (receptoras), também desorientadas em relação à polarização da luz de excitação. Como os segmentos de alto grau de conjugação são os principais responsáveis pela emissão [37] e se encontram orientados aleatoriamente, a polarização da luz emitida deveria assumir qualquer direção quando analisada num intervalo de $0^{\circ}$ a $360^{\circ}$. Entretanto, observou-se variação na intensidade da luz emitida pelo filme em função do ângulo do analisador, com máximo de intensidade na direção da polarização da luz de excitação. Isto deve ter ocorrido, pois a energia foi transferida, preferencialmente, entre as moléculas que possuíam as mesmas direções (ou próximas) orientadas aleatoriamente no filme na direção da polarização da luz de excitação, conservando a direção da polarização entre a luz incidente e a emitida. Mas como a probabilidade de encontrar moléculas orientadas paralelamente umas as outras num filme desordenado é bastante baixa, a intensidade da luz emitida pouco variou com o ângulo do analisador. 


\subsection{2- MECANISMO DE TRANSFERÊNCIA DE ENERGIA PARA FILMES DE PPV OBTIDOS PELA TÉCNICA SPIN-COATING:}

De acordo com os resultados da medida da polarização da luz emitida em função do ângulo do analisador obtido para o filme Spin-PPV (Figura 4.13), observou-se que a da polarização da luz emitida apresentou a mesma direção da polarização da luz incidente. Quando a polarização da luz incidente estava paralela ou perpendicularmente à direção do eixo vertical da amostra, a luz emitida apresentou polarização na direção paralela (máximos de intensidade em $0^{\circ}, 180^{\circ}$ e $360^{\circ}$ ) e perpendicular (máximos em $90^{\circ}$ e $270^{\circ}$ ) ao eixo vertical da amostra, respectivamente. Como hipótese para explicar este comportamento utilizou-se o mecanismo de transferência via Förster. Como no processo de obtenção do filme por esta técnica a homogeneidade é obtida através da rotação do substrato, os segmentos conjugados assumem orientações preferenciais na direção radial, no plano do filme [66] e conseqüentemente, estão paralelas às duas direções de $P_{1}$. Assim, a energia absorvida por uma molécula orientada paralela à polarização da luz de excitação foi transferida para outra molécula de maior segmento (receptora), ambas orientadas na direção paralela à polarização da luz de excitação, de modo a conservar a direção da polarização entre a luz incidente e a luz emitida, como se pode observar no gráfico da Figura 4.13.

\subsection{3- MECANISMO DE TRANSFERÊNCIA DE ENERGIA PARA FILMES DE PPV ESTIRADOS OBTIDOS PELO MÉTODO CASTING:}

De acordo com os resultados obtidos da medida da polarização da luz emitida pelo filme Cast-PPV Estirado (Figura 4.9), nota-se que independente da direção de polarização da luz incidente (paralela ou perpendicular à direção do estiramento) a luz 
emitida é polarizada na direção do estiramento do filme. Relacionando esses resultados com o mecanismo de transporte entre moléculas, encontram-se algumas hipóteses que explicam este efeito. $\mathrm{Na}$ primeira configuração $\mathrm{P}_{1}(/ /)$, a energia absorvida pelos segmentos (doadores) de graus de conjugação maiores, que se encontram orientadas paralelamente à direção do estiramento, foi transmitida para outra molécula (receptora), também com a mesma orientação que posteriormente emitiu luz nesta direção. $\mathrm{Na}$ segunda configuração $\mathrm{P}_{1}(\perp)$, onde a polarização da luz incidente era perpendicular à direção do estiramento, a energia absorvida pelos segmentos conjugados com orientação na direção perpendicular ao estiramento (com baixo grau de conjugação) foi transferida para os segmentos conjugados vizinhos até ser reabsorvida pelas moléculas de segmentos maiores, as quais se excitaram e posteriormente emitiram. Como no caso deste filme as moléculas de segmentos maiores estão em sua maioria orientados na direção do estiramento, a luz emitida se dá nesta direção. Como podem ser observados na Figura 4.9, os máximos de intensidade ocorrem em $0^{\circ}, 180^{\circ}$ e $360^{\circ}$ para ambas configurações de $\mathrm{P}_{1}$. Concluiu-se neste caso, que ao excitar segmentos conjugados menores orientados na direção da polarização da luz incidente, a energia é eficientemente transferida para cadeias de segmentos longos orientados na direção do estiramento $[37,42]$.

\subsection{4- MECANISMO DE TRANSFERÊNCIA DE ENERGIA PARA FILMES DE PPV OBTIDOS PELA TÉCNICA LANGMUIR-BLODGETT (LB):}

Os resultados da medida da polarização da luz emitida em função do ângulo do analisador para o filme LB-PPV mostraram que ao excitar a amostra com luz polarizada paralela à direção de imersão do filme $P_{1}(/ /)$, a luz emitida tem polarização também nesta direção, com máximos de intensidade em $0^{\circ}, 180^{\circ}$ e $360^{\circ}$, como mostra a Figura 4.17. Porém, este mesmo filme quando excitado com luz polarizada perpendicular à 
direção de imersão do filme $P_{1}(\perp)$, a luz emitida apresentou polarização na direção paralela à direção de imersão, com máximos de intensidade também em $0^{\circ}, 180^{\circ} \mathrm{e} 360^{\circ}$. Utilizando a teoria de Förster como hipótese para explicar os resultados obtidos, acredita-se que na primeira configuração $\mathrm{P}_{1}(/ /)$, a energia absorvida por uma molécula orientada na direção de imersão (dipping) foi transferida (sistema dipolo-dipolo) para outros segmentos conjugados de mesma orientações e com maiores graus de conjugação, que posteriormente emitiram luz polarizadas na direção de orientação. Na segunda configuração $\mathrm{P}_{1}(\perp)$, a energia absorvida pelos segmentos conjugados orientados na direção perpendicular à imersão do filme (com baixo grau de conjugação) foi transferida para os segmentos conjugados vizinhos com maiores segmentos de conjugação que, no caso deste filme, encontravam em sua maioria orientadas na direção de imersão do filme (lembrando que a energia é eficientemente transferida para cadeias de segmentos longos orientados na direção de imersão [42]). Assim, a luz emitida neste caso também se apresentou polarizada na direção de imersão do filme. Portanto, verificou-se que o filme LB-PPV quando excitado com luz polarizada paralela ou perpendicularmente à direção de imersão, a luz emitida apresentou polarização linearmente, sempre na direção de imersão.

\subsection{5- MECANISMO DE TRANSFERÊNCIA DE ENERGIA PARA FILMES DE PPV ESTIRADOS OBTIDOS PELA TÉCNICA DE SELF-ASSEMBLY (S.A):}

Considerando a hipótese de ter ocorrido transferência de energia tipo Förster entre os segmentos conjugados do filme S.A-PPV Estirado, observou-se que para a primeira configuração $\mathrm{P}_{1}(/ /)$, a energia absorvida pela molécula doadora que se encontra orientada na direção do estiramento foi transferida à molécula receptora, orientada na mesma direção como num sistema dipolo-dipolo. A luz emitida foi linear e na direção do estiramento, como se observa na Figura 4.21. Para a configuração $P_{1}(\perp)$, a energia absorvida pelos segmentos conjugados orientados na direção perpendicular ao estiramento (com baixo grau de conjugação) foi transmitida para os segmentos 
conjugados vizinhos até encontrar os que possuíssem maiores segmentos de conjugação que, neste caso, estavam orientados em sua grande maioria na direção do estiramento (perpendiculares aos segmentos conjugados que absorveram). A luz emitida apresentou polarização na direção do estiramento. Analisando o comportamento da polarização em filmes ordenados pode-se concluir que a luz emitida apresenta sempre polarização na direção do estiramento, independente da direção de polarização da luz incidente (seja ela paralela ou perpendicular à direção do estiramento).

\subsection{CÁLCULO DA DISTÂNCIA CRÍTICA DE FÖRSTER $\left(\mathbf{R}_{0}\right)$ :}

Neste item são apresentados os cálculos teóricos da distância crítica de Förster para cada filme de PPV obtidos por diferentes técnicas, com o objetivo de verificar se a hipótese utilizada para explicar os resultados obtidos nas medidas de polarização da luz emitida pelo fenômeno de transferência de energia é válida. Deve-se enfatizar que a transferência de energia pelo processo Förster somente é assegurada se a distância entre o doador e o receptor for de 10 a $100 \AA[13,63-64]$. De acordo com a Equação (2.19) descrita no capítulo 2, é possível calcular o raio de Förster para cada umas das amostras. A distância crítica de Förster $\left(R_{0}\right)$ pode ser escrita como [67]:

$$
R_{0}^{6}=8,82 \times 10^{-28}\left(Q_{D} \cdot k^{2} \cdot n^{-4}\right) \int \frac{f(\bar{v}) \varepsilon(\bar{v})}{\bar{v}^{4}} d \bar{v}
$$

onde $Q_{D}$ eficiência quântica de luminescência do doador, $n$ é o índice de refração do meio e $\bar{v}$ é o número de ondas expresso em $\left(\mathrm{cm}^{-1}\right)$. Substituindo os valores dos parâmetros, tem-se:

$$
R_{0}^{6}=2,75 \times 10^{-29} . J
$$


onde $J=\int \frac{f(\bar{v}) \varepsilon(\bar{v})}{\bar{v}^{4}} d \bar{v}$

A integral $J$ é calculada pela superposição do espectro da luminescência e do espectro da absorção em $\left(\mathrm{M}^{-1} \mathrm{~cm}^{3}\right)$ dos filmes, dados em números de onda $\left(\mathrm{cm}^{-1}\right)$ [63]. Os gráficos da superposição do espectro da luminescência e do espectro da absorção para cada filme de PPV encontram-se no Anexo. A Tabela 1 ilustra os valores da integral obtidos e a distância crítica de Förster calculada em (cm) e em $(\AA)$ através da Eq. (4.2):

Tabela 1: Os valores da integral J e os raios de Förster para os respectivos filmes de PPV.

\begin{tabular}{|l|c|c|}
\hline \multicolumn{1}{|c|}{ Filmes } & $\mathbf{J}\left(\mathbf{M}^{-1} \mathbf{c m}^{-3}\right)$ & $\mathbf{R}_{\mathbf{0}}(\AA)$ \\
\hline Cast-PPV & $2,76 \times 10^{-10}$ & 44 \\
\hline Spin-PPV & $3,42 \times 10^{-9}$ & 67 \\
\hline Cast-PPV Estirado & $9,42 \times 10^{-9}$ & 60 \\
\hline LB-PPV & $4,40 \times 10^{-9}$ & 70 \\
\hline S.A-PPV Estirado & $9,69 \times 10^{-9}$ & 80 \\
\hline
\end{tabular}

Observa-se que embora o valor da distância crítica de Förster tenha variado para cada filme, os valores compreendem-se no intervalo de 10 a $100 \AA$ indicando que o processo de transferência pelo processo Förster é perfeitamente possível de ocorrer entre os segmentos conjugados dos filmes de PPV com diferentes ordenamentos moleculares. 
Capítulo 5

CONCLUSÃO 
O recém sucesso observado na área de dispositivos eletroluminescentes de filmes poliméricos ultrafinos (PLEDs - Polymer Light Emitting Diodes) vem motivando estudos que correlacionam a polarização da luz emitida por um polímero luminescente com a estrutura morfológica desses filmes. Tal resultado pode ser usado em dispositivos que codificam um sinal enviado, levando informações através da luz emitida.

Em vista disso, o objetivo deste trabalho foi a de contribuir para o estudo da influência do ordenamento molecular no estado de polarização da luz emitida por filmes poliméricos luminescentes. Neste caso, filmes de poli ( $p$-fenileno vinileno) (PPV) foram obtidos com diferentes ordenamentos moleculares de acordo com os processos de preparação (Casting, Spin-Coating (SC), Langmuir-Blodgett (LB) e Self-Assembly (S.A)) e também pelo processo de estiramento. Os filmes de PPV tiveram suas propriedades ópticas estudadas através das medidas de espectroscopia de absorção polarizada, fotoluminescência (PL) e do estudo da polarização da luz emitida utilizandose um aparato experimental exclusivamente para esse fim. Os resultados obtidos mostraram bastantes interessantes ao evidenciarem a influência da morfologia (ordenamento e empacotamento) molecular não somente no estado final de polarização da luz emitida, mas também no processo de transferência de energia entre moléculas.

O filme Cast-PPV apresentou propriedades ópticas de absorção e emissão típicas de um sistema desordenado (isotrópico). A medida do espectro de absorção da luz polarizada revelou que esse filme não apresentou anisotropia óptica na absorção, ou seja a luz foi igualmente absorvida pelos dois eixos principais da amostra (vertical e horizontal). Com a razão anisotrópica ( $\delta$ ) obtida igual a 1,0 logo se concluiu que as moléculas estão orientadas aleatoriamente e igualmente distribuídas em toda a área do plano do filme. A isotropia óptica também foi observada na emissão de luz polarizada pelo filme nas medidas de fotoluminescência (PL) polarizada, como mostrado pela Figura 4.4. $\mathrm{O}$ valor obtido para a anisotropia de emissão do filme Casting $\left(r=\left(\mathrm{I}_{\mathrm{V}}-\mathrm{I}_{\mathrm{H}}\right) /\right.$ $\left.\left(I_{V}+2 I_{H}\right)\right)$ no pico de zero-fônon foi de $\approx 0,1$. A relação entre a morfologia do filme e a polarização da luz emitida foi verificada com mais detalhes através da montagem experimental ilustrada no capítulo 3, item 3.2.3. De acordo com os resultados obtidos, o 
filme mostrou-se fracamente anisotrópico e conservou a direção de polarização entre a luz de excitação e a emitida. A hipótese proposta para explicar este comportamento baseou-se no conceito de transferência de energia entre moléculas do tipo Förster (dipolo-dipolo).

Para o filme Spin-PPV as medidas das propriedades ópticas de absorção e emissão mostraram que o filme assume um comportamento anisotrópico na emissão, apesar de não apresentar anisotropia óptica na absorção. $\mathrm{Na}$ medida de fotoluminescência polarizada, ao posicionar o polarizador $\left(\mathrm{P}_{1}\right)$ e analisador $\left(\mathrm{P}_{2}\right)$ paralelos um ao outro, o valor da intensidade de PL foi a mesma, não importando a direção dos polarizadores. Mas ao serem cruzados, a intensidade da emissão reduzia-se cerca de $60 \%$ do valor inicial. O valor obtido para a anisotropia de emissão $(r)$ foi de 0,18 . Observando os resultados da análise da polarização da luz emitida, o filme obtido apresentou um comportamento anisotrópico emitindo luz linearmente polarizada com a mesma direção da polarização da luz de excitação. Deste modo, conclui-se as moléculas do filme distribuídas ao longo do plano do filme estão orientadas na direção radial, imposto pelo processo de obtenção do filme. Explicou-se esses resultados usando os conceitos envolvidos no processo de transferência do tipo Förster.

Por outro lado, o filme Cast-PPV Estirado apresentou propriedades ópticas de absorção e emissão típicas de um sistema altamente ordenado (anisotrópico). De acordo com a medida de espectroscopia de absorção polarizada, o filme apresentou anisotropia óptica ao absorver 1,6 vez mais luz na direção do estiramento, do que na direção perpendicular. $\mathrm{O}$ valor da anisotropia de emissão $(r)$ calculado através da medida de fotoluminescência polarizada foi de 0,24 . Valor superior aos obtidos com os filmes de PPV obtidos por Casting $(r \approx 0,1)$ e por Spin-Coating $(r=0,18)$. Indicando que a luz emitida por esse filme é fortemente polarizada. Nos resultados da análise da luz emitida, verificou-se que independente da direção de polarização da luz incidente (paralela ou perpendicular à direção do estiramento), a luz emitida apresentava sempre polarização na direção do estiramento. Para obter uma explicação razoável para tal efeito foi necessário relacionar o mecanismo de transferência de energia tipo Förster, que provavelmente ocorreu entre as moléculas (doadoras e receptoras), com a morfologia do 
filme. Concluiu-se neste caso, que ao excitar menores segmentos conjugados orientados na direção da polarização da luz incidente, a energia é eficientemente transferida para cadeias de segmentos longos orientados na direção do estiramento $[37,42]$.

Filmes ultrafinos, com ordenamento molecular e baixo números de defeitos são características obtidas pela técnica de Langmuir-Blodgett (LB) [42]. As medidas ópticas realizadas neste trabalho confirmaram as características descritas acima para o filme LB-PPV. Na medida de espectroscopia de absorção polarizada, o filme mostrou-se altamente anisotrópico, apresentando uma razão anisotrópica de absorção ( $\delta$ ) de 3,6. Os resultados da medida de fotoluminescência polarizada mostraram que o filme possui as moléculas altamente ordenadas na direção de imersão (dipping), absorvendo e emitindo somente luz com polarização nesta direção, como se pode observar na Figura 4.16. O valor encontrado da anisotropia de emissão $(r)$ foi 0,5 o mais alto em relação aos valores encontrado para os filmes preparados pelas demais técnicas. Os resultados da análise da luz emitida mostraram que independente da direção de polarização da luz incidente a luz emitida pelo filme apresentou polarização na direção do estiramento. Os resultados observados sobre a luz emitida para os filmes ordenados foram em princípio inesperados, e pouco explorados na literatura. Neste caso também foi assumido o processo de transferência de energia tipo Förster como hipótese para explicar os resultados obtidos.

Por último estudou-se o comportamento óptico do filme S.A-PPV Estirado. Os resultados obtidos das propriedades ópticas de absorção e emissão foram análogos aos encontrados para o filme estirado obtido pelo método Casting. $\mathrm{Na}$ medida de espectroscopia de absorção polarizada, o filme apresentou uma forte anisotropia de absorção e de emissão na direção do estiramento caracterizado pela razão anisotrópica ( $\delta$ ) que foi de 1,5 e pelo valor da anisotropia de emissão $(r)$ calculado através da medida de fotoluminescência polarizada que foi de 0,25 . Os resultados da análise da luz emitida mostraram, assim como nos demais filmes orientados, que independente da direção de polarização da luz incidente o filme emitiu luz com polarização sempre na direção do estiramento. A hipótese para explicar este fenômeno se baseia no fato de que, a energia é 
eficientemente transferida do segmento conjugado mais curto para o mais longo, sendo esses últimos orientados na direção do estiramento.

Portanto, as principais contribuições dessa dissertação resumem-se a:

1. Fabricação de filmes altamente ordenados por diferentes técnicas, como estiramento;

2. Análise da polarização da luz emitida dos filmes luminescentes e a correlação com o ordenamento molecular;

3. Estudo da polarização da luz emitida considerando o mecanismo de transferência de energia proposto por Förster, e o cálculo do raio crítico de Förster para filmes de PPV obtidos por técnicas diferentes;

Como contribuições para trabalhos futuros sugere-se:

1. Filmes de PPV obtidos com diferentes espessuras e diferentes taxas de estiramentos, com objetivo de verificar com detalhes o processo de transferência envolvido;

2. Análise de componente circularmente polarizadas da luz emitida em filmes de diferentes graus de ordenamento;

3. Estudo da polarização da luz emitida em dispositivos eletroluminescentes (PLEDs). 


\section{Anexos}

Abaixo estão os gráficos da superposição do espectro da luminescência e do espectro da absorção para o filme de PPV obtido por Casting (A), por Spin-Coating (B), Langmuir-Blodgett (C), Casting com estiramento (D) e Self-Assembly (E), respectivamente, utilizados no cálculo da integral $\mathrm{J}$.
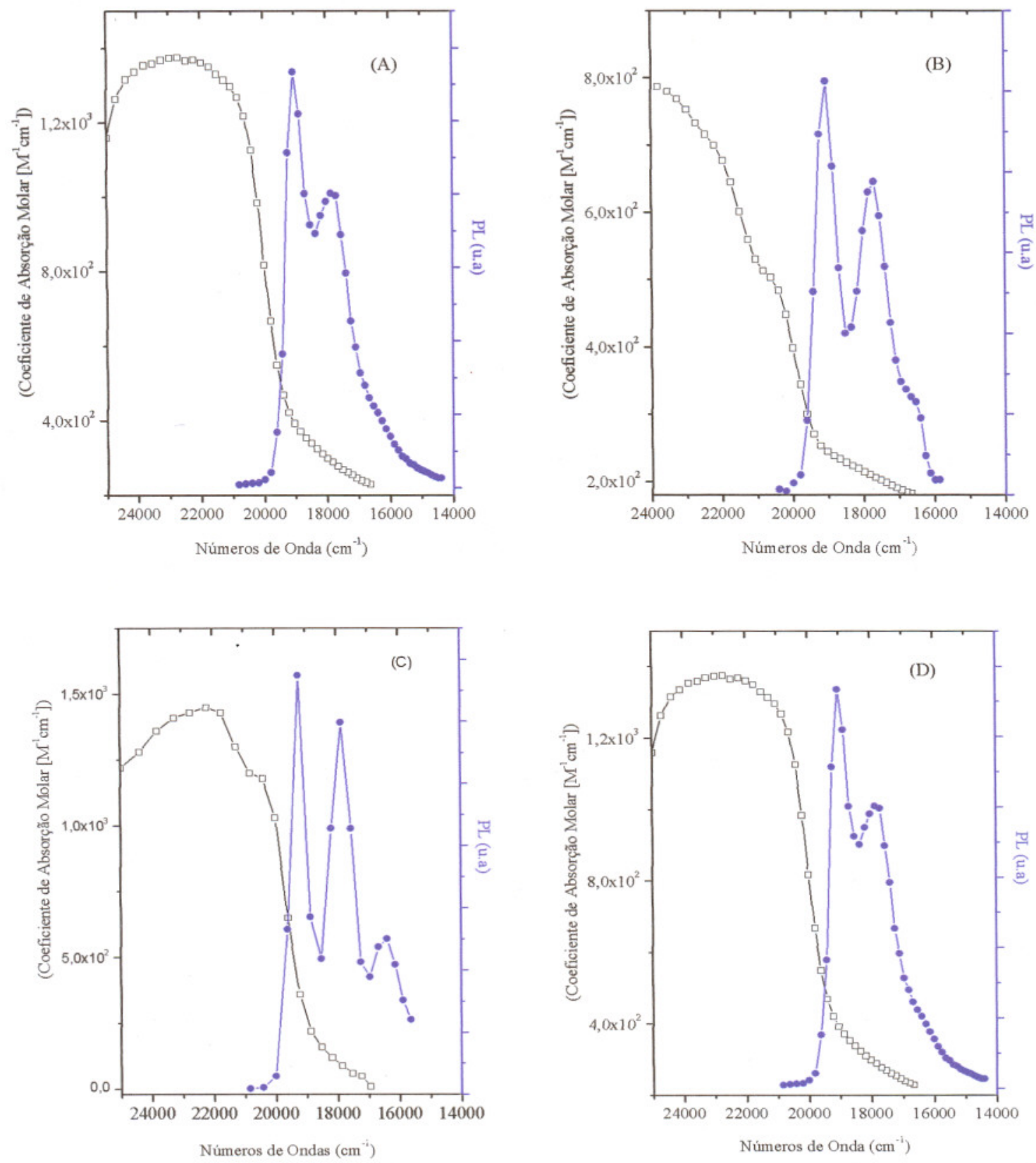


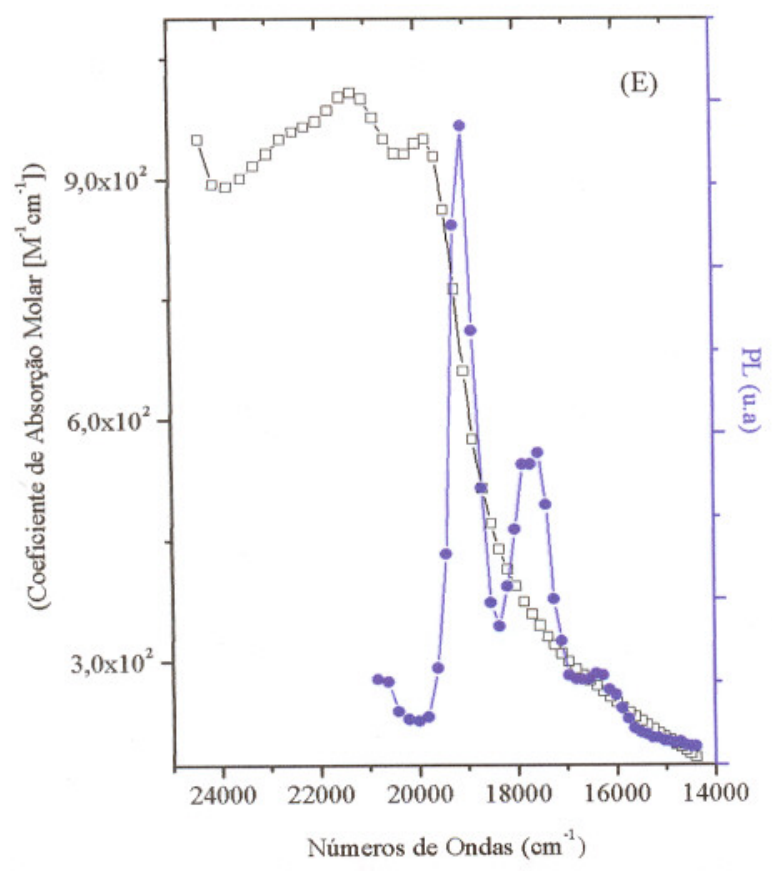

